


\section{GEISEL LIRRARY \\ UNIVIRSITY OF CALIFORNIA, SAN DIEGO \\ UA JOLLA, CALIFORNIA}


New York now offers more Free Public Education in Natural Science than any other city

\title{
GUIDE TO THE
}

NATURE TREASURES OF NEW YORK CITY

AMERICAN MUSEUM OF NATURAL HISTORY NEW YORK AQUARIUM

NEW YORK ZOÖLOGICAL PARK AND BOTANICAL GARDEN

\section{BROOKLYN MUSEUM, BOTANIC GARDEN AND CHILDREN'S MUSEUM}

\author{
PREPARED BY \\ GEORGE N. PINDAR
}

ASSISTED BY

MABEL H. PEARSON AND G. CLYDE FISHER

PUBLISHED FOR THE

American Museum of Natural History BY

CHARLES SCRIBNER'S SONS 
Copyright, 1917, by

The American Museum of Natural History 


\section{PREFACE}

THE purpose of this Guide, which owes its idea and inception to President Henry Fairfield Osborn of the American Museum of Natural History, is to render accessible under one cover an account of the public scientific institutions of New York City which are built and supported by public funds in coöperation with the benefaction and direction of individual citizens. This union of municipal and private endeavor in the cause of Public Education is unique.

The Guide is designed to be brief enough to permit of easy reading and at the same time sufficiently detailed and descriptive to give an adequate idea of the collections these institutions contain and of their importance as educational factors. The visitor is thus enabled to choose from the exhibits of any or all of the Museums, Parks and Gardens those in which he is most interested and to proceed directly to them, or to plan a survey as a whole with a minimum waste of time and effort. Rearrangements of the collections which are liable to take place in the near future have been anticipated as far as possible at the time of writing. 


\section{PREFACE}

Acknowledgments are due to Mr. Madison Grant, Dr. W. T. Hornaday and Dr. Charles H. Townsend of the New York Zoölogical Society; to Dr. N. L. Britton of the New York Botanical Garden; to Director W. H. Fox and the Curators of the Brooklyn Museum; to Dr. C. Stuart Gager of the Brooklyn Botanic Garden; to Miss Anna B. Gallup of the Children's Museum of Brooklyn, and to the President, Director and Curators of the American Museum of Natural History for their helpful suggestions and cordial coöperation in the work, as well as to Miss Clara M. Beale of the American Museum of Natural History, who has been good enough to read all the proof.

G. N.P.

December, 1916. 


\section{CONTENTS}

PAGE

MANHATTAN

American Museum of Natural History . . . . 1

New York Aquarium . . . . . . . . . . . 133

BRONX

New York Zoölogical Park . . . . . . . 147

New York Botanical Garden . . . . . . . 177

BROOKLYN

Brooklyn Museum . . . . . . . . . . 193

Brooklyn Botanic Garden . . . . . . . . 257

Children's Museum . . . . . . . . . 265 



\section{MAPS AND ILLUSTRATIONS}

PAGE

American Museum of Natural History . . Frontispiece Lower Manhattan (Map) . . . . . . . . . 3

American Museum of Natural History "Willamette" Meteorite . . . . . . . . . 6 First Floor Plan . . . . . . . . . . . . . 7 Flowering Dogwood and Wild Plum . . . . 10 Specimens and Glass Models of Invertebrates . . . 13 ,Eskimo and Northwest Coast Groups and Specimens . 18 Iroquois Indian Group . . . . . . . . . 23 Arapaho Indian Dancer and Dakota Indian Girl . 32 Pueblo Pottery . . . . . . . . . . . 41

Wolverene, Moose, Polar Bear, Virginia Deer . . . . 44 Second Floor Plan . . . . . . . . . . 45 Extinct Birds . . . . . . . . . . . . 51

Sharks, Paddlefish, Deep-sea Fish . . . . . 56 Mexican and Central American Sculptures . . . . 60 African Village Scene and Specimens . . . . . 65 
PAGE

Third Floor Plan . . . . . . . . . . . . 67

Coati, Aard-vark, Skunk and Colobus Monkey . $\quad 72$

Duck Hawk and California Condor . . . . . . 75

Brown Pelican, Egret and Whooping Crane . . . 81

Peruvian Mummies and Pottery, Stone Seat from

Ecuador . . . . . . . . . . . . 88

Chinese Cloisonné . . . . . . . . . . . . . 92

Chinese Bronzes, God of Mercy . . . . . . . 94

Shells . . . . . . . . . . . . . . 96

Tyrannosaurus and Asphalt Group . . . . . . 98

Fourth Floor Plan . . . . . . . . . . . . . . 99

Uintatherium and Eohippus . . . . . . . . 101

Brontosaurus, Smilodon and Warren Mastodon . . 105

Ground Sloth . . . . . . . . . . . . 110

Geological Specimens . . . . . . . . . 114

Jade, Cameo and Quartz Specimens . . . . . 118

Mineral Specimens . . . . . . . . . . 120

Tahitian Fire Walker and Maori Warrior . . . . 123

Igorot and Bagobo Specimens, and Igorot Weaver

Group . . . . . . . . . . . . 125

Moro Weapons . . . . . . . . . . . 128

New York Aquarium

Interior . . . . . . . . . . . . . 134

Mudfish, Spadefish, Spider Crab and Fulgur . . . 137 


\section{MAPS AND ILLUSTRATIONS}

PAGE

Crappie, Starfish, Gars and Sturgeon . . . . 140

Porkfish, Sea Horses and Mud Puppy . . . . . 143

NEW YORK ZOÖLOGICAL PARK

Upper Manhattan and Bronx (Map) . . . . . 145

Italian Gardens and Seal Pool, Baird Court . 146

Ground Plan . . . . . . . . . . . . 150

Elk Herd, Elephant House and Rocking Stone . . . 155

Monkeys, Chimpanzees, Orang-utan and Lion Cubs . 160

Alligator Pool, Gavial and Elephants . . . . 169

Flying Cage, Lake Agassiz and Bear Dens . . . . 174

\section{New York Botanical Garden}

Museum, Conservatory and Pinetum . . . . 178

Ground Plan . . . . . . . . . . . 181

Rhododendron Banks and Herbaceous Gardens . 187

\section{BROOKLYN MUSEUM}

Brooklyn (Map) . . . . . . . . . . . 192

Museum Building . . . . . . . . . . 194

Japanese Armor and Image of Buddha . . . . . 204 Image, Helmet and Bronze Head . . . . . . 210 Chinese Cloisonné . . . . . . . . . . 214

Zuñi, Apache and Navajo Indian Specimens . . . 221 


\section{MAPS AND ILLUSTRATIONS}

PAGE

Coral Reef . . . . . . . . . . . . . 230

Bald Eagle, Cape Birds and Deer . . . . . . 245

Bird Groups . . . . . . . . . . . . 250

\section{Botanic Garden}

Administration Building and Conservatories . . . 256 Japanese Garden . . . . . . . . . . . 261

Children's Museum

Museum and Wireless Room . . . . . . . . 264

Geographical Groups . . . . . . . . . 267 


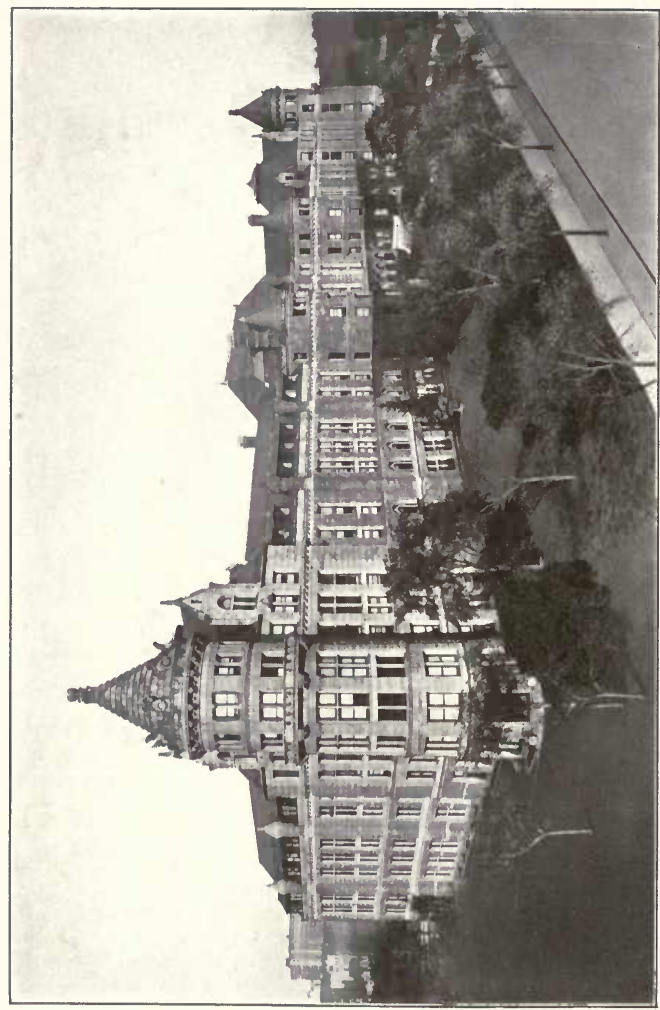

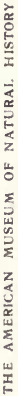




\section{THE AMERICAN MUSEUM OF NATURAL HISTORY}

7 HE American Museum of Natural History was founded * and incorporated in 1869 for the purpose

1 of establishing a Museum and Library of Natural History; of encouraging and developing the study of Natural Science; of advancing the general knowledge of kindred subjects, and to that end of furnishing popular instruction. For eight years its home was in the Arsenal in Central Park. The corner-stone of the present building in Manhattan Square was laid in 1874 by President U. S. Grant.

The Museum is located at 77 th Street and Central Park West and can be reached by the Eighth or Ninth Avenue surface cars, the Sixth or Ninth Avenue elevated to $81 \mathrm{st}$ Street station, or by the subway to 72 nd or 79 th Street sta-

* The following were the founders of the Museum: William T. Blodgett, Joseph H. Choate, Robert Colgate, Charles A. Dana, A. G. Phelps Dodge, Benjamin H. Field, William A. Haines, Adrian Iselin, Morris K. Jesup, J. Pierpont Morgan, Henry Parish, Howard Potter, Theodore Roosevelt, Benjamin B. Sherman, D. Jackson Steward, Robert L. Stuart, John David Wolfe. 


\section{THE AMERICAN MUSEUM OF NATURAL HISTORY}

tion. The Museum is open free every day in the year: on week days from 9 A.M. to 5 P.M., on Sundays from 1 to 5 P.M.

The Museum is under the control of a self-perpetuating Board of Trustees, which includes the Mayor, the Comptroller and the President of the Department of Parks, ex officio. This Board has the entire direction of all the activities of the Museum, as well as the guardianship of the collections and exhibits.

All the collections in the exhibition halls and in the study rooms are the gifts of the Trustees, Members and other friends and supporters of the institution. The funds which enable the Trustees to purchase specimens, to carry on explorations in various parts of the world, to prepare and publish scientific papers and to enlarge the library are raised by contributions from the Trustees, Members and other friends. These contributions are divided into three classes: (1) the Endowment Fund, (2) the Membership Fund, (3) voluntary subscriptions. The Membership Fund, derived from the subscriptions of Members, ${ }^{*}$ is of par-

* Associate Members (restricted to persons living more

than 50 miles from New York City) (annually) Annual Members . . . . . . (annually)

Sustaining Members . . . . . (annually)

Life Members

Fellows

Patrons

Associate Benefactors .

Associate Founders

Benefactors.

$\$ 3$
10
25
100
500
1,000
10,000
25,000
50,000




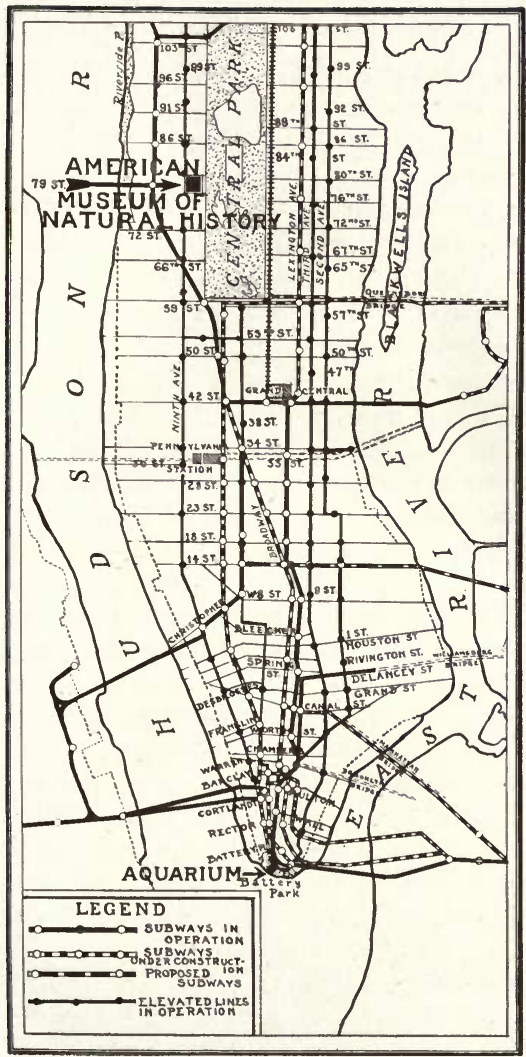




\section{THE AMERICAN MUSEUM OF NATURAL HISTORY}

ticular importance in the educational work of the Museum. Voluntary contributions may be used for general purposes or for such particular object as the donor may specify; some of the most important and valuable collections have been obtained through such gifts.

The Museum building is erected by the City of New York. It is one of the largest municipal structures in the city and has cost approximately $\$ 5,318,820$.

The building, of which eight sections have been completed, will cover the entire area of Manhattan Square. The first section was erected in 1874-1877. The present South Façade is 710 feet in length from tower to tower. Eastern, western, and northern façades, comparable with this in length, are planned for the completed structure, which will be larger than any building in the world to-day, even the Escorial of Spain or the Capitol at Washington. The total area of the floor space is 470,789 square feet, or about eleven acres, of which 271,886 square feet are open to the public.

The City makes an annual appropriation, known as the Maintenance Fund, which is devoted to the heating, lighting, repairing and supervising of the building, the care of the collections, the construction of cases and other maintenance work. This fund in 1915 amounted to $\$ 200,000$. The Trustees also contribute to the Maintenance Fund annually in amounts varying from $\$ 50,000$ to $\$ 100,000$, inasmuch as the municipal appropriation is inadequate thoroughly to maintain the building. 
Under the arched entrance way to the Museum, on 77 th Street, the visitor first notices a bench-mark established by the U. S. Geological Survey in 1911, indicating the latitude and longitude and the height above sea level (eighty-six feet). On the right is a pot-hole from St. Lawrence County, New York, two feet across and four feet deep. The hole was formed by pebbles whirled in an eddy of a stream beneath the melting ice of the glacier that once covered New York State. To the left is a large slab of fossiliferous limestone from Kelley's Island, in Lake Erie near Sandusky, Ohio, whose surface has been smoothed, grooved and scratched by the stones and sand in the bottom of the immense ice sheet that covered this part of our country during the glacial period. Geologists tell us that 30,000 to 50,000 years ago this entire section was covered by ice which was moving in a southerly direction.

Entering the Museum the visitor finds at the left and right the Information Bureau and Visitors' Room. Wheel chairs for children or adults may be obtained here without charge. Postcards, photographs, guide leaflets and the publications of the Museum are on sale, and here one may also arrange to meet friends. A Restaurant is located in the basement. 


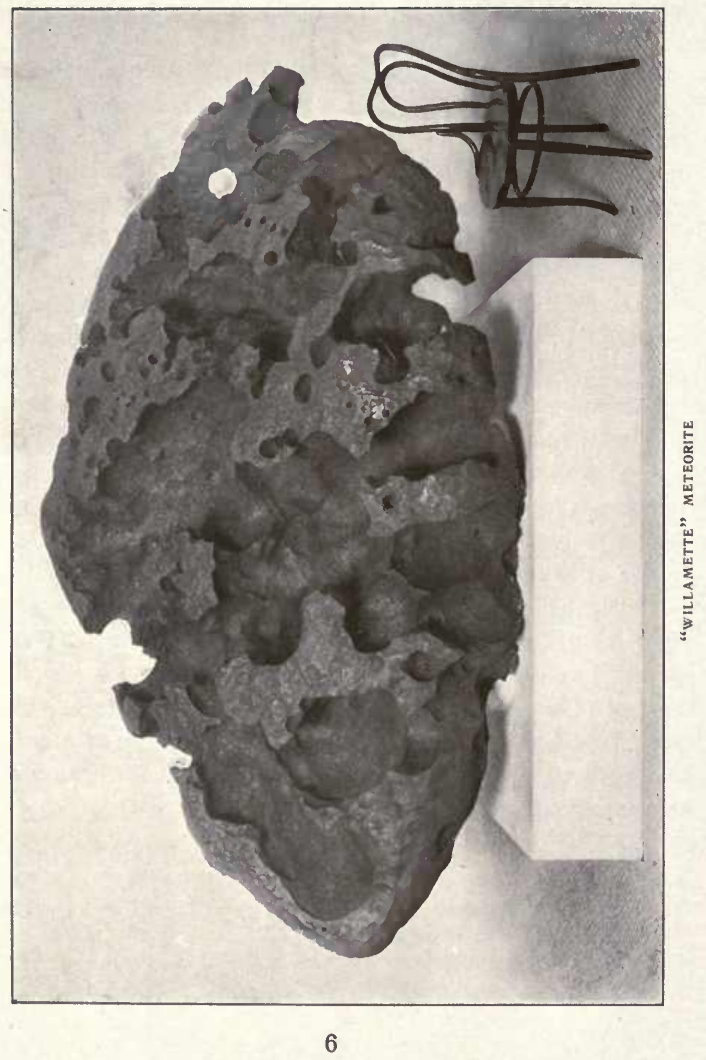




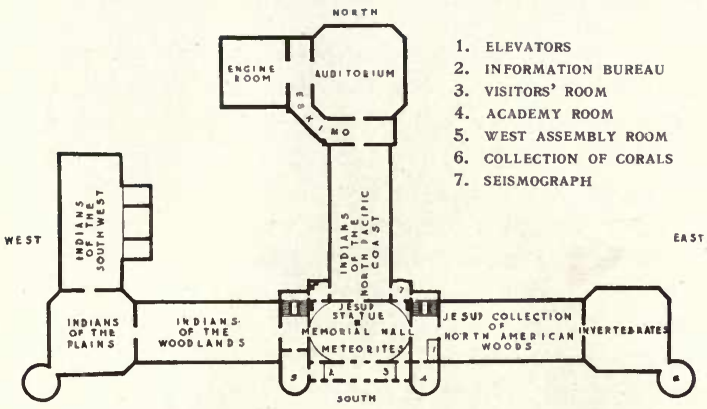

\title{
FIRST FLOOR
}

\section{SOUTH PAVILION}

\author{
"men of mould, \\ Well embodied, well ensouled."
}

Emerson.

From the lobby the visitor enters Memorial Hall, an oblong room of quiet impressiveness, with wall niches containing the marble busts * of noteworthy pioneers of American science, the gift of Morris K. Jesup, a founder, trustee and benefactor of the Museum and for twenty-seven years its President. The marble statue of Mr. Jesup has been

* These include Benjamin Franklin, statesman and natural philosopher; Alexander von Humboldt, geographer and geologist; Louis Agassiz, zoölogist; Joseph Henry, physicist; John James Audubon, ornithologist; Spencer Fullerton Baird, zoölo- 


\section{THE AMERICAN MUSEUM OF NATURAL HISTORY}

erected by the Trustees and a few other friends, in recognition of his munificent benefactions to the institution.

Circling this same hall is a portion of the Museum's collection of meteorites, ${ }^{1}$ popularly known as shooting stars, ranging in weight from a few pounds to thirty-six tons. The greater number of meteorites are stony, but the more interesting are composed chiefly of iron, while certain of them contain both stone and iron. The toughness of iron meteorites is due to the presence of nickel, and the fact that they were so difficult to cut led to the adoption of an alloy of nickel and iron in making the armor plate for battleships. Meteorites have a very definite structure and when polished(see specimen on the right with electric lamp) show characteristic lines which together with their composition are, to the expert, absolute proof that the specimens are meteorites.

"Ahnighito," or "The Tent," at the left, is the largest known meteorite and was brought from Cape York, Greenland, by Rear Admiral Peary. It weighs thirty-six and one half tons, and its transportation to New York was an engineering feat. Opposite, at the right, is the curiously pitted "Willamette" meteorite from Oregon. The smaller meteorites will be found in the Hall of Geology, fourth floor.

gist and founder of the United States Fish Commission; James Dwight Dana, geologist; John Torrey, botanist; Edward Drinker Cope, palæontologist; Joseph Leidy, anatomist, and Robert E. Peary, explorer.

1 The Meteorites in the Foyer of the American Museum of Natural History -.10 . 


\section{THE AMERICAN MUSEUM OF NATURAL HISTORY}

The visitor's tour of the Museum must depend entirely on the time he has at his disposal. If it is his intention to visit but one hall devoted to a particular branch of science, it would be well to consult the Directory facing the elevators on the first floor of the Museum. Otherwise it is best to refer to the floor plans in this Guide.

\section{EAST CORRIDOR}

Leaving the statue on the left and the "Willamette" meteorite on the right, the visitor proceeds east and enters the East Corridor, where the elevators and a Directory of the building are located. Here will be found maps of the north and south polar regions showing the routes of explorers. On the wall by the north polar map is the sledge used by Admiral Peary in his last expedition in search of the north pole and also one of the sledges used by Amundsen in his journey to the south pole. A study of these sledges readily shows the differences in construction followed by these successful explorers. Thence we enter the

\section{SOUTHEAST WING}

\section{Hall of North American Forestry \\ "The groves were God's first temples, ere man learned To hew the shaft, and lay the architrave."}

Bryant.

This hall contains the Morris $\mathrm{K}$. Jesup Collection of North American Woods, a collection designed for the stu- 


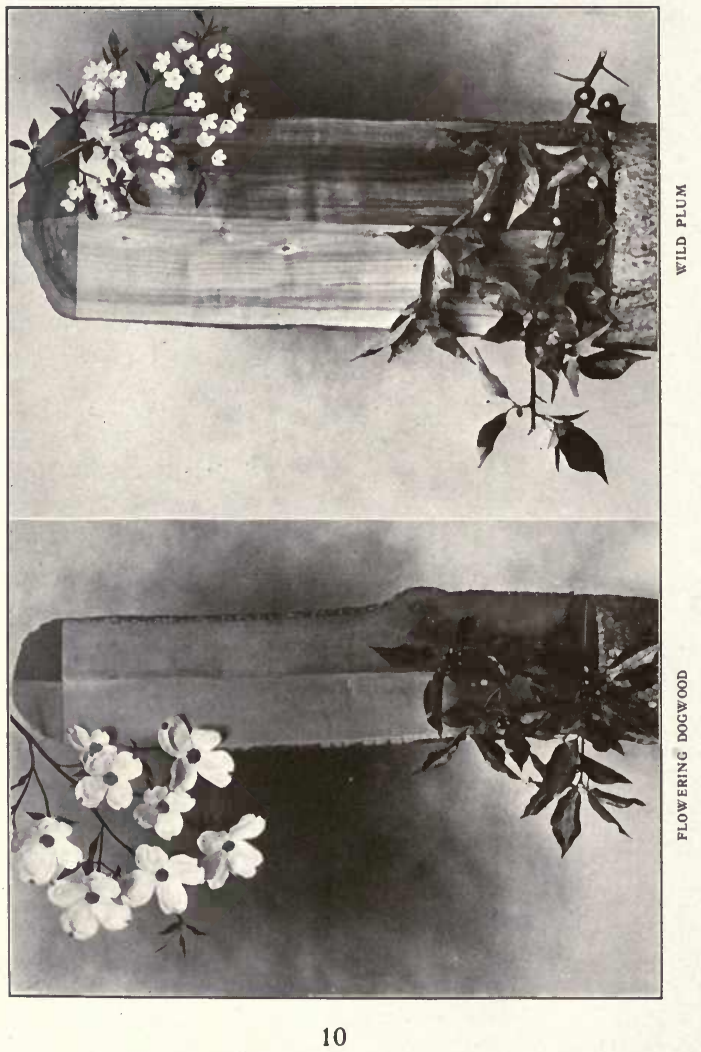


dent, artisan and forester, those interested commercially as well as those desiring to increase their knowledge of the woodland. In its completeness and attractiveness, its scientific correctness and educational value, the collection is a splendid example of what such an exhibition should be.

The collection was begun by Mr. Jesup in 1880, and throughout his entire presidency it received his constant attention. In its perfected condition it displays in related groups or families more than five hundred species of North American trees. Each tree is represented by a section of trunk, five feet high, cut lengthwise radially two and one quarter feet, the cut surface showing the color and graining of the quartered lumber in its natural and polished state. Accompanying many of the specimens are wax models of leaves, ${ }^{2}$ flowers and fruit. Attention is called particularly to the flowers of the decorative magnolias, of the basswood, interesting to bee keepers, to the curious fruits of the sassafras, persimmon and Osage orange and to the autumn foliage of oak, sweet gum and sumach.

The most conspicuous specimen is a section of the Big Tree, "Mark Twain" (Sequoia washingtoniana), cut about twelve feet from the base. The section is sixteen and one half feet in diameter, and according to the annual rings was 1341 years old when cut down in the autumn of 1891 .

2 Plant Forms in Wax-.10.

${ }^{3}$ The Big Tree and its Story -.10 


\section{THE AMERICAN MUSEUM OF NATURAL HISTORY}

\section{SOUTHEAST PAVILION}

\section{INVERTEBRATES}

\section{"And God said, Let the waters bring forth abundantly the moving creature that hath life." \\ Genesis.}

The specimens in this room are chiefly Invertebrates. In the foreground is the bronze bust of Darwin presented by the New York Academy of Sciences to the Museum on the occasion of the Darwin Centenary in 1909, at which time this pavilion was designated as the Darwin Hall. The installation in the Alcoves is designed to give a synopsis of the animal kingdom and the relationships between the various groups, while the special exhibits, in other portions of the hall, are intended to illustrate certain biological principles. The visitor, passing around the hall from left to right, finds that the progression is from the lowest forms of animal life to the highest and most complex, i.e., from the Protozoa to the Primates, including Man. Many of the invertebrates, particularly the lowest forms, are so minute that they can be seen only by the aid of a compound microscope. In these instances the specimens are represented by models in glass and wax, many times enlarged.

Alcove 1-Protozoa. This group contains the lowest forms of animal life. They are all single-celled individuals, some being found in swamps and stagnant water and others in the ocean. 


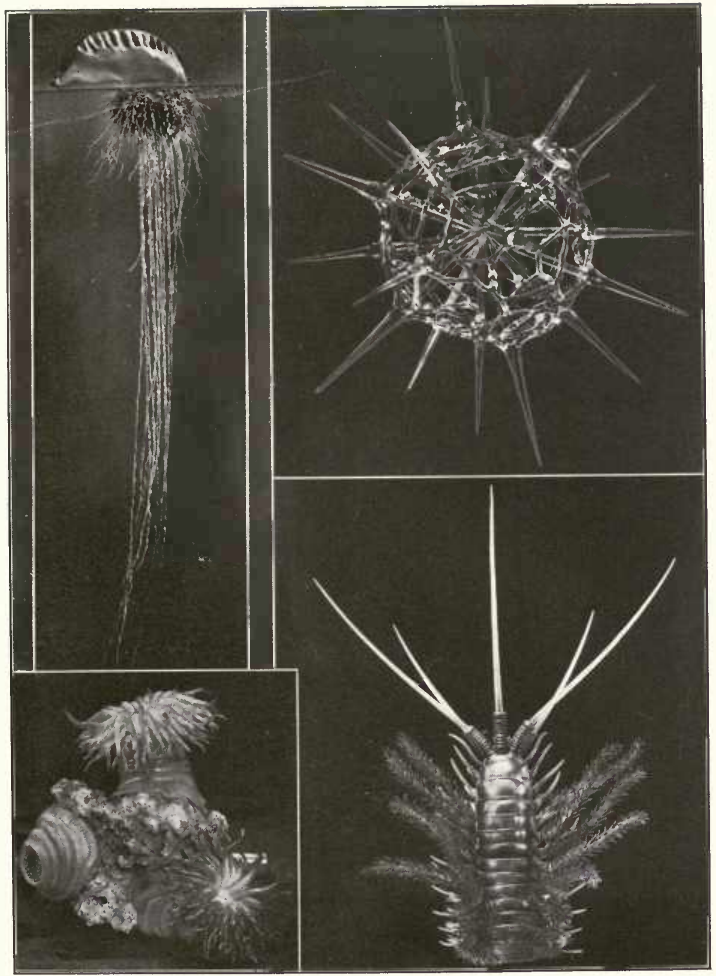

PORTUGUESE MAN-OF-WAR SEA ANEMONE
RADIOLARIAN

PLUMED WORM 


\section{THE AMERICAN MUSEUM OF NATURAL HISTORY}

Alcove 2-Sponges. Many of the "glass" sponges are exceedingly beautiful; certain other specimens are coated with wax, tinted to show the natural color of the flesh of the animal.

Alcove 3-Polyps. Here are shown the coral animals and their relatives; plant-like hydroids, frequently mistaken for seaweeds; jelly-fishes, brilliantly colored sea anemones, sea fans and sea plumes, reef corals and the precious coral of commerce. In front of the window is a life-size model in glass of the beautiful Portuguese man-of-war.

Alcove 4-Flatworms, the best known species of which include the tapeworms. There are also exhibited parasitic and free-living flatworms, the latter, which inhabit both salt and fresh water, being shown by enlarged models in the right-hand alcove case. These in particular well illustrate the great diversity of color and detail found in this group.

Alcove 5-Roundworms. Here may be found an enlarged model of the common roundworm, or stomach worm of the horse (Ascaris), showing the internal structure.

Alcove 6-Rotifers. These are minute wheel animalcules, comprising many exquisite and grotesque forms. They are aquatic and found mainly in fresh water.

Alcove 7-Sea mats, minute plant-like or encrusting animals which lead the colonial form of life, and the lamp shells, which superficially resemble clams but by structure are more closely related to the worms and starfishes.

Alcove 8-Sea stars, the pest of the oyster beds; brittle 
stars, so called because of their tendency to drop one or more arms when handled; sea cucumbers and sea lilies, also sea urchins, which form an important article of food in Europe and the West Indies.

Alcove 9-Annulates, worms whose bodies are made up of rings or segments. They inhabit both salt and fresh water. A number of them are illustrated by a series of enlarged models. The houses that these annulates build are frequently beautiful and interesting.

In the window is a group showing a section of a mud-flat on the New England coast, which graphically depicts the variety, habits and life of marine worms.

Alcove 10-Arthropods, which include the familiar crabs, lobsters, insects and their relatives. The case in the center of the alcove contains a model showing the anatomy of the common lobster, also enlarged models showing the heads of various insects. On the wall are the two largest specimens of lobster (weighing thirty-one and thirty-four pounds respectively) that have ever been taken. The largest of the arthropods is the giant spider-crab of Japan, which has a spread of about ten feet.

Alcove 11-Mollusks. The exhibit includes marine, fresh-water and land animals. Special attention should be given to the enlarged models of the common clam and oyster, displayed in the center case. Other collections of mollusks will be found on the third floor.

Alcove 12-Chordates, including vertebrates. The ver- 


\section{THE AMERICAN MUSEUM OF NATURAL HISTORY}

tebrates include the largest and most intelligent animals, culminating in Man, who still bears witness to his chordate ancestry in the reappearance of a chorda (cartilaginous spine) and gill clefts during embryonic life. In this section are specimens of the lancelet Amphioxus, related to the primitive group from which the vertebrates developed.

The visitor should now go to the Tower Alcove which contains a comprehensive synoptic series of stony corals. $R e$ turn to the center of the hall and examine the four large models of the malaria mosquito, enlarged seventy-five diameters or in volume 400,000 times the natural size.

In the windows around the hall are the Sea Worm, ${ }^{4}$ Shore Mollusk and Wharf Pile Groups, ${ }^{5}$ the last-named being a reproduction of the piles of an old wharf at Vineyard Haven, Massachusetts, and the varied and countless marine invertebrates which adhere to them below the water line.

In other portions of the hall will be found exhibits to illustrate certain facts made clear by Darwin and those who follow him: on the left, facing the entrance, Variation under Domestication, and on the right, Variation in Nature. The Struggle for Existence is portrayed by the meadow mouse surrounded by its many enemies, while the simpler features of the Mendelian Laws of Heredity ${ }^{6}$ are illustrated by the exhibits showing the inheritance of color in the common and sweet pea, and in a series of panels in a

${ }^{4}$ The Sea Worm Group-.10. ${ }^{5}$ The Wharf Pile Group-.10.

${ }^{\circ}$ Heredity and Sex-.10. 


\section{THE AMERICAN MUSEUM OF NATURAL HISTORY}

neighboring case showing the inheritance of coat-color in rats. Now return to the East Corridor, turn to the right, and underneath the stairway on the left enter

A small room where the visitor will find the large Mainka Seismograph for recording earthquakes. This instrument was the gift of Emerson McMillin to the New York Academy of Sciences, and was deposited in the Museum by the Academy. Just beyond and north of Memorial Hall is the

\section{SOUTH CENTRAL WING}

\section{Indians of the North Pacific Coast}

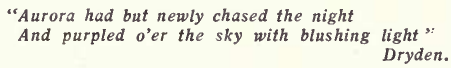

Here are displayed specimens illustrating the culture of the Indians of the Northwest Coast of America and also of the Eskimo.

The most conspicuous object is the Haida canoe in the center of the hall. In it are figures representing a party of Chilkat Indians on their way to a potlatch. In the stern stands the chief, or medicine man, who is in charge of the ceremony. The canoe is a huge dugout made from a single tree; it is sixty-four feet long and eight feet wide. Immediately north of it will be found groups illustrating the home life and pursuits of the Kwakiutl Indians. Placed against the pillars and walls of the hall are many grotesquely 


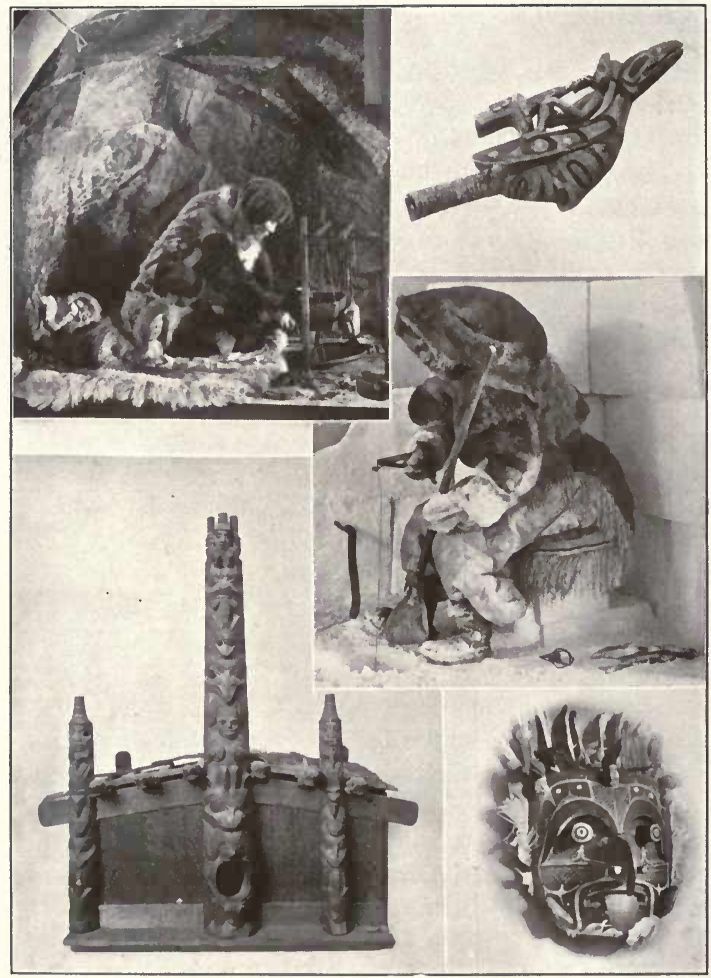

INTERIOR ESKIMO IGLOO NORTHWEST COAST HOUSE
SHAMAN'S RATTLE ESKIMO WOMAN FISHING SHAMAN'S MASK 


\section{THE AMERICAN MUSEUM OF NATURAL HISTORY}

carved house posts and totem poles. In some instances the carvings represent the coat of arms or the family tree, or illustrate a story or legend connected with the family.

The collections in this hall run from south to north; those on the east, or right-hand side, are from the Indians of the Interior; those on the west, or left-hand side, are from the Coast and Island Indians. The visitor is advised to begin at the lower right-hand side. Begin then with the

Thompson River Indians. This collection includes a valuable series of baskets, noteworthy for its uniqueness of design and complexity of weaving. These peoples generally wore clothing of buckskin. The visitor will be interested in a group which illustrates members of the tribe engaged in tanning skins. Hunting and ceremonial objects also will prove of interest.

At the end of the next alcove will be found a collection from the Coast Salish, comprising articles of dress, basketry and ceremonial objects. The most conspicuous object, however, is a large blanket woven of goat's wool together with a primitive loom and other implements used in weaving. Proceed to the

Bella Coola group and examine the numerous ceremonial masks representing the deities of these peoples and the articles woven of spruce bark, used in their ceremonials, hunting and fishing implements and a series of dried fish used for food. Entering the section devoted to the

Tsimshian, there is displayed a series of masks and rattles used in various ceremonials by the medicine men, or 


\section{THE AMERICAN MUSEUM OF NATURAL HISTORY}

shamans. These masks differ from those of other tribes in being decorated with weasel skins and abalone shell. Note the articles of dress which are ornamented with the teeth and dewclaws of mammals. Continue to the

Haida exhibit and view the specimens used in the household, in fishing and in ceremonials. In the central case will be found a number of models of canoes and whalebone implements used in the preparation of cedar bark, which is used for garments, basketry and the sails of boats. In another case will be found a number of slate dishes carved with designs of animals and sea monsters, and in other places may be seen a number of masks and models of totem poles. Entering the corridor at the north end of the group, one finds the collections devoted to an exposition of

Eskimo life. Finely etched and carved pieces of ivory and crude but effective implements of the sea and chase predominate. Well-executed groups, representing the everyday life of these peoples, are installed in prominent positions. At the end of the corridor on the right is a collection of the principal building stones of the United States. $R e$ turn to the main hall, and on the right inspect the collections devoted to the

Tlingit, Kwakiutl and Nootka Indians respectively. The material from these peoples, it will be noted, is much finer in its technique than that from the other groups represented in this hall. Special attention is directed to the large collection of elaborately woven baskets in the Tlingit section, which are used in the household occupations of these peo- 


\section{THE AMERICAN MUSEUM OF NATURAL HISTORY}

ples, to the wonderful examples of Chilkat blankets, woven from mountain goat's wool and cedar bark, and to the curiously formed and carved spoons of mountain goat horn in the same section. The conventionalized designs engraved on wooden boxes are worthy of inspection, as are also the pipes, masks and carvers' tools.

Examine the cases containing the raw material, implements and finished product, which illustrate the weaving art of the Kwakiutl, and also the models of the primitive but effective traps used in fishing by these same peoples. In a near-by alcove the curiously designed whaling implements, seal clubs and fishing tackle of the Nootka are noteworthy. It is related that when Europeans first visited the Pacific Coast they found that the Nootka were the only people who attempted the hunting of whales and that it was the privilege and duty of the chiefs to throw the harpoon. The basketry work in this hall is frequently used by artists and designers as patterns for symmetry and decoration.

The industries and ceremonies of the various tribes are faithfully reproduced in the mural decorations. The visitor now proceeds to the

\section{WEST CORRIDOR}

where are exhibited specimens of particular interest recently acquired. A large relief map of the Panama Canal Zone and the series of paintings of Mont Pelé are of interest. 


\section{THE AMERICAN MUSEUM OF NATURAL HISTORY}

On the first landing of the stairway is the William Demuth Collection of Pipes and Fire-making Appliances from various countries. Beyond is the

\section{SOUTHWEST WING}

\section{INDIANS OF THE WOODLANDS}

"To western woods, and lonely planns,

Where Nature's wildest genins reigns."

Freneau.

Most of the specimens shown in this hall* were collected from Indians who formerly lived or who now reside east of the Mississippi River and south of the Great Lakes, a large section being devoted to the Iroquois-those Indians who were directly connected with the early history of the colonies.

The confederation of Iroquoian tribes, comprising the Mohawk, Seneca, Oneida, Onondaga and Cayuga, known in history among other names by that of the Five Nations, undoubtedly constituted the largest and most powerful organization ever instituted among natives of this land. Later

* The cases on the north side of this hall have been grouped to show the life of the Indians of the Middle Atlantic States and the Southeastern Area, while those on the south side of the hall illustrate the culture of the Indians of New England and Eastern Canada. 


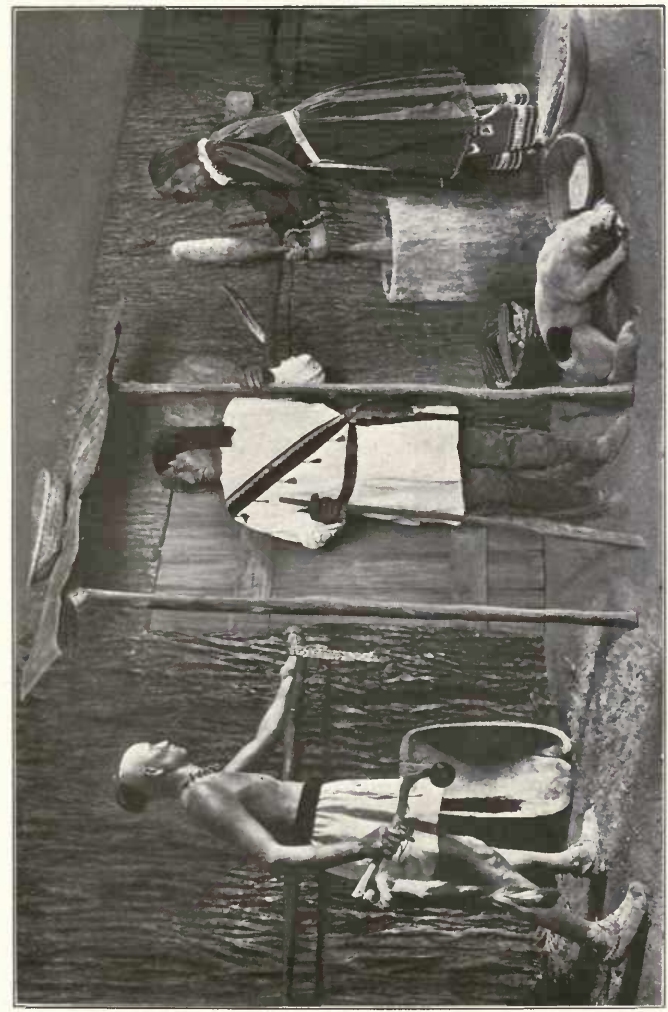

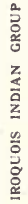




\section{THE AMERICAN MUSEUM OF NATURAL HISTORY}

the Tuscarora joined the league of the Iroquois, or the Five Nations, and it then became known as the Six Nations. This league was formed about 1534 for the primary purpose of securing peace and welfare by the enforcement of the forms of civil government. The leaders were astute diplomats, as the French and English statesmen of those days frequently discovered. The Iroquoian tribes were sedentary and agricultural people, depending for only a small part of their subsistence upon trophies of the chase.

The first wall case on the right contains an interesting group depicting the home life of an Iroquois family. The chief, in the center, is about to receive a wampum message from an Indian runner. This runner carries in one hand a war club, such as was used by these peoples, and in the other a string of wampum. The woman is engaged in a household pursuit-grinding maize by means of the primitive mortar and pestle.

Other portions of the Iroquois section contain a display of articles used in the household, consisting of dishes, platters, mortars, pestles, spoons of wood, and basketry, together with implements of stone and bone. Their method of carrying children when traveling is shown by a number of baby carriers; their fine arts are illustrated by an excellent collection of silver ornaments including the implements used in their manufacture. Ceremonials are portrayed by a collection of grotesque masks and a series of rattles used by the members of the False Face Societies. Excellent specimens of buckskin and cloth indicate the costumes of 


\section{THE AMERICAN MUSEUM OF NATURAL HISTORY}

these Indians, and their agricultural pursuits are illustrated by samples of corn or maize, beans, squash, etc., remains of which have been found in rock shelters and shell heaps. In hunting and warfare the bow and arrow and war club were the weapons universally employed.

The earliest Indians ${ }^{7}$ who lived in the vicinity of $\mathrm{New}$ York are represented by archæological collections consisting of crude pottery, cooking utensils and other implements made of stone and bone. Some of their pottery is ornamented by incised designs. The stone axe, found in 1850 while excavating for a pond at Thorndale, Dutchess County, New York, is a rare and valuable specimen, while the wooden decoy duck is unique. Models of rock shelters have been constructed to illustrate how the early Indians utilized overhanging ledges as dwelling places. Some of the originals of these rock shelters are still in existence, particularly at Inwood, Armonk and Cold Spring.

In the left-hand wall case will be seen both birchbark and dugout canoes. An unusual specimen in this case is a portion of an original dugout canoe found in New York City in 1906 when making excavations in Oliver Street near Cherry.

In other portions of the hall will be found exhibits from the Penobscot, Delaware, Shawnee, Potawatomi, Ojibway, Menomini, Saulteau, Eastern Cree, Winnebago, Sauk and Fox, Seminole, Cherokee and Yuchi Indians.

The Menomini section is particularly rich in silver work,

${ }^{7}$ The Indians of Manhattan Island and Vicinity-.20. 


\section{THE AMERICAN MUSEUM OF NATURAL HISTORY}

basketry, medicine bags and clothing. The art of these peoples is shown in their porcupine quill and beadwork, basketry and bags. There are charms of various kinds used by witches, and a maple sugar outfit with interesting tradition. It is related by the Menomini that maple syrup formerly ran pure from the trees, but Manabus, their great mythical hero, fearing that mankind would become lazy and worthless if not obliged to work, diluted the syrup with water so that it must now be put through a refining process before it can be used. Of unusual interest are the antique bags woven of basswood string and yarn, most of them bearing designs of the Thunder Bird. In one case will be found a painted robe from a war bundle, the decorations representing all the gods of war, the medicines used in battle, the war leaders and the progressive sections of the war party from the war dance to the scalp dance. This robe is probably the only specimen of its kind in existence. Near-by will be found ordinary smoking and peace pipes of catlinite, and the regalia of the tribal officers of these Indians.

Among the Sauk and Fox specimens are a woman's ceremonial costume, decorated with thirty-nine large discs of German silver, bags woven from material which had been raveled from blankets (some of these are more than one hundred years old and bear designs of humanized forms of birds and other conventionalized bird figures), and decorated rawhide trunks.

The beaded belts and bags of the Winnebago tribe show 


\section{THE AMERICAN MUSEUM OF NATURAL HISTORY}

a variety of ornamental designs. Their medicine bags, buckskin clothing, weapons, household utensils and implements will be found interesting.

The Eastern Cree are represented by birchbark canoes and a tule raft, clothing and charms. In this section will be found fancifully decorated garments made by the Naskapi, an Algonkin tribe related to the Cree.

One of the most important groups is that of the Ojibway. Upon the folk lore of these Indians is based Longfellow's poem "Hiawatha." A large collection of birchbark writings is exhibited in this group as well as examples of beadwork and household utensils.

The Seminole exhibit is one of the three existing collections from these Indians. This tribe formerly occupied the greater part of Florida. In 1832, by treaty with the United States Government, they agreed to remove west of the Mississippi, but the treaty was repudiated by a considerable part of the tribe under the leadership of Osceola, the result being the most costly Indian war in the history of the government. In the end the Indians were conquered and removed to Oklahoma, with the exception of a few hundred who remained in Florida. These took refuge in the Everglades; they still remain hostile to the white man and will seldom permit him to enter their territory. They retain most of their primitive customs, and it is from them that the collection has been secured.

In the south wall cases are collections from the Mackenzie and Plateau culture areas. The Mackenzie Indians 


\section{THE AMERICAN MUSEUM OF NATURAL HISTORY}

are mostly Christianized, and many of them are able to read and write their own language by means of syllabic characters. Their clothing is made from the skin of the caribou and their household utensils are of bark and wood. They travel by birchbark canoes in summer and snowshoes in winter.

In the center of the hall are special cases containing wampum, moccasin and food plant exhibits.

The wampum material illustrates its several related uses by the tribes of North America. In its technical application wampum consisted of cylindrical beads made from shell, some of them white and others dark blue, the latter being the more valuable. Woven in belts or strings it was used to bind a treaty or a contract, and agreements between the tribes were solemnized by the exchange of belts of wampum. White wampum was emblematic of faith and purity. When a nation was summoned to war it received a black wampum belt with the figure of a hatchet in white. In concluding a treaty of peace between the warring tribes, the belts were exchanged as a ratification of the event. In trading between the Indians and the whites, the fathom was the name for the count, and the number of beads varied at different times and places. Under the Massachusetts standard of 1640 , the fathom counted 240 . Connecticut received wampum for taxes in 1637 at four beads to the penny, and wampum was current with silver in the colony in 1704 .

The moccasin exhibit has been selected from a number of type specimens to give an adequate exposition of the 


\title{
THE AMERICAN MUSEUM OF NATURAL HISTORY
}

primitive skin shoe. All varieties of pattern and decoration are represented.

The case of food plants contains samples and lists of the chief cultivated plants in the New World before 1492, most of which have since become world staples. This is the one great contribution of aboriginal New World culture. $A d$ joining is the

\author{
SOUTHWEST PAVILION \\ IndIANS OF THE PLAINS \\ "Lo, the poor Indian! whose untutored mind \\ Sees God in clouds, or hears Him in the wind."
}

Pope.

These collections have been secured from among those tribes of Indians living on the Plains and Prairies west of the Mississippi, ${ }^{\mathrm{s}}$ where formerly ranged the vast herds of buffalo. The flesh of these animals formerly comprised the main article of food of these Indians; the tipi was their home, and the horse with the travois-an A-shaped drag frame of poles - their means of transportation.

The cases are so arranged as to separate those tribes designated as Village Indians from the Nomadic Indians, the latter constituting the majority of the Plains Indians.

In the quadrangle between the entrance from the Woodlands Hall and the exit leading to the Southwest Hall, will be found the specimens obtained from the Village Indians,

${ }^{8}$ North American Indians of the Plains -.25 and .50 . 
while the southern and western portions of the hall contain typical material secured from the Nomadic Indians.

The Village tribes include the Hidatsa, Mandan, SanteeDakota, Osage, Iowa, Pawnee and Wichita, and excellent examples of their handicraft, consisting of decorated parfleches, used for packing clothing, interesting types of basketry, skin vessels, horn spoons, samples of pottery, clothing, decorated buffalo robes and implements used in their games and ceremonials, are displayed.

Representative of the symbolic designs used in their various decorated articles, is a miniature baby board in the Pawnee series. This baby board is symbolic in the sense that it was not made for actual use but was given to a little girl at a ceremony as a part of the prayer for her future well-being. If in the future children should be born to her, a larger board would be made after this pattern. The designs at the head of the board represent the morningstar surrounded by rainbows, the idea being that a child placed on such a board would be under the direct protection of the morningstar, eveningstar and the four gods in the west,lightning, thunder, clouds and wind.

On the top of the right-hand wall case may be seen the primitive round "bull" boats, made by stretching buffalo skins over wooden frames, used by the Hidatsa Indians, and near the center aisle a model of a Hidatsa earth-lodge from the original formerly standing on the Fort Berthold Reservation, North Dakota, which well depicts in miniature the home life of this tribe. 
On the south side of the hall and in the Tower Room adjoining is a comprehensive series of specimens collected among the Plains Cree, Assiniboine, Dakota, Sioux, Crow, Sarsi and Blackfoot Indians.

In the wall case on the left is a valuable lot of specimens collected by the late Colonel Sword. One of the most important objects in this collection is a decorated war shirt of mountain sheep skin. According to tradition, such shirts were formerly worn only by the four head chiefs of the tribe. The fineness of the porcupine quillwork on the costumes and medicine bags and the interesting bead decorations on the leggings and sandals are especially noteworthy.

Displayed in the Assiniboine case are fine examples of porcupine quill and beadwork. These Indians show a preference in their decorative art for dark backgrounds; some show blue or purple, and they have made frequent use of the square (box), cross and feather patterns. In moccasin decoration this tribe used practically every type of design found in the northern plains.

From the Dakota Indians are articles of dress decorated with porcupine quillwork, implements used in their daily life and excellent examples of catlinite pipes of the best known types made by the Dakota; some of the specimens were collected as early as 1840 . The painted robe of buffalo hide, bearing a design known as the Black War Bonnet pattern, is undoubtedly one of the finest robes in existence.

Conspicuous in this collection are the costumes worn by those who participated in the Ghost Dance, a religious 


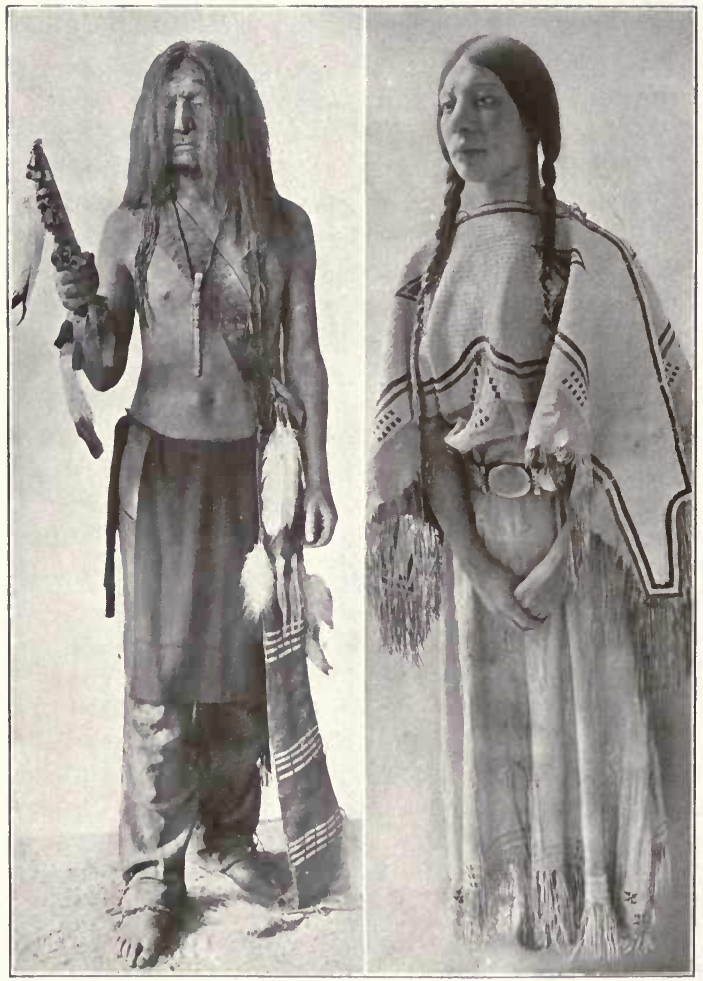


ceremony founded upon the belief in the coming of a Messiah, which resulted in the tragic death, on December 15, 1890 , of Sitting Bull, and which terminated with the massacre of Wounded Knee on December 29 of the same year. These garments, bearing decorative symbolic designs, were worn by all the participants in the Ghost Dance and were believed by them to be bullet proof.

From the Crow Indians are the regalia worn by the members of secret organizations known as the Big Dog Society, Military Society and Tobacco Society, as well as specimens of their clothing and personal accessories handsomely decorated with bead and quillwork.

To those interested in studying the designs employed in decorating material of various kinds, an inspection should be made of the specimens from the Sarsi Indians. Their designs usually consist of a simple geometrical element combined in different colors to make the larger geometrical design which is repeated several times.

The Tower Room is devoted to the collections from the Blackfoot Indians. Models, showing the method of preparing the raw skin of the buffalo and deer, in all its various processes, from the time of the killing of the animal to the finished product, are exhibited, together with specimens of clothing, utensils, implements and weapons used in war and the chase.

The western portion of the hall is given over to the collections secured from the Gros Ventre, Arapaho, Nez Percé, Cheyenne, Comanche, Kiowa, Ute and Shoshone. 


\section{THE AMERICAN MUSEUM OF NATURAL HISTORY}

Here one may see figures in life size of dancers in the various Arapaho Age Societies, gorgeous war bonnets, models of shelters and methods of cooking, peculiar types of baby boards, women's dresses decorated with shells, weapons and many kinds of decorated articles of dress.

The center of the hall contains an unusually interesting Blackfoot Indian tipi, fitted up to show the home life of these Indians. The paintings on the sides of the tipi are those of otters and are supposed to represent a vision of the owner. This tipi was made in 1874 and was used for some time by Heavy Runner, a noted Blackfoot Indian.

In other parts of the hall will be found a genuine medicine pipe from the Blackfoot Indians, and a model of the Sun Dance * of the Arapaho Indians.

* The Sun Dance is a ceremonial which is found among most of the Indian tribes of the Plains. The Arapaho call it Worship Dance or Sacrifice Lodge. It is held annually in early summer, in fulfilment of a vow made during the preceding winter by some member of the tribe who wishes a sick relative to recover. This man, who is accompanied by his wife, is the most important of the dancers. He is placed in the middle of the semicircle of dancers and is painted white. The dance lasts three days and three nights, and during this time the dancers neither eat nor drink. Singing and drumming continue most of the time even at night. The dancers are expected to exert themselves to the utmost to prove their devotion. On the last day they are often overcome by heat and thirst, but they are not allowed to drop out of the dance. The dancing consists in regularly rising on the toes and looking fixedly at the fork of the sacred tree in the center of the lodge. All the dancers are in charge of old men, who are called their "grandfathers." These attend them, instruct them how to act, and sit by them almost continuously. The en- 


\title{
THE AMERICAN MUSEUM OF NATURAL HISTORY
}

\section{WEST WING}

\author{
INDIANS OF THE SOUTHWEST \\ "Once more within the Potter's house alone \\ I stood, surrounded by the Shapes of Clay."
}

The collections from this hall have been secured chiefly from the States of Arizona and New Mexico. ${ }^{9}$ While this area is generally thought of as an arid region, it is well adapted to certain kinds of agriculture. In it are found many prehistoric remains, some of which are undoubtedly the work of tribes still living, while others are further removed. For purposes of study the collections have been divided so as to place those secured from the Nomadic In-

tire dance is under the direction of an old man, who is the keeper of the "flat pipe," the most sacred possession of the tribe, which is believed to have been the first thing that existed in the world. This pipe is wrapped in a large bundle, which is hung on a stand of four sticks set up at the foot of the tree in the center of the lodge. The hoop carried by the man who has pledged the dance is also sacred. Some of the paintings on the bodies of the dancers represent thunder birds, water monsters, dragon flies, trees and lightning. Every dance is held in a new lodge, which is erected very carefully with new ceremonies. At the conclusion of the dance the lodge is abandoned and allowed to fall to pieces. In former times, on the last day of the dance the dancers passed ropes of rawhide through the skin of their breast, and tied them to the sacred tree. They then threw themselves backward until the ropes were torn out of the skin. This self-torture gave the dance the name of "Sacrifice Lodge."

${ }^{9}$ Indians of the Southwest -.25 and .50 . 


\section{THE AMERICAN MUSEUM OF NATURAL HISTORY}

dians-Eastern and Western Apache, Navajo, Pima, $\mathrm{Pa}$ pago and several tribes of Californian Indians-on the right, and those from the Sedentary peoples-those living or who lived in pueblos, caves and cliff dwellings-on the left.

The Eastern Apache, having no fixed habitations, generally lived in buffalo-skin or canvas-covered tipis. Traveling from place to place in search of game, they transported only such material as was not easily broken; thus, the visitor will find but few examples of pottery from these tribes. Such as they did make is noted for its durability, but is lacking in decoration. Their basketry, on the contrary, is well represented. That from the Jicarilla has a foundation of twigs of sumach or willow. They employed vegetable dyes made from the root bark of the mountain mahogany, which gives red, and the root of the barberry, which gives yellow. At the present time they generally use aniline dyes. The Mescalero Apache, on the contrary, choose the leaves of the narrow-leaved yucca plant in different stages of ripeness and dryness and compose artistic schemes without the use of dyes. Both tribes weave geometrical designs in triangles, rectangles and bands, representing certain objects such as mountains, houses, trails, gates, etc. Their basketry water bottles are coated inside with piñon pitch, which renders the vessel water-tight. Besides basketry there are exhibited other specimens illustrating their daily life.

The Western Apache lived in thatched houses; they 


\section{THE AMERICAN MUSEUM OF NATURAL HISTORY}

planted fields of corn each year, making use of irrigation when feasible. Their basketry is similar to that of the Eastern Apache, but it is ornamented in black and white, the white obtained by splitting and shaving willow twigs, the black from the long curved pods of the devil's-claw or unicorn-plant. Samples of beadwork, dress, implements of warfare, food and ceremonial objects are shown.

The Navajo, a large and widely scattered tribe, are well known as the present-day blanket makers of North America. In early times they probably wore garments of buckskin, and they continue to use buckskin moccasins. It is believed that the Navajo did not weave before the coming of the Spanish in 1540. Since the Spanish occupation they have acquired large flocks of sheep, learned how to shear, wash the wool, spin it into yarn and dye it. For a loom a simple frame in which the web is placed vertically is used. The weaving is begun at the bottom, the blanket being lowered as the work progresses. The woof is inserted by the fingers without the aid of a shuttle, continuing only so far across the web as that particular color is needed. The next color is then taken up. Such a blanket has both sides alike in pattern and color, a result difficult to produce by machinery. The woof strands are pressed down with a fork of wood and then firmly beaten down with a batten, the result being a blanket in one piece and quite thick. The collections are replete with wonderful examples of the weaver's art. The Navajo are also adept silversmiths. Many specimens of bracelets, belts, rings and other articles of per- 


\section{THE AMERICAN MUSEUM OF NATURAL HISTORY}

sonal adornment, which have been hammered out from Mexican silver currency, together with the implements used in manufacture, are installed.

The Pima and Papago devote considerable attention to agriculture. They raise corn, beans, melons, etc., utilizing irrigation when necessary. Both these peoples make pottery vessels by applying successive rounds of clay rolled into a long cylinder. After drying in the sun, the vessel is polished and given a coat of red shale or white earth. The firing is done in a small pit. After the first firing the designs are painted with mesquite gum, which becomes black when subjected to a slight refiring. Their basketry is usually of the coiled type. The coiled tray, when turned wrong side up, also serves as a drum on ceremonial occasions or when the medicine man is treating his patients by inagic.

The Yurok, Hupa and Shasta tribes are represented by articles of every-day use, costumes worn in their ceremonials, dances, games, etc.

The currency of the Indians of northern California and the coast north to Alaska consisted of the shells of a small mollusk (Dentalium). Their value was estimated according to their length. The individual pieces were measured by the creases on the fingers, each man having his own determined measure, and entire strings were measured on the arm from the thumbnail to a series of tattooed marks on the forearm. The California Indians were ignorant of the true origin of dentalium, and they have many stories 


\section{THE AMERICAN MUSEUM OF NATURAL HISTORY}

of its being obtained from various animals. Comparison of this primitive currency of the far West, found in this series, with the wampum currency of the extreme East is interesting.

The Maidu of the Sacramento Valley are represented by models of their houses, foods, medicines, clothing and utilitarian objects. Like many of the tribes of California, they make use of acorns for food, and a model illustrating its preparation may be seen.

The Pomo excel in basketry. Soft brown geometrical designs on a background of tan predominate. Certain specimens have small red and black feathers interwoven, while others are entirely covered with yellow and green feathers, with ornamentations of shell. These latter types are rare and very valuable.

The pueblo of Acoma is the oldest continuously inhabited town in the United States. It stands on a mesa 357 feet higher than the surrounding plain, in the western part of New Mexico, and was visited and described by members of Coronado's party in 1540. Acoma pottery is among the best known of any made by primitive peoples and is frequently purchased by tourists. It is highly decorated with conventionalized designs of flowers, clouds and butterflies. A comprehensive series of selected specimens is exhibited, together with the material used in its manufacture.

From the Zuñi have been secured exceedingly interesting articles used in their ceremonials.

The prehistoric peoples of Utah are represented by ex- 
amples of rare and interesting specimens of basketry and pottery.

In the section devoted to the Hopi exhibit is an exhaustive series of images * known as Bahos in the Marau ceremony and Tihus in the Kachina ceremonies.

The Hopi, in the month of August of alternate years, hold a Snake Dance, which is the most widely known of all native Indian dances and is largely attended by visitors from all parts of the world. In this dance live rattlesnakes are used, the priests generally holding them in their mouths. Strange to say, snake bites occurring during these ceremonies have seldom proved fatal.

Another case in this section contains a series of basketry trays used in the women's ceremonies. The dancers appear in the plaza, holding the baskets in their hands and waving them. At the conclusion of the ceremony they are thrown to the spectators, who catch them and preserve them as mementoes. The trays are generally made a short time prior to the dance, and bear designs partly geometrical and partly symbolical, representing beans and other products and various divine persons known as Kachinas.

* These images are not to be considered idols as that word is generally applied, but they do represent supernatural beings, and they are used in ceremonies. After they have been so used, however, they are given to the children to play with as dolls. The more sacred representations of the gods are guarded with jealous care, and are seldom seen except by the initiated members of the priesthood to whom they belong. In this series is a stone image of a mountain lion, an example of such a sacred object. 


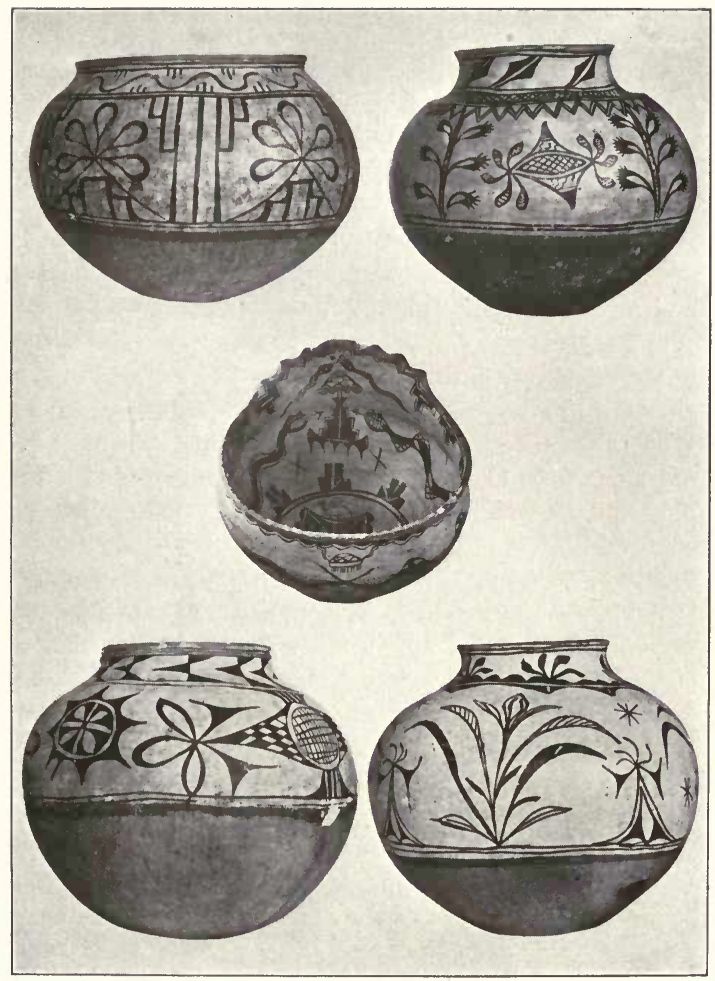

PUEBLO POTTERY 
The last section of this hall contains specimens from the prehistoric pueblos of Bonito and Rio Tulerosa, and the present-day pueblos of Kerensan, San Ildefonso, San Juan and Santa Clara. Of these, Bonito is the largest. It stands close to the wall in Chaco Cañon in western New Mexico; it is 544 feet long and 314 feet wide and consists of about 500 rooms. Numerous examples of the pottery found in this pueblo are exhibited.

In the Tulerosa section is a number of light gray vessels with sharply drawn designs in black. These are probably the finest examples of this type of pottery known. While geometrical designs are the rule, attention is called to a small bowl having a pair of feet drawn on the bottom. The skill in molding is evident from the animal shapes of several of the vessels and the encrusted snake about the border of the bowl. From other sections there are numerous war, hunting and household implements.

From the Taos are specimens of buckskin clothing and other articles of dress, including necklaces of shell, beads and turquoise. One interesting necklace is made of brass beads with eagle claws regularly interspersed. Pipes, both square and tubular, with designs representing lightning and ceremonial objects, are shown.

The south wall case contains a large number of pottery vessels, in many sizes, shapes, colors and designs. The larger vessels are used as storage jars for flour, beans and other supplies, as mixing bowls in the preparation of bread and other foods and as water jars. Many of the pots have 
round bottoms and so need some kind of support to make them stand, while those used as water jars have a depression at the bottom so that they can be easily carried on the head. Carefully composed labels inform the reader how this pottery is manufactured.

In the center of the hall are models of different pueblos, an ancient shrine, a group depicting the daily life of the Navajo and a large case containing ornaments made of turquoise.

In the annex are exceptionally well executed groups illustrating Hopi and Apache home life and a full-sized $\mathrm{Na}$ vajo hogan. 


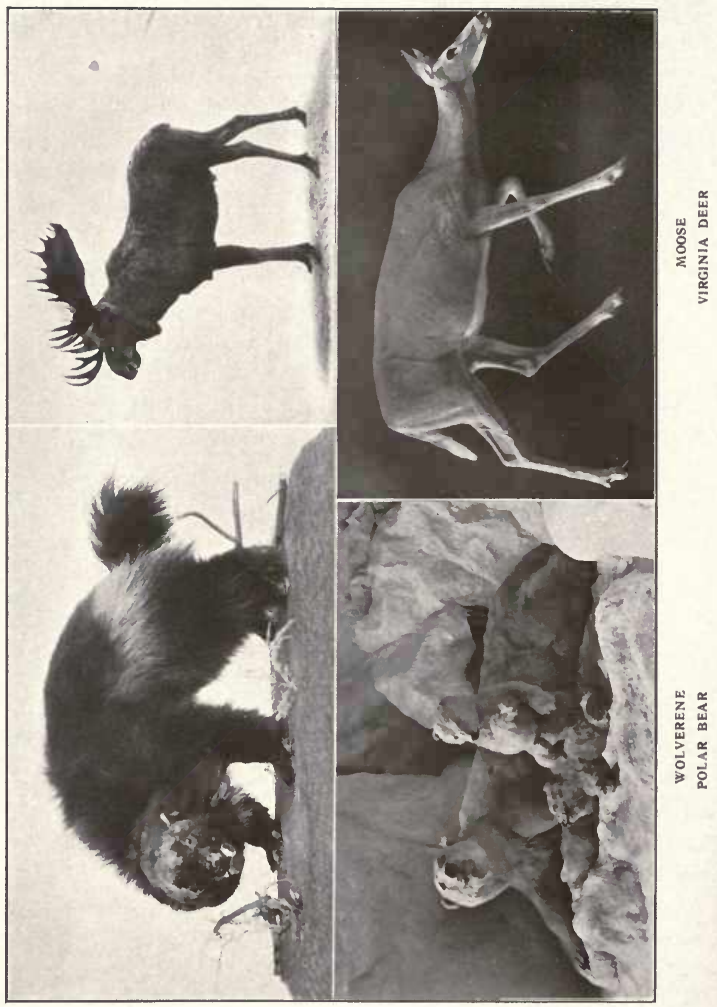




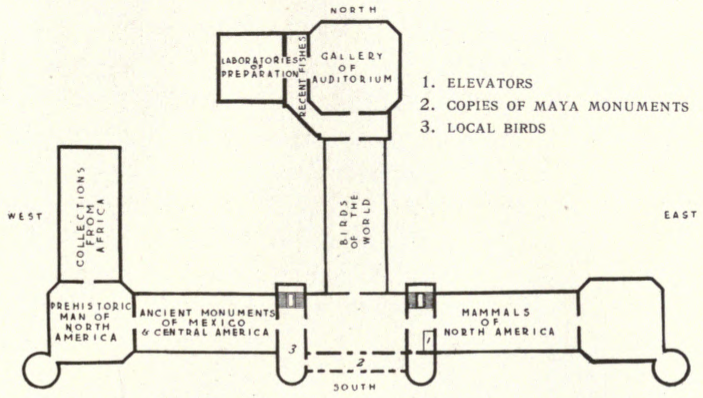

\section{SECOND FLOOR}

\section{SOUTHEAST WING}

\section{Mammals of North America}

As the visitor leaves the elevator on the second floor he faces an admirable painting, "Polaris in Thank God Harbor," by William Bradford. At the immediate left is a portrait of von Humboldt by Julius Schrader. Turning to the right of the elevators, the giant moose of Alaska is the first object to catch the eye. On each side in the west wall cases are groups of small mammals found within fifty miles of New York: opossum, the only common North American representative of the order of marsupials, or 


\section{THE AMERICAN MUSEUM OF NATURAL HISTORY}

pouched mammals, raccoon, red fox, muskrat, mink, skunk, woodchuck, porcupine and gray squirrel. The furs of nearly all these animals are used commercially.

The first large group in the center of the hall is that of the moose, in a setting representing an early autumn scene in a second-growth forest. ${ }^{10}$ This is followed by a group illustrating the color phases of the black bear and by the Lynx and Otter Groups. Adjoining these is a large group of American bison, on a mounting of a typical bit of prairie traversed by buffalo trails, and near-by a group of the Atlantic walrus.

On the south side of the hall are excellent groups of the collared peccary from Mexico, also groups of caribou and musk-ox, which furnish food and clothing to the natives and explorers of the far North, antelope and deer, wild boar from the Black Forest of Germany, polar bear, Stone's mountain sheep from Alaska and bighorn sheep from Montana.

On the north side, the Roosevelt elk or wapiti may be found, followed by groups of Rocky Mountain goat; beaver, showing these industrious little animals busy cutting trees for building dams and houses and the interior of one of their homes; many species of rats, mice, ground squirrels, foxes, bats, coyotes, panthers; an excellent reproduction of a fur seal rookery in the Pribilof Islands, where our government seal fisheries are located; weasels in their summer and winter coats; the ferocious grizzly bear of the

10 North American Ruminants-.10. 


\section{THE AMERICAN MUSEUM OF NATURAL HISTORY}

western United States, and the huge Kadiak bear of the Alaskan Peninsula.

Suspended from the ceiling is a model of a seventy-six foot sulphurbottom whale.

Southeast Pavilion, used as a workroom for the preparation of African elephants and other mammals. Proceed to the

\section{SOUTH PAVILION \\ "Nature is a revelation of God; \\ Art, a revelation of man." \\ Longfellow.}

At the present time this hall contains a varied assemblage of animals, but in the main is devoted to a series of groups of reptiles and amphibians which for composition, detail and exactness are not excelled in any museum.

In the immediate foreground, dominating all others, is a mounted specimen of "Tip," an Asiatic elephant who was the main attraction in Central Park Menagerie for many years. In 1894 it became necessary to kill him because of his treacherous disposition. In the east wall cases are many species of seals. Other conspicuous mammal specimens or groups are those of the sea elephant, the largest of the earless seals and now nearly extinct; an exceptionally well mounted white rhinoceros; Bactrian camel; tigers; Chinese takin, a clumsily built animal with yellowish-brown hair and curiously curved horns, and black rhi- 


\section{THE AMERICAN MUSEUM OF NATURAL HISTORY}

noceros. For want of space many of these specimens are only temporarily arranged.

Quite naturally the visitor's attention will be drawn to the group of king penguins on the north side of the hall. In this case is an actual reproduction of a penguin breeding ground or rookery on South Georgia Island, Antarctica. These grotesque but gorgeously colored birds are shown in various stages of growth. The two central birds, solemnly examining one of their eggs, and one on the right hand, illustrating the method of feeding by regurgitation, are especially attractive.

Arranged in rectangular form in the center of the hall is a series of groups which include the Texas, timber and diamond-backed rattlesnakes, a copperhead den, the Gila monster, iguana, pine snake, deadly moccasin and harmless water snakes. All are mounted in careful detail, each group in surroundings like those in which they are found in life. ${ }^{11}$

Interest centers, however, in the groups on the southwesterly side of the hall illustrating the life habits of certain North American reptiles. ${ }^{12}$ The Museum's artists have here emphasized the character of the work required in the reproduction of groups, intended to represent the natural haunts of the reptiles, by a technique so fine as frequently to cause the observer to wonder which portion is real and which artificial. For the best effect the visitor should stand

${ }^{11}$ The Batrachians of the Vicinity of New York City-.15.

${ }^{12}$ Methods and Results in Herpetology--.05. 


\section{THE AMERICAN MUSEUM OF NATURAL HISTORY}

well back from the groups, when the foreground and background will blend as in a vista in nature.

The giant salamander is most frequently encountered in the streams of western Pennsylvania. In this group the river is represented as flowing toward the observer, in order to show the nests and eggs under the rocks. Salamanders are seen molting, eating crayfish and watching their eggs; there are also young salamanders.

Bullfrogs in the next group are seen in a typical lily pond and in the various stages of life from egg to adult. Certain individuals are casting their skins, swimming, breathing under water and in air, croaking and catching insects, birds and snakes.

Adjoining is a group of lizards as they might be found on a Lower California island. Desert life is pictured in striking contrast to the other groups in this series.

The last group, that of the toad, represents a typical scene in New England in May. Here have been incorporated oak, maple, hornbeam, shadbush and tall blueberry trees and shrubs, and pendent from the new leaves are the glistening water drops from a recent rain. The combination of natural specimens with the work of the taxidermist is so perfect that the question arises in the visitor's mind which is the work of nature and which that of the artisan.

In another part of the hall are specimens illustrating the distinctive habits of some of the animals, for instance, an enlarged model of the bullfrog, showing the peculiar construction of its tongue which enables it to catch insects, the 


\section{THE AMERICAN MUSEUM OF NATURAL HISTORY}

various processes of shedding skin, the "spring peeper" with its vocal sacs inflated, the poisonous bushmaster with its eggs, and the Surinam toad which carries its eggs in the soft tissues of its back where the young are hatched. The perishable parts of many of these animals have been cast in wax from life, thus utilizing in the model only the hard or indestructible parts. This method brings out in detail the principal features, thus doing away with the objectionable and unsatisfactory exhibition of specimens in jars of alcohol.

Suspended from the ceiling is a skeleton of a North Atlantic right whale.

Lack of room has again made necessary the installation, in the lobby adjoining on the south, of casts of certain prehistoric sculptures from Mexico and Central America which ordinarily would be found in the Mexican Hall in the section devoted to the Maya and Nahua cultures. Enter the

\section{SOUTH CENTRAL WING \\ BIRDS OF THE WORLD \\ "I hear from many a little throat, A warble interrupted long." \\ Bryant.}

Beginning on the right, the first four cases contain representatives of the 13,000 known species of birds in the principal groups, arranged according to their natural relation- 


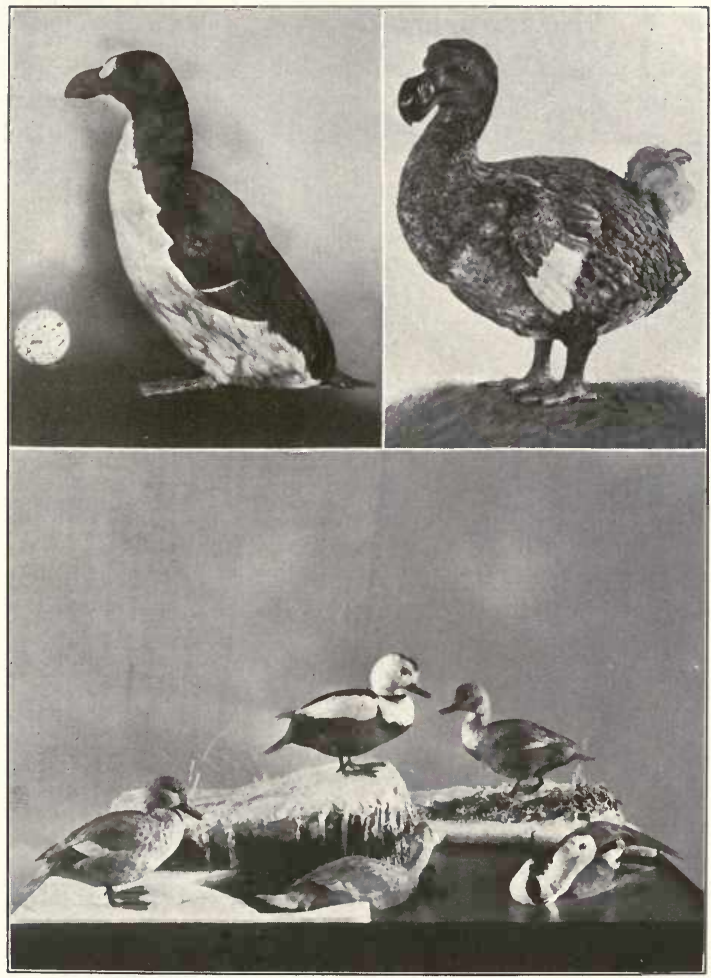

GREAT AUK

DODO

LABRADOR DUCK 


\section{THE AMERICAN MUSEUM OF NATURAL HISTORY}

ships. The series begins with the ostriches, those birds which have changed least from their reptilian ancestors, and terminates with the singing perching birds, such as the thrush and finch, of the highest type of development. The remaining specimens in the cases around the hall are grouped according to their faunal regions, i.e., South American Temperate, American Tropical, North American Temperate, Arctic, Eurasian, Indo-Malay, African and Australian.

Visitors who do not care to inspect every case will be interested in an examination of the hornbill, which has the peculiar habit of sealing the female in her nest when she is "setting"; the varicolored toucans, whose bills are fashioned into spoons by the natives of the different countries these birds inhabit; the Argus pheasant, with its great spreading tail; the gyrfalcon, equipped with its hood and shown as being "pegged out" in the open air; the jungle fowls from Africa, the progenitors of our domesticated chickens; the brilliant colored quetzal with its long plumes, the national bird of Guatemala, and the long-tailed fowls of Japan with tail feathers frequently reaching a length of from twelve to fourteen feet.

In the center of the hall are cases containing groups of extinct or nearly extinct birds:

The Heath Hen, common in the early part of the last century in portions of Massachusetts, Long Island and New Jersey. The near extinction of these birds is due to excessive shooting at all seasons; when the present specimens 
were secured in 1907 from Martha's Vineyard, not more than one hundred individuals were known to exist. This bird has the general habits of the prairie hen, but frequents a bushy rather than an open prairie country.

The Dodo, of which a restoration and skeleton may be seen. The Dodo was a strange kind of pigeon about twice the size of a turkey and was found on the Island of Mauritius by the Portuguese about 1507. The last authentic record shows that there were individuals alive in 1681 .

The Great Auk, of which no living specimen has been recorded since 1844. This bird formerly bred on a few small islands off the coast of Newfoundland and during its migration was known along our coast as far south as Virginia. Being flightless and helpless on land, it proved an easy victim for the early voyagers and fishermen, who killed the birds in vast numbers for their flesh and feathers.

The Labrador Duck, which formerly was somewhat common on the Atlantic coast from Labrador to Chesapeake Bay. No living specimen of this bird has been recorded since 1871 , although as late as 1850 it was met with occasionally in New York markets. Only forty-odd specimens are known to be preserved in museums. Of these, thirtyone are in America, seven of which are in this institution. A perfect skin of this bird now has a value of more than $\$ 3,000$.

The Wild Pigeon, which in 1805 was so numerous that Audubon wrote that he saw schooners at the wharves in New York City loaded in bulk with wild pigeons caught up 


\section{THE AMERICAN MUSEUM OF NATURAL HISTORY}

the Hudson River, which were sold at the rate of one cent each. The last individual died in the Cincinnati Zoölogical Gardens in 1914.

Near-by is a group indicating the relation between structure and habit in birds as illustrated by woodpeckers, followed by a case containing specimens of nearly all the known varieties of the birds of paradise.

In alcoves will be found small groups of various birds and series of birds' nests and eggs, showing the size of the egg and the number in the clutch. Of special interest in the case containing the ostriches, is an egg of the Æpyornis, one of the several species of gigantic extinct birds distantly related to the ostrich and known only from bones and eggs found in the forests of southern Madagascar. This egg has a capacity of six times that of the ostrich egg, 140 fair-sized eggs of the common hen or 18,000 eggs of hummingbirds. They were frequently used for bowls and water jars. Stories of their size, told by Arabian traders, gave rise to the fable of the roc, a giant bird which could carry off an elephant. It is said that when the present natives of the island find one of these eggs, they hold a feast in honor of the event, at which time they sacrifice several oxen.

From the ceiling hangs a skeleton of a finback whale sixty-two feet in length.

At the rear of the group of birds of paradise has been temporarily installed a portion of the collection of recent fishes. 


\section{CENTRAL PAVILION}

\section{Recent Fishes}

This exhibit is composed of typical examples of the various groups of vertebrates popularly comprised in the term "fishes." The collection is arranged by groups in the following order:

1. Lampreys and Hagfishes. These are eel-like creatures with round sucking mouths and no jaws-in this unlike fishes in the true application of the word. They are without scales, true teeth or paired limbs, and their backbone is but a thread of cartilage.

2. Sharks and Rays, which are fishes with soft skeletons and small bony scales. They are the most primitive of the ancient type of fishes. Numerous specimens will be found suspended from the ceiling and in cases.

3. Chimæroids or Ratfishes. These are nearly scaleless, living mostly in the deep sea and belonging to the group of silver sharks. The most characteristic forms are represented by models.

4. Lungfishes, found in the rivers of Australia, Africa and South America. These ancient and nearly extinct forms of salamander-like fishes are shown by specimens of the three surviving types. The African type passes the months when the streams are dried up in cocoon-like form, during which time it breathes only with its lungs. 


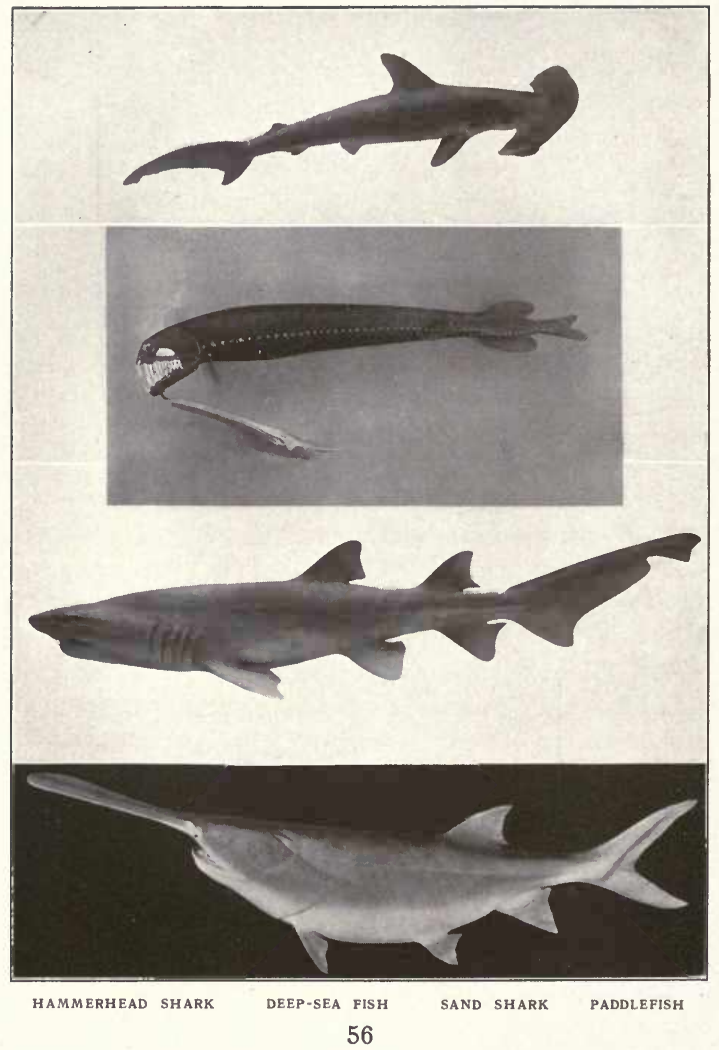




\section{THE AMERICAN MUSEUM OF NATURAL HISTORY}

5. Ganoids, which are mainly bony-scaled fishes and were most numerous in the early geologic ages. The sturgeon, garpike, paddlefish, bowfin and African bichir are among the present survivors. An excellent habitat group of the paddlefish is reproduced. The roe of these fishes is an important article of commerce and constitutes what is known as "American caviar."

6 . Teleosts or Bony Fishes. This group comprises about 10,500 species, or more than nine tenths of all the forms of our food and game fishes. A selected number of examples of this group is temporarily installed in the Bird Hall and includes bass, carp, cod, eel, herring and tilefish, which latter recently has become a popular food fish.

Inspection should be made of the Deep Sea Group, showing types found at a depth as great as 3,000 fathoms, or more than three miles. Nearly all the deep-sea fishes are provided with luminous organs which are distinctly brought out in the group by a cleverly arranged electrical device. Near-by is the mounted record specimen of an ocean sunfish (Mola), measuring ten feet two inches from tip to tip. In other parts of the Corridor are groups of the shovel-nosed sturgeon, bowfin and garpike. 


\title{
THE AMERICAN MUSEUM OF NATURAL HISTORY
}

\section{WEST CORRIDOR}

\author{
LOCAL BIRDS \\ "Never look for birds of this year in \\ the nest of last year."
}

Cervantes.

In this room are specimens of all the varieties of birds which have been known to occur within fifty miles of New York City, a General Collection of all birds likely to be seen within this area, arranged according to the American system of classification, and the Seasonal Collection which is changed each month so that those interested in the study of bird life may ascertain what birds they may expect to find during the current month.

In another section are the stragglers from other parts of the country which have been found within our limits. Then, too, there is a table case containing the eggs, often with the nest, of those species known to nest within fifty miles of the city, and facing the entire collection a well executed life-size bust of John Burroughs, that ardent lover and keen and kindly observer of nature.

At the extreme northern end of the Corridor along the stairway is a number of original plates, drawings and paintings by John J. Audubon. 


\section{SOUTHWEST WING}

Ancient Monuments of Mexico and Central America

"At every step some palace meets the eye,

Some figure frowns; some temple courts the sky."

Southey.

Here is contained an exposition of the most ancient monuments of Mexico and Central America. The reproductions are chiefly from sculptures of Maya and Nahua Indians made before Columbus reached America. ${ }^{13}$

On the left is an exhaustive series of pottery, jade and stone work, mostly from Costa Rica, deposited in the $\mathrm{Mu}$ seum by Minor C. Keith. This collection is supplemented by more than 500 gold specimens which have been placed in cases in the center of the hall. All of them are of preSpanish times and were made when many ornaments were worn by the Indians. They include beads, pins, nose and arm trinkets and a large number of golden bells in the form of monkeys, jaguars, birds, butterflies, frogs and lizards. Singularly, vegetative motives are almost entirely lacking. Accompanying the gold objects are ornaments of polished jade, the designs upon which are highly conventionalized figures of birds and animals; also of interest are a few original molds made of rosin, which when used in the process of manufacture were encased in clay, the pitch ${ }^{13}$ Hand book in press. 


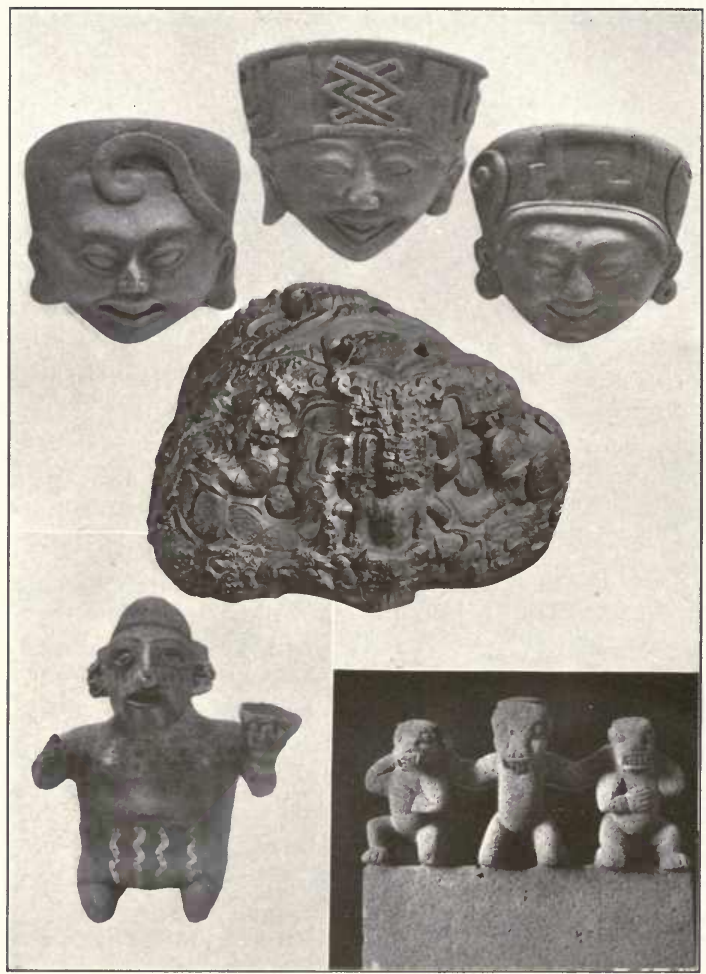

MEXICAN AND CENTRAL AMERICAN SCULPTURES 


\section{THE AMERICAN MUSEUM OF NATURAL HISTORY}

being melted out and the gold poured in. Mixed casting, as well as plating, is represented.

Opposite the Costa Rican material is a number of stone sculptures made by the Maya peoples, who were remarkable above all other cultured American nations for their architecture, calendar and hieroglyphic system. Their hieroglyphic records were carved or painted originally upon the walls of their temples and palaces, or written in books made of maguey paper. A great deal of attention has been given to the Maya language, which has been forceful enough to remain unsupplanted. Many of the monuments bear designs of priest-like beings who carry serpents and other ceremonial objects in their hands.

There is a number of reproductions of the stelæ and altars of Copan arranged in order from the oldest and crudest forms to the latest and finest examples, covering a period of nearly three hundred years. The early stelæ are characterized by carvings in very low relief with sharp corners, while the later monuments are cut deeper and in more rounded form. In the collection is the cast of the so-called Turtle Stone of Quirigua, which represents a twoheaded monster covered with several layers of ornaments. A small model standing in front of the large cast will permit the visitor to make a close examination of the designs.

Nahua culture is represented by many pottery, copper, obsidian and jade objects and by musical instruments. In one case are facsimile reproductions of native books or codices, originally painted in freehand on strips of deer 


\section{THE AMERICAN MUSEUM OF NATURAL HISTORY}

skin. The early Spaniards, in their zeal to destroy the - native religion, burned hundreds of these books, which recorded their ceremonial rites and historical events. Occasionally, for preservation, some of these were pasted on the walls of the native churches and coated with light plaster, in later years to be brought to light by explorers.

The Aztecs, the principal tribe to settle in Mexico, founded their capital city, called Tenochtitlan, on marshy islets in Lake Texcoco about the year 1325. Tradition states that this location was pointed out by the gods. An eagle perched upon a prickly pear cactus plant, the nopal, strangling a serpent, now forms the national seal of Mexico.

The cast of the sacrificial stone, or Stone of Tizoc, at the west end of the hall, is a record of some of the principal Aztec conquests made before 1487, and the calendar stone on the south wall is a graphic representation of the four prehistoric creations and destructions of the world, as well as a symbol of the sun and a record of the divisions of the year.

In another portion of the hall is a model of a cruciform tomb found at Guiaroo, near the ruins of Mitla. A large reproduction of this tomb, in part, may be found by visiting the restaurant in the basement of the building. 


\section{SOUTHWEST PAVILION}

\section{Prehistoric Men of North America}

This hall, in the main, is given over to a systematic outline of the archæology of North America; the exhibit in the Tower Room adjoining, to Old World archæology. The objects have been grouped according to areas and states. Typical objects of ancient pottery, arrow-heads, stone axes and other implements of stone and bone, most of which are from burial mounds, are exhibited. The most important of these are the rude implements and fragments of human bones from the Trenton gravels, which form conclusive evidence of the antiquity of man on this continent. The cases on either side of the entrance to the Tower Room are devoted to physical anthropology.

In the Tower Room, adjoining, will be found many stone implements and rude carvings from men of the Old Stone Age of Egypt, Denmark and southwestern Europe. Upon the walls are copies of paintings of bison, mammoths, horses, wolves and reindeer from the caves of Altamira and Font de Gaume in Spain and France respectively. It is of interest to compare the crude stone implements of this period with those finely worked objects of a similar nature in the collections of our early Indians in the hall just visited. 


\title{
WEST WING
}

\author{
Collections from Africa \\ "So geographers in Afric maps \\ With savage pictures fill their gaps."
}

Swift.

This hall differs from others containing ethnographical specimens in having introduced a number of characteristic African mammals. While inspecting the exhibits the visitor would do well to bear in mind that the installation is geographical, i.e., collections from the natives of south Africa (Bushmen, Hottentots and Negroes) are installed on the south or entrance side of the hall, those from the tribes of east Africa on the right or east side, those from the north at the north end, and those from the west along the west side.

On the south the exhibits are given over to material collected from among the Bushmen, the most ancient and primitive of African natives. Full-size, life-like plaster figures of the natives, also their works of art and their implements, are exhibited. That the negro is above all an artisan in iron work is demonstrated by the finished products (curiously formed knives, axes and spears) which are in evidence throughout the hall. While his work as a blacksmith seems to predominate, one must not lose sight of his work in textiles. In the large central rectangle devoted to Congo ethnology, are beautiful examples of this 


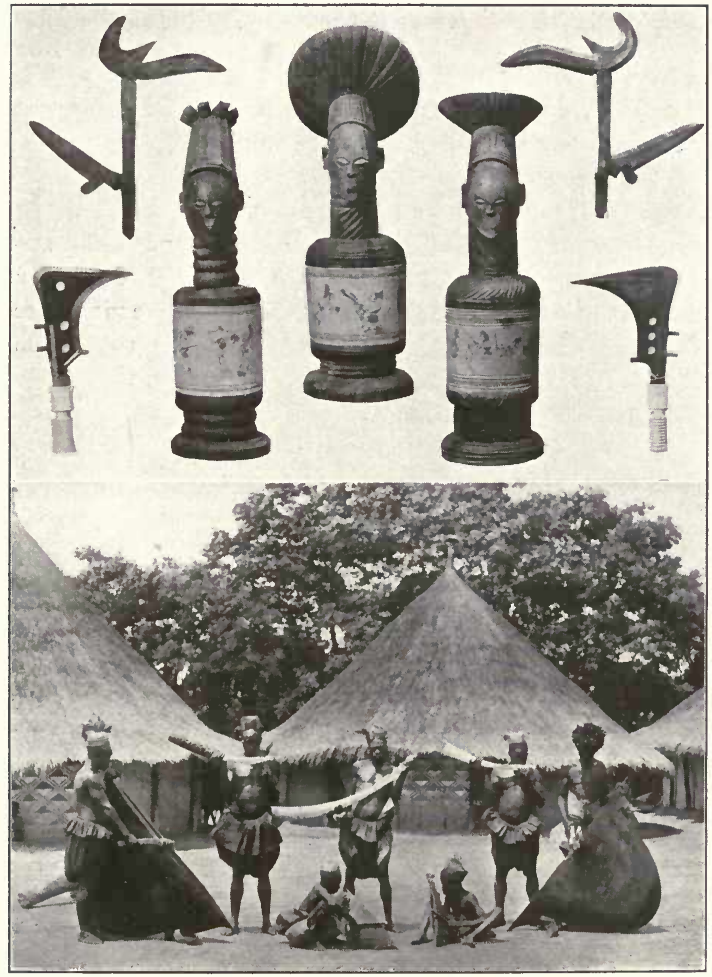

AFRICAN KNIVES AND BOXES

AFRICAN VILLAGE

NATIVES WITII SPECIMENS SECURED BY LANG-CHAPIN EXPEDITION 


\section{THE AMERICAN MUSEUM OF NATURAL HISTORY}

art. The products of the loom are represented by the beautifully woven pile cloths of the Bakuba, woven by the men from patterns supplied by the women.

In addition are numerous finely carved wooden vessels, images, basketry and well molded pottery vessels. In the northwestern section of the hall are bronze and brass castings made by a process similar to that used in Europe in the Renaissance period. Throughout the collections are numerous fetiches and charms believed to give security in battle or to avert sickness or evils. Masks used by medicine men are also in evidence.

As an addition to the general attractiveness of the arrangement of the specimens, there is a mural border of typical scenery of the several sections of the Dark Continent.

When space is available these collections will be greatly enhanced by the addition of material secured on a Museum expedition maintained in Africa from 1909 to 1915. 


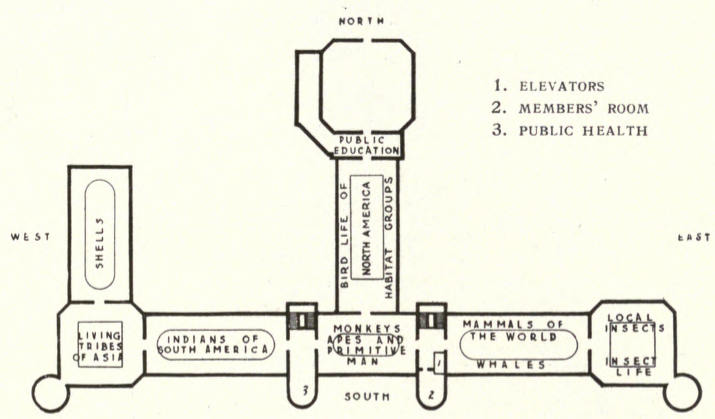

\section{THIRD FLOOR}

\section{EAST CORRIDOR}

To the left of the elevators is a room for the use of the Members of the Museum. Near-by is a bronze tablet in memory of Jonathan Thorne, through whose generous bequest it is possible for the Museum to provide lectures and objects for the instruction of the blind.

On the stairway walls are caribou skulls and antlers. 


\title{
SOUTHWEST WING
}

\author{
MAMMALS OF THE WORLD
}

At the entrance of this hall is a well mounted specimen of "Hannibal," an African lion.

The exhibit is designed primarily as an introduction to the study of the orders and families of Mammals* and to indicate the relationships of existing mammals to one another and their point of origin in the past. The series includes a typical or characteristic example of every family of existing mammals. A line is drawn from each specimen

* The class Mammalia is divided into three subclasses: Prototheria, Metatheria and Eutheria.

The first contains a single order, Monotremata, represented by the duck-billed Platypus and Echidna (spiny anteater) of Australia.

The second likewise contains a single order, Marsupialia, or pouched animals, like opossums, kangaroos, wombats, etc.

The third subclass is the largest and most important and embraces Insectivora, the insect eaters, like porcupines, shrews and moles; Chiroptera, the bats; Carnivora, flesh-eating mammals, like bears, ocelots, wolves, coyotes, martens, hyenas, walruses, seals, etc.; Rodentia, the gnawers, including squirrels, rabbits, mice, rats, beavers, etc.; Edentata, such as sloths, lesser anteaters and armadillos; Ungulata, a very important group of hoofed animals, containing deer, tapirs, rhinoceroses, horses, swine, camels, cattle, giraffes, goats, sheep and a few others; Proboscidea, elephants, extinct mammoth, mastodon, etc.; Sirenia, dugongs and manatees; Cetacea, whales and dolphins; Primates, the highest order, comprising lemurs, monkeys, apes and man. 


\section{THE AMERICAN MUSEUM OF NATURAL HISTORY}

to a diagrammatic representation of the later geologic periods-Tertiary and Quaternary - indicating the time in the world's history at which the given family probably originated. The visitor should examine first the wall case on the left containing specimens illustrating the Characters and Evolutionary Rank of Mammals and follow the series around the room. It has been so arranged as to present in graphic form the past history and development of the principal divisions.

In another part of the hall is a life-size model of a sulphurbottom whale seventy-six feet in length. Attached to one of the pillars may be seen a model of a whale's head showing the whalebone, which takes the place of teeth and hangs in great plates from the inside of the upper jaw. Suspended from the ceiling are models of other whalebone whales and of the toothed sperm whale, and skeletons of smaller whales.

Circling the hall is a marine mural frieze which serves as a background for models of porpoises, dolphins and other members of the whale family.

In the railing cases are exhibits which give the visitor a general view of the enormous Class of Insects. There is a special exhibit of the Butterflies ${ }^{14}$ Found Near New York City, another of the "Moths of the Limberlost" and one of the Plant Galls Caused by Insects.

${ }^{14}$ Our Common Butterflies-.15. 


\title{
SOUTHEAST PAVILION
}

\author{
HaLl of INSECt LifE \\ "For where's the state beneath the firmament \\ That doth excel the bee for government?"
}

Du Bartas.

The installations in this hall are arranged in a continuous series, beginning at the rail cases farthest to the left, and are numbered so that they can be easily followed.

First is the section showing the importance of insects, i.e., the losses they occasion to crops and the diseases spread by them, also the benefits they render by pollination of many of our crops and flowers.

Next are sections explaining the terms used in the classification of insects, ${ }^{*}$ followed by a series giving a summary of the principles of evolution, as illustrated by insects.

* Insects are grouped into orders mainly according to the nature of their wings. Beginning with the highest class of Insecta and passing downward, the principal ones are as follows:

Diptera-Flies, mosquitoes, gnats, midges and others: Twowinged insects with mouth parts formed for sucking.

Hymenoptera-Bees, wasps, ants, ichneumon flies and other insects having four membranous wings with few cross veins. Mouth parts formed for biting and sucking.

Coleoptera-Beetles. Insects with hard wing covers, the inner membranous pair used for flying. This is the most numerous order. 


\section{THE AMERICAN MUSEUM OF NATURAL HISTORY}

Following is a series of exhibits concerned with the life histories of insects, their relation to vegetation, their enemies and the means used by man to combat the injurious species.

In other sections of the hall are exhibits of silkworms, honey bees, seventeen-year cicada, mound-building ants, a group of monarch butterflies as they are found during their migratory period in early autumn, and a revolving case showing the iridescence of opaque insects.

The general study collection ${ }^{15}$ is not on exhibition but may be seen on the Fifth Floor by visitors desiring to make a more extended study of insect life.

Lepidoptera-Butterflies and moths. Insects with four wings, covered with overlapping scales. Mouth parts for sucking.

Hemiptera-All true bugs, plant lice, seventeen-year locusts. Insects having four wings. Mouth parts formed for sucking.

Neuroptera-Ant lion, dobson and others. Insects having four membranous wings with numerous veins. Mouth parts formed for biting.

Odonata-Dragon-flies and others. Insects with four membranous wings finely netted with veins. Mouth parts for biting.

Orthoptera-Grasshoppers, katydids, crickets, walking sticks and others. Insects usually with four wings, the outer pair being straight and not used actively for flying, the inner pair or flying wings folded like the plaits of a fan. Mouth parts formed for biting.

Thysanura-Spring tails, bristle tails and others. Insects without wings, which undergo no metamorphosis. In some cases there are, in addition to the six legs belonging to all insects, rudimentary legs on the abdomen. The Thysanura form a kind of connecting link between the other insects and the myriapods.

${ }^{15}$ How to Collect and Preserve Insects-.10. 


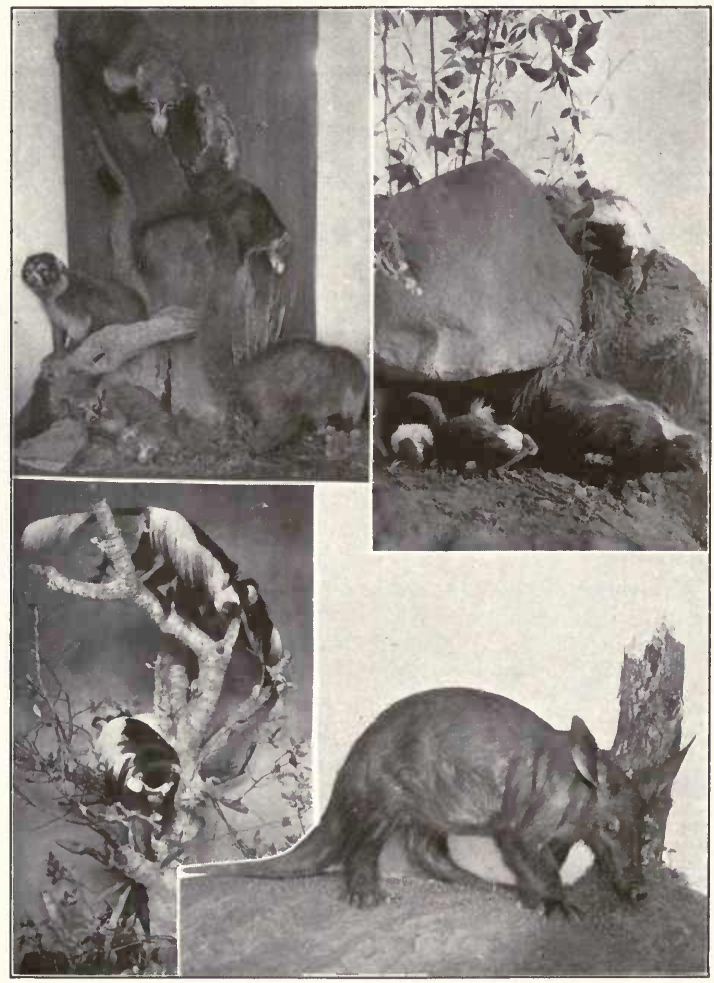

MEXICAN COATI

COLOBUS MONKEY
SKUNK

AARD-VARK 


\section{SOUTH PAVILION}

\section{Monkeys, Apes, Rodents and Bats}

This hall is in course of rearrangement; in the final plan $i t$ is intended to include primitive man as well as the other members of the order Primates.

Facing the entrance is a group of Colobus monkeys. The specimens in the group have been selected to show the stages of coloration from youth to old age. The young are born white, but their color changes so rapidly that this fact was long doubted even by scientists.

On three sides of the hall-north, east and south-are representative specimens of monkeys of the Old and the New World. One large case contains a family of orangutans, one of the first groups of large animals to be mounted in this country, and adjacent are examples of the gorilla. The chimpanzee, "Mr. Crowley," who died in 1888, after living in Central Park Menagerie for five years, is near-by. In another case is a group of bats, the only mammals that fly, and in a wall case on the west are lifesize figures of the three best defined races of man, i.e., the White or Caucasian, represented by a figure of a Norwegian woman in holiday attire, the Yellow or Mongolian, by that of a Chinese farm laborer, and the Black or African race, by "Manziga," a native African chief of the Azande tribe.

In other portions of the hall are groups of birds: wood- 


\title{
THE AMERICAN MUSEUM OF NATURAL HISTORY
}

cock, grouse, quail, partridge, white-crowned pigeon and water ousel. The last named bird has the peculiar habit of suddenly diving into the water and while beneath the surface walking quietly about feeding among the pebbles on the bottom.

From the ceiling hangs a skeleton of the North Atlantic right whale. Proceed to the

\section{SOUTH CENTRAL WING}

\author{
Habitat Bird Groups \\ "Happy birds, that change their sky \\ To build and brood; that live their life \\ From land to land."
}

Tennyson.

Preëminent for their faithful portrayal of the life of birds are the groups which the visitor should now inspect. Designed to illustrate not only the habits but also the haunts of the species represented, there are usually installed in each group adult bird or birds, nest, eggs and young. The pictures of their homes are from nature, not fanciful sketches, each with its definite locality, therefore possessing a geographical as well as an ornithological value. ${ }^{16}$

Beginning with the case at the entrance and passing to the right, the groups are arranged in the following sequence:

Orizaba Group. In the foreground is the luxuriant vege16 The Habitat Groups of North American Birds-.25. 


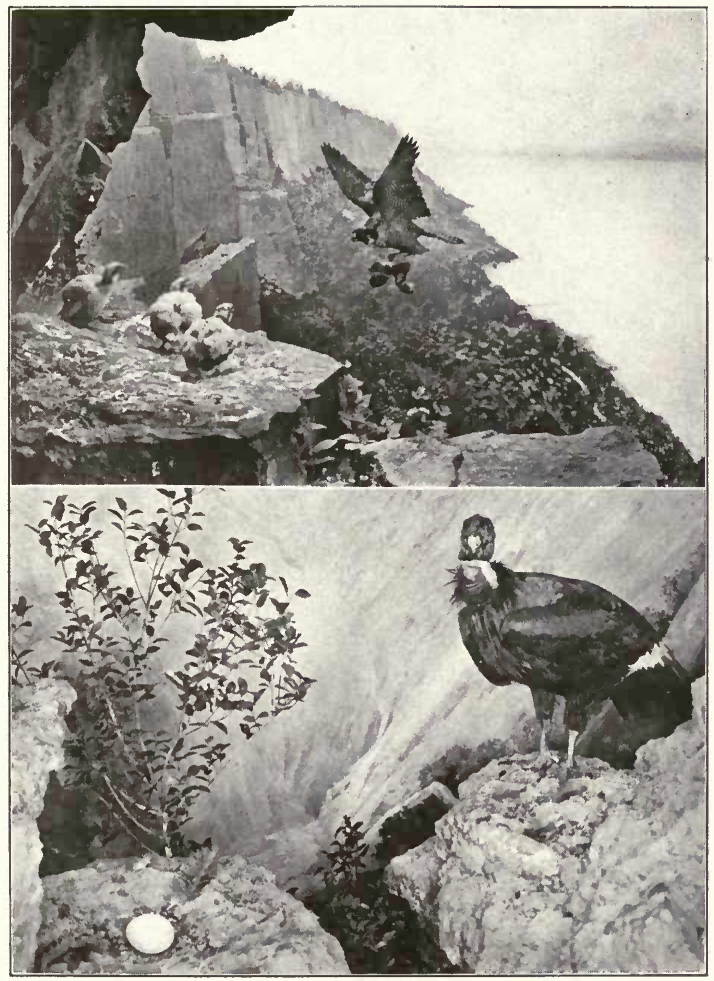

DUCK HAWK

CALIFORNIA CONDOR

75 


\section{THE AMERICAN MUSEUM OF NATURAL HISTORY}

tation one finds at the upper border of the tropical zone. Perched in this growth are parrots, toucans, trogons, motmots and other tropical birds. The studies for this view were made at Cordova, Vera Cruz. In the central background is snow-capped Orizaba, on the left a view of the Rio Blanca.

Summer Bird Life of Cobb's Island. Common terns, skimmers, gull-billed terns, oyster-catchers, Wilson's plovers and other birds are shown on a portion of a shellstrewn sand-bar, Cobb's Island, off the coast of eastern Virginia. This locality forms an ideal resort for sea-birds, beyond the reach of their most common enemies, and the surrounding waters furnish an abundant and unfailing food supply.

Duck Hawk. Fearless in pursuit of its prey. An adult bird is bringing a pigeon to its young. The nest is shown against a background representing the Palisades of the Hudson northward from "The Gorge" at Englewood, New Jersey. Across the river on the right is Yonkers.

August Bird Life of the Hackensack Meadows. Travelers to and from New York are familiar with the marshy land about the Hackensack River and Newark Bay, but few realize the abundant bird life found in the rushes at this season of the year. Specimens of bobolink, sora, redwinged blackbirds, swallows, rails and the rare wood duck may be seen in the group among the rose mallows, cardinal flowers, sagittaria and pickerel weed. 
Wild Turkey. Distinctly an American bird which formerly ranged throughout the wooded portions of the eastern United States from southern Maine and southwestern Ontario, southward to Florida, New Mexico, Arizona and the Mexican tablelands. The wild turkey has now become rare and is seldom found farther north than Pennsylvania and Ohio. The birds differ from the domesticated turkey chiefly in the color of the tips of the tail feathers and upper tail-coverts.

Florida Great Blue Heron. While a rather homely object on the ground, in flight, with its neck folded and great wings slowly flapping, the heron appears quite stately. Herons are often miscalled "cranes." They are found throughout North America, and live on frogs, fish and reptiles.

Water Turkey or Snakebird. A few miles west of St. Lucie, Florida, may be found a scene such as is here depicted. The water turkey has also been called "snakebird," from its resemblance to a serpent when swimming near the surface, with its long, slender, snakelike neck above the water. The young of these birds, like the young of pelicans and cormorants, secure their food from the parent's throat.

Sandhill Crane. These birds are still to be found on the great Kissimmee Prairie in Florida. In March they commonly build a little island nest in the water-filled depressions with a species of pickerel weed. Their nest-building 


\section{THE AMERICAN MUSEUM OF NATURAL HISTORY}

is preceded by singular antics of courtship-males and females hop, skip and jump about, bowing low and leaping high, all the time croaking and calling.

Brown Pelican. The studies for this group were made on Pelican Island in the Indian River of Florida. The birds are shown in different stages of growth and in various occupations. In the foreground may be seen several young birds feeding on the predigested fish which has been regurgitated by the parent bird.

American Egret. Probably no species of bird has suffered more from the depredation of the plume hunter than the egrets. Now that adequate laws have been framed and provisions made for their preservation, these birds may again become as numerous as in former years. The aigrettes are acquired by the birds prior to the nesting season. As the season advances they become frayed and dirty and are shed. The sketches for the background were made from trees at an average height of forty-five feet. The birds were studied and photographed from a mossdraped blind attached to the limb of a tree in a rookery in the swamps of North Carolina.

Turkey Vulture or Turkey Buzzard. Once regarded as a useful scavenger and protected by law, it is now regarded with suspicion on account of its spreading hog cholera as a result of feeding on carrion. The locality shown is Plummer's Island, in the Potomac, just above Washington.

Cactus Desert Bird Life. Mockingbirds and thrashers, 
cactus wrens, road-runners, quail, nighthawks, doves, sparrows and other birds are shown on a great cactus-covered desert, characteristic of the more arid portions of southern Arizona. Various species of cactus, candle bush and palo verde in blossom form part of the accessories.

California Condor. The studies for this group were made in Piru Cañon, fifty miles southwest of Santa Barbara, California. The condor's rapid decrease is believed to have been caused by its feeding on poisoned carcasses of sheep and other cattle exposed by ranchmen as a bait for predatory animals.

Brandt's Cormorant. About a quarter of a mile off the coast near Cypress Point, Monterey, California, is such a scene as is here pictured. The cormorant is an expert diver and the Chinese and Japanese fishermen make use of it as an assistant in their occupation.

Summer Bird Life of the San Joaquin Valley. Formerly a dry and arid region, irrigation has transformed this land into a series of creeks, ponds and marshes. In the group are stilts, avocets, killdeer, terns, night herons, ibises, coots, and various species of ducks. The studies for this group were made at Los Baños.

A Flamingo Colony. Prior to 1904 , the time when the studies for this group were made, very little was known concerning the nesting habits of flamingoes. At this time an expedition from the Museum to the Bahamas was successful in discovering a rookery containing more than 2,000 


\section{THE AMERICAN MUSEUM OF NATURAL HISTORY}

birds and in making a series of studies and photographs of their habits. The birds lay a single egg in May in a nest constructed by scooping up mud with the bill and patting it down with the bill and feet. The nests are raised to a height of from eight to fourteen inches to protect the contents from water. Both sexes incubate, one by day and the other by night. The young bird is fed by the mother on predigested food. When hatched it is covered with brown colored down, and it does not assume the brilliant plumage of the adult until five or six months old.

The Booby and the Man-o'-War Bird. The male mano'-war bird has a remarkable habit of inflating its throatpouch until it resembles a toy balloon. With its great wing expanse of between seven and eight feet, the man-o'-war bird is one of the most powerful and graceful of fliers. The boobies were found to nest only on the ground. The scene is reproduced from studies made on Cay Verde, a coral islet in the Bahamas.

A Florida Rookery. In the group are roseate spoonbills, snowy American egrets, herons, ibises, cormorants and water turkeys. Studies made on an islet in Cuthbert Lake, Florida.

Whistling Swan. These birds are noted for their clear, far-reaching voices. They are fierce fighters, striking dangerous blows with the bony knob on the wing and using bill and claws vigorously. This is now one of the rarest birds in North America, there being no recent records of its nest- 


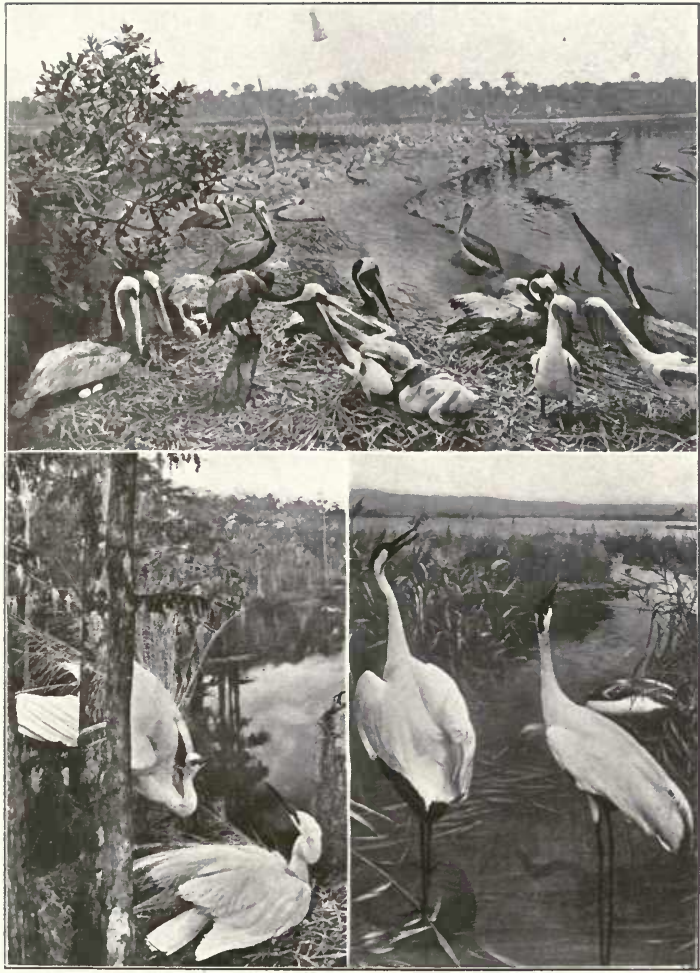

BROXN PELICAN

EGRET

WHOOPING CRANE 


\section{THE AMERICAN MUSEUM OF NATURAL HISTORY}

ing. Reproduced from studies made on Southampton Island in the mouth of Hudson Bay.

Whooping Crane. This is the largest bird in the United States, measuring four feet from tip of bill to tip of tail, from seven to eight feet from tip to tip of the wings and standing nearly as tall as a man. The group shows the birds as they doubtless once appeared on the shores of Heron Lake, Minnesota, a region they are known to have inhabited.

Golden Eagle. The natural food of the golden eagle in the west consists chiefly of small mammals, such as prairie dogs, rabbits and squirrels, but also of ducks and grouse. Occasionally it takes a young deer or antelope. On the whole, however, it is a beneficial bird because of the large number of rodents it destroys. Where sheep have been introduced it may become more or less injurious through its acquired habit of preying on lambs. It differs from the bald eagle, the common eagle of the eastern states, in color and in having the legs feathered quite to the toes. Reproduced from studies made at Bates's Hole, fifty miles north of Medicine Bow, Wyoming.

A Klamath Lake Bird Colony. On the borders of Klamath Lake, situated in northeastern California on the Oregon boundary line, a number of colonies of white pelicans, California and ring-billed gulls, terns, cormorants and blue herons have established their nests. The group shows the border of a tule island in the Lake, while in the background 


\section{THE AMERICAN MUSEUM OF NATURAL HISTORY}

are other bird-inhabited islets, the surrounding treeless hills and Mount Shasta in the distance.

Arctic Alpine Bird Life. Eight thousand feet above the sea, where the summits of the Rocky Mountains, Sierras and Cascade Range reach above timber-line to the regions of perpetual snow, there is bird life such as appears in this group: white-tailed ptarmigans, snow finches and pipits. Great white anemones, heather and other flowers are in bloom. The studies for this group were made in the Canadian Rockies about fifteen miles north of Laggan at the Ptarmigan Lakes. Mount Temple, Mount Redoubt and other peaks of the range are easily identified.

Sage Grouse. This well known game bird is found in the high sage brush on the Plains, from western Nebraska and western Dakota north to the Canadian boundary, west to eastern Oregon and northeastern California, east to the Sierras and south through Utah and Nevada. The studies for the group were made at Medicine Bow, Wyoming, on the line of the Union Pacific Railroad. Elk Mountain is at the right and the mountains in the distance belong to the Snowy Range of Colorado. In the group may be seen a male grouse strutting and wooing a mate.

Prairie Chicken. The courtship demonstrations of the prairie hen occur during the mating season, from March until early May. Before daybreak the male birds go through most surprising antics in their efforts to attract the females. The feather tufts on each side of the neck are erected, the 


\section{THE AMERICAN MUSEUM OF NATURAL HISTORY}

tail raised and spread, the wings drooped and the orangelike air-sacs on the side of its neck inflated. Then with a violent, jerking, muscular effort it produces the booming note which can be heard at a great distance. The scene represents a frosty morning on the United States Forest Reservation in western Nebraska.

Wild Goose. These birds arrive from the south before the ice leaves the lakes. They lay their eggs in early May in northern Canada. The sketches for the group were made at Crane Lake, Saskatchewan.

A Western Grebe Colony. These birds find ideal nesting places with other aquatic birds about the shores of Crane Lake, Saskatchewan. They walk with difficulty, and their homes must therefore be near the water. They are very shy and when setting leave the nest at the slightest alarm.

The Loon. The loon is famous for its skill as a diver, and there are stories of its being caught on "set lines" at a depth of from forty to sixty feet. It swims with great speed, and its call, a familiar sound on the northern New England lakes, is said by the superstitious to indicate the approaching death of some person in the vicinity. Though wintering on salt water, it nests on the fresh-water lakes.

Bird Rock. Here is reproduced a scene on Bird Rock in the Gulf of St. Lawrence. Seven species of birds are shown nesting in the group: common murre and Brünnich's murre, gannet, kittiwake gull, razor-billed auk, puffin and Leach's petrel. Cartier, who recorded his visit to the 


\section{THE AMERICAN MUSEUM OF NATURAL HISTORY}

island in 1534 , said that "these islands were as full of birds as any meadow is of grass ..." Return to the South Pavilion and enter the

\section{WEST CORRIDOR \\ Public Health}

\section{"All diseascs quenched by Science, no man halt or deaf or blind."}

Tennyson.

In a prominent position in the entrance way is a bronze bust of Louis Pasteur, the founder of modern bac:eriology, to whose researches we are indebted for the establishment of the germ theory of disease.

Directly in the foreground is a case containing a remarkable model of the flea, 120 times the length of the actual insect, in bulk the equal of $1,728,000$ fleas.

Near-by is a model of the body louse, the carrier of typhus fever, one hundred times the length of the insect itself, and adjacent and more noticeable than either of the above, a model of the fly, over twelve inches long and having the bulk of 64,000 flies. This is the finest model of its kind ever made and more than a year of constant work was required to construct it. The deadly work of the fly as a disease carrier and the practical methods by which it may be controlled are illustrated in adjacent cases.

At the left is an exhibit dealing with the natural source 


\section{THE AMERICAN MUSEUM OF NATURAL HISTORY}

of water supply, its contamination and pollution, storage, filtration, disinfection and purification.

A series of five large relief maps shows the development of the water supply of New York City.

Following are models and charts illustrating the improper disposal of sewage and how it can be avoided, the polluted waters of New York Harbor commonly used as bathing places and shellfish beds; models of the latest and most approved types of sedimentation tanks, filter beds and screens are included.

The shapes and relative sizes of many forms of bac:eria are illustrated, and window transparencies show how the more important bacterial forms appear under the microscope.

The ravages of the "Black Death," or bubonic plague, are well illustrated, with habitat groups of the rats and ground squirrels which serve as intermediate hosts for its microbes.

The mosquito, the carrier of malaria and yellow fever, has its section, as well as such other disease carriers as the tick and bedbug, and the Glossina, which transmits sleeping sickness.

Exhibits are also installed illustrating military hygiene and sanitation and the rations of troops in the field.

The exhibit is a portion of a comprehensively planned Hall of Public Health which ultimately will cover a much wider field. The exhibits now installed cover with reasonable completeness the topics of water supply, sewage disposal and insect-borne disease. 


\section{THE AMERICAN MUSEUM OF NATURAL HISTORY}

Near the stairway is a reading table where booklets on insect-borne diseases and public health problems may be consulted.

The collection of objects relating to the life and works of John J. Audubon is installed along the stairway. Continue to the

\section{SOUTHWEST WING}

\section{INDIANS OF SOUTH AMERICA \\ "Let observation with extensive view \\ Survey mankind, from China to Peru."}

Johnson.

Included in this hall are archæological collections from the ancient peoples who lived along the western and northwestern coasts of South America, and ethnological specimens from Indians who now live in Brazil, Paraguay and Argentina.

Near the entrance is a case containing gold, silver, platinum, copper and plated objects from Bolivia, Ecuador, Colombia and Peru, consisting of miniature human figures, vessels, implements and ornaments recovered from prehistoric graves and burial places.

On the immediate right is an exhibit of textiles from mummies and graves, together with examples of the raw material and weaving tools used in their manufacture. ${ }^{17}$ The fabrics made by the ancient Peruvians stand unrivaled

17 Peruvian Mummies-.10. 


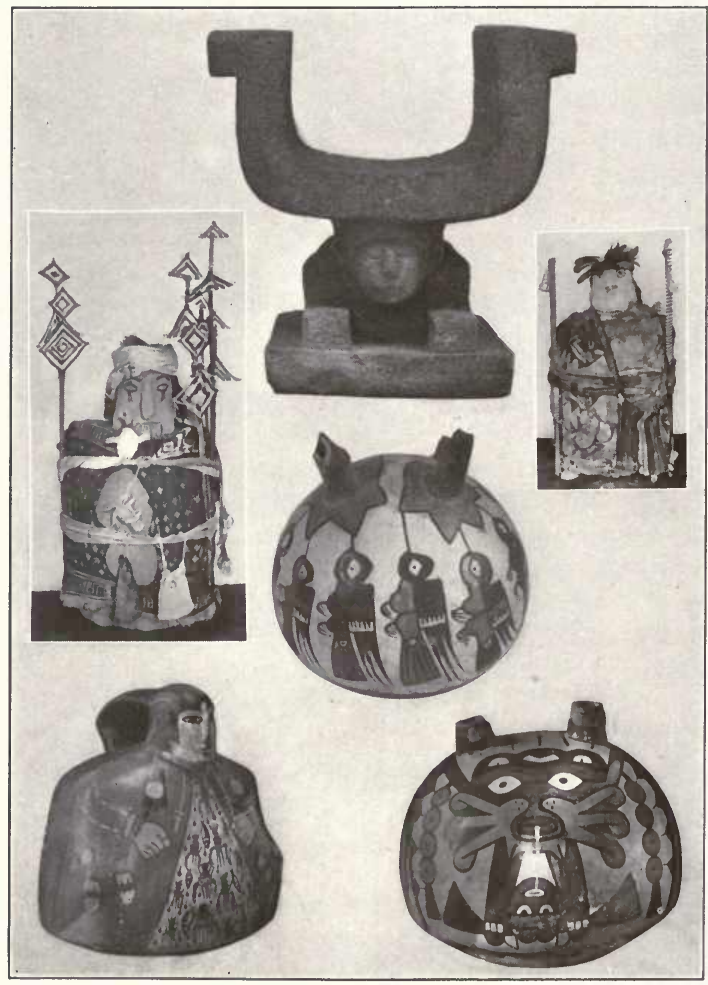

PERUVIAN MUMMY

STONE SEAT FROM ECUADOR

NAZCA POT'TERY

PERUVIAN MUMMY

88 


\section{THE AMERICAN MUSEUM OF NATURAL HISTORY}

among those of ancient peoples. They were acquainted with every style of weaving known to-day, and some of their tapestry, in its fineness of weave, beauty of color and design, has never been excelled. Underneath some exquisitely designed and colored ponchos is a specimen secured from a mummy bundle which is the best piece of plain tapestry in the collection and so far as known the finest example of this class of weaving in the world. There are 44 warps and between 280 and 300 weft threads per inch The ornamental stripe is in bobbin weave resembling modern Jacquard weave. At the left of the entrance is a case containing exhibits which illustrate the ancient burial customs of the Peruvians.

From Colombia is a large series of ancient terra-cotta stamps for printing cloth, pottery vessels and stone implements from ancient burial mounds, in both human and animal forms, together with a series of specimens illustrating the manufacture of tapioca.

From Ecuador is a great variety of pottery and unique stone seats, and in the exhaustive series of pottery, gold, silver and copper objects will be noticed original specimens which are figured by E. G. Squier in "Incidents of Travel and Exploration in the Land of the Incas."

Numerous interesting objects have been secured from Chile, the most conspicuous, however, being the mummy, in the case near the west end of the room, which was found in a copper mine near Chuquicamata, Chile. The body is that of an Indian who was killed while engaged in mining 


\section{THE AMERICAN MUSEUM OF NATURAL HISTORY}

copper. The tissues of the body have been preserved by the copper salts with which it was impregnated. In the same case are the implements he was using at the time of his death.

The pottery collections from Nazca and Ica in Peru and the islands of Lake Titicaca in Peru and Bolivia contain specimens remarkable for their unique forms, beautiful coloring and the attractiveness of the conventionalized designs.

On the south side of the hall is a series of skulls showing trephining, artificial deformation and pathological conditions, together with a number of skulls of normal form for comparison. Near-by is a collection of musical instruments from the Incas, comprising whistling jars, wooden and clay trumpets, gongs and bells of bronze and copper, gourd rattles, Panpipes and bone and cane flutes.

Differing in form and workmanship from the stone yokes in the Mexican collection, but without doubt closely related in use, are the stone collars to be found in the Porto Rican collection. Their use is problematical; by some authorities they are believed to he the regalia of sacrificial victims, of military heroes, of ecclesiastics or members of some privileged caste.

Attention is called to the exhibit of feather work and embroidery as represented by ponchos, belts, headdresses and other articles of dress distributed throughout the hall.

The gallery rail cases contain pottery, copper, gold and silver objects of many types and of peculiar designs, quipus 


\section{THE AMERICAN MUSEUM OF NATURAL HISTORY}

or knotted cords used to keep accounts, specimens of food and medicines, charms and implements. Grewsome evidence of the savage character of some of the existing tribes of the southern continent is given by the shrunken human heads in one of the cases. Adjoining is the

\section{SOUTHWEST PAVILION \\ Chinese and Siberian Collections \\ "Strange customs do thrive in foreign soil." \\ Schiller.}

The Chinese collection (on the left) illustrates the home industries and social life as they existed among the common people of China fifteen or more years ago, before the transformation of the empire from a patriarchal system of government into a modern commonwealth. Excellent examples of porcelain, terra-cotta and glass work in the form of ornaments, utensils and other articles of every-day use, together with objects of bamboo, palm fiber, cane and basketry, will be found in cases in the eastern end of the hall. Attention is directed to the horn lanterns made by welding softened layers of ram's horn into one mass. One case contains specimens of trays, boxes and panels inlaid with mother-ofpearl, ivory and various woods. Another case contains an exhibit of cloisonné and cinnabar lacquer work, shown by boxes, vases and trays, together with the material used in its manufacture. Other cases contain rugs, stone, wood 


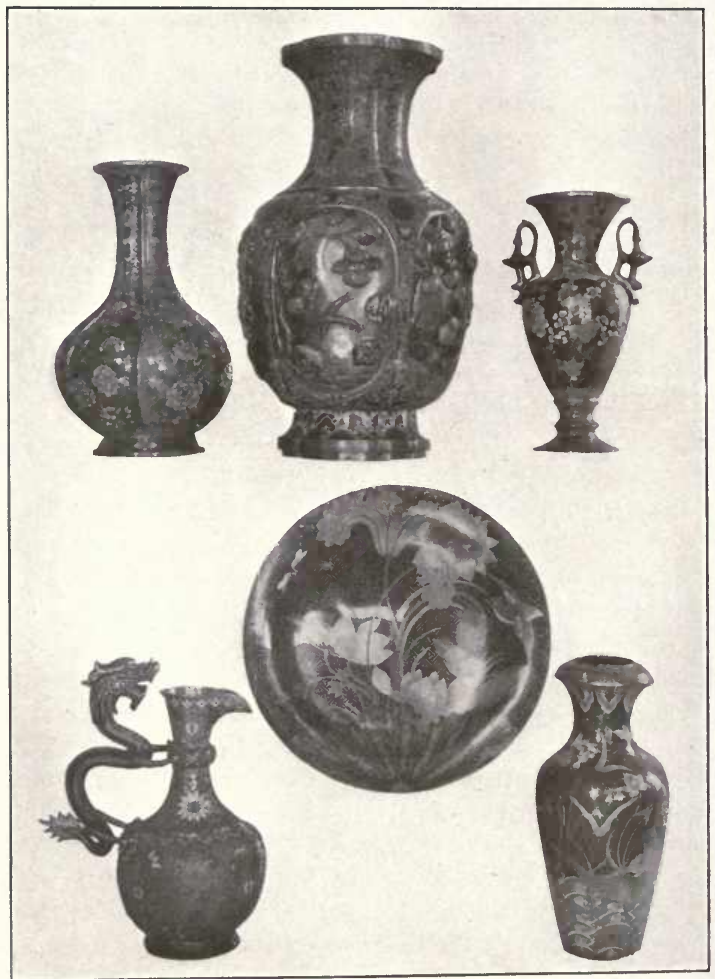

CHINESE CLOISONNÉ 


\section{THE AMERICAN MUSEUM OF NATURAL HISTORY}

and ivory carvings, decorative panels, household utensils and implements used in various occupations.

In the Tower Room is a rare and valuable collection of ancient pottery and bronzes, including mirrors, gongs, flower vases, libation cups, censers, bells, dishes and other objects from the Han Dynasty, 206 B.C. -220 A.D., Leuch'ao or Six Dynasties, 220-618 A.D., T'ang Dynasty, 618-905 A.D., Sung Dynasty, 960-1278 A.D., Ming Dynasty, 13681628 A.D., Last, or Manchu Dynasty, 1644-1912 A.D. From the Sung Dynasty, 960-1278 A.D., is a flower vase of 100 rings; only three of these bronze vases are in existence. From the Chou Dynasty, 1122-255 B.C., may be seen a temple bell inlaid with gold and silver, which when struck on the different knobs produces a different musical sound for each, and an unusual type of vessel in one casting, and from the Shang Dynasty, 1766-1154 B.c., a libation cup for offering wine to deceased ancestors.

Other specimens, illustrating the religious and home life, including a large image representing the Buddhist God of Mercy, which has eleven heads and forty-two arms, masks, images, altar sets, cosmetics, clothing, and tobacco and opium pipes, are installed in the cases on the west side of the hall.

From Siberia numerous specimens of clothing, weapons, household utensils, fishing and hunting implements, religious objects, carvings, musical instruments and toys illustrate the home and social life of the Chukchee, Koryak, Lamoot, Yukaghir, Yakut and Russianized natives. Among the speci- 


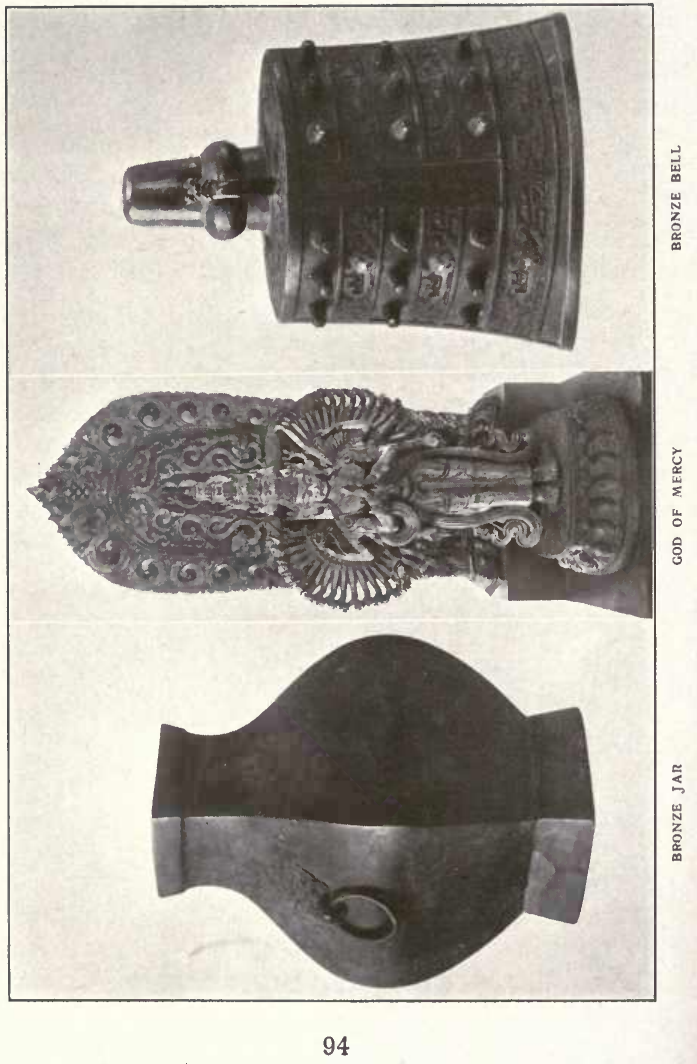




\section{THE AMERICAN MUSEUM OF NATURAL HISTORY}

mens obtained from these remarkable peoples, the visitor should examine the fishskin garments from the tribes of the Amoor River, decorated with elaborate conventionalized designs and geometric patterns, the beautiful bead and embroidered work, armor worn in warfare by the Koryak, utensils used in manufacturing kumyss by the Yakuts and the many remarkable pieces of inlaid fur work in the form of rugs and articles of dress. Metal work is also well illustrated by elaborately engraved objects of beaten silver, consisting of girdles, neck pieces, bracelets, earrings and silver-decorated saddles.

From the ceiling is suspended a walrus-skin boat made by the collectors of a Siberian expedition of this Museum and used by them for thirty-two days in traveling and transporting their material from Indian Point to Mariinsky Post, a distance of more than 1,200 miles. Enter the

\section{WEST WING}

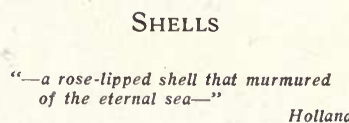

Holland.

Here the visitor will find a fairly exhaustive collection of marine, fresh-water and land shells, showing remarkable contrasts of form and great diversity of ornamentation in the nearly 25,000 species represented. 


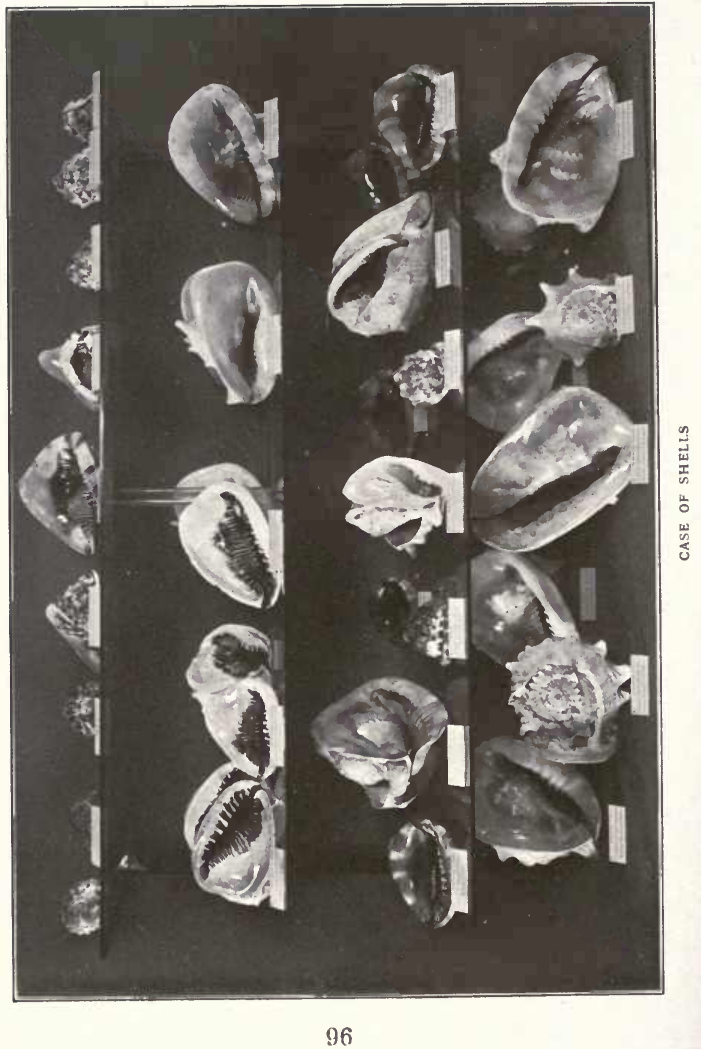




\section{THE AMERICAN MUSEUM OF NATURAL HISTORY}

Facing the entrance are shells of the giant clam, Tridacna gigas, measuring forty-three inches by twenty-seven inches and weighing 579 pounds. These were found near the Philippine Islands. They are used as holy-water fonts and bird baths. Formerly axe-heads and chisels were made from the thicker portions.

The wall cases on the south side contain a series showing the classification of mollusks; the eight table cases at the south and north ends of the hall, the land shells; the rail cases on the north, east and west, the bivalves, or mollusks with two shells, like the oyster, clam and scallop; the individual metal cases, univalves, those mollusks having but one shell or valve.

The south section of the rail cases, behind the "big shells," Tridacna, contains a series of unusually large and fine examples of the various species represented and also a typical collection of the cypræas or cowries.

At the rear of the hall is a number of shells showing ornamental and decorative uses, together with a number of deformed, abnormal and curious shells, the deformations of which are attributed to internal (physiological) or external (physical) causes. Other cases contain specimens illustrating the anatomy and habits of mollusks.

Maps and labels on the walls show the distribution and importance of the many families of mollusks exhibited. 


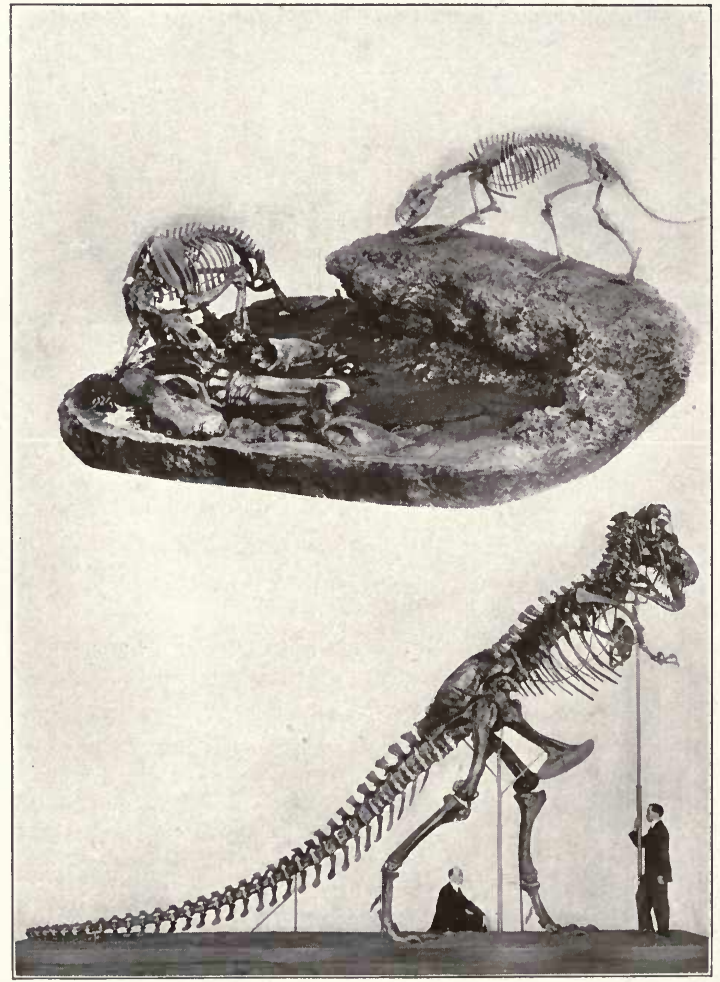

ASPHALT GROUP

TYRANNOSAURUS

98 


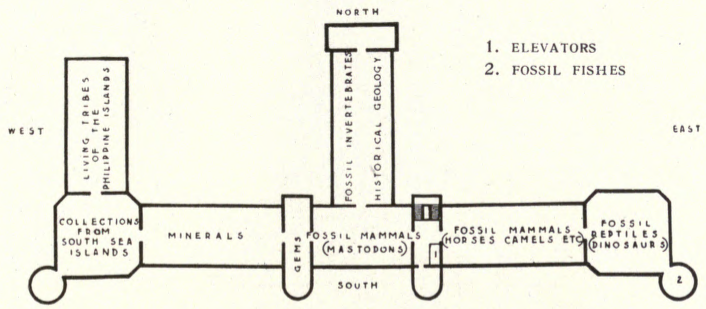

\section{FOURTH FLOOR}

\section{EAST CORRIDOR}

Immediately in front of the elevators is a wall case in which recently acquired specimens are installed. Near the stairway landings are fossil skeletons of the Mosasaur, or great marine lizard from the chalk beds of Kansas, and a number of Ichthyosaurs, from the slate quarries of Holzmaden, Germany. One of the Ichthyosaurs contains the skeletons of seven young, unborn, partly within and partly drifted out of the body cavity. 


\section{THE AMERICAN MUSEUM OF NATURAL HISTORY}

\section{SOUTHEAST WING}

\section{Hall of the Age of Mammals}

The skeletons in this and the adjoining halls are those of extinct mammals, most of which have been buried for so long that they have become petrified. In a few instances, however, such as the great lrish deer and mastodon, the skeletons are not petrified, and their present good condition is due to their complete burial for ages in peat bogs, in the frozen soil of northern Alaska or in deposits of asphalt. ${ }^{18}$

To give the visitor a clear idea of how these extinct creatures appeared in life, many of the skeletons have been removed from the matrix in which they were found, and have been mounted in lifelike attitudes; their probable appearance and habits are illustrated by water-color restorations, plaster models and descriptive labels. The arrangement of the specimens is intended to show the history or evolution of different races of animals, chiefly in North America.

In the first right-hand alcove is the largest and finest series of fossil skeletons, illustrating the Evolution of the Horse, ${ }^{19}$ possessed by any museum. Beginning with the earliest known ancestor of the horse, Eohippus, three hands (twelve inches) high, with its four complete toes on each fore foot and three on each hind foot, the successive stages

18 Animals of the Past-.35.

10 Evolution of the Horse-.20. 


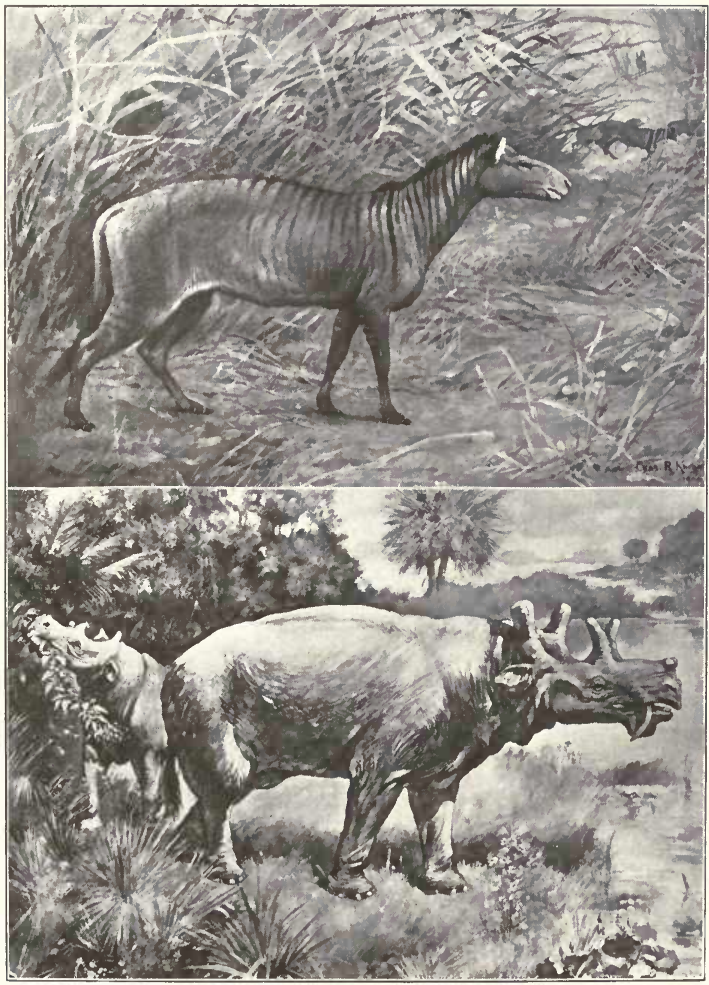

EOHIPPUS

UINTATHERIUM 


\section{THE AMERICAN MUSEUM OF NATURAL HISTORY}

of development or types of gradual elevation are represented by specimens of Orohippus, four hands high, Mesohippus, five hands high, Merychippus, nine hands high, Hipparion, ten hands high, and Equus scotti, the original North American horse, fourteen hands high. Although the remains of these fossil species of horse are abundant in North America in the latest geological formations, they all became extinct in the New World long before the discovery of America by the Spaniards. There are no traces of the horse in the Aztec history of America or in the knowledge of any of the South American peoples or even in the myths of the American Indian.

To typify the conquest of the horse by man, a skeleton of each, mounted in an erect position, is in a near-by case. The entire series is supplemented by excellent plaster restorations and water-color sketches.

Across the hall from the horse exhibit is a series of specimens showing the Evolution of the Camel, Deer and other cloven-footed animals. Next to the horses, the camels furnish the most striking series illustrating the evolution of a race of animals. The oldest known had four toes on each foot (probably, like other races, descended from a five-toed ancestor as yet undiscovered). In each successive formation, the race increased in size and gradually lost the side toes, consolidating the middle pair into a "cannonbone." An interesting exhibit is the large block containing five skeletons of a small extinct camel, found in a quarry near Agate, Nebraska. 
Next are the giant pigs, or Elotheres, and the mounted skeleton of a pigmy hippopotamus. Directly opposite will be found the Rhinoceroses, abundant in North America in former geological ages, represented by six complete skeletons and a large number of skulls of living and extinct kinds from North America, Europe, Asia and Africa. Adjacent are skeletons of Titanotheres, extinct gigantic animals somewhat resembling the rhinoceros in general form, found in the Oligocene formations of North America. The most recent, or final, stage of evolution of these animals is represented in the mounted skeleton of a specimen found in South Dakota, fourteen feet long, eight feet high and four feet broad. In the end wall case is a series of skulls, showing the stages of evolution, and plaster restorations of the heads of different genera are on the wall near-by.

The remaining alcove sections on the opposite side of the hall contain early Tertiary ancestors of the dogs, cats and other small mammals such as the rodents, marsupials and insectivores, the lemurs and monkeys, concluding with the exhibit of Uintatheres, extinct horned animals about the size of a rhinoceros, found fossil in the Eocene deposits of western United States.

In the center of the hall are especially interesting groups and specimens including the Asphalt Group, from Rancho La Brea, California, which will well repay attention. Other skeletons and skulls from this remarkable fossil deposit are shown in their appropriate places in the hall. 


\section{SOUTHEAST PAVILION}

Dinosaur Hall

"Thou speakest of times that long

have passed away."

Schiller.

In this hall are skeletons of fossil reptiles and fishes belonging to an older geological period than do the specimens in the hall previously visited. The dinosaurs were the great terrestrial vertebrates of their day, the Age of Reptiles $(3,000,000$ to $10,000,000$ years ago $)$, and there was a great variety of forms, but all had long hind limbs and long and generally massive tail. ${ }^{20}$

Dominant over other specimens is the amphibious dinosaur Brontosaurus, mounted in the center of the hall. This specimen is sixty-six feet eight inches in length, sixteen feet in height, and the animal is estimated to have weighed thirty-five tons. Beside it is a fossilized tree trunk, part of it carbonized or turned into coal, while the rest is silicified or turned into stone.

At the right is the large carnivorous dinosaur Allosaurus, mounted to represent the animal feeding on the carcass of a Brontosaurus. At the left of Brontosaurus stand two specimens of the duck-bill dinosaur Trachodon, and immediately in front of them is an extraordinary "mummified" specimen of the same species, in which a large part of the ${ }^{20}$ Dinosaurs -.25 . 


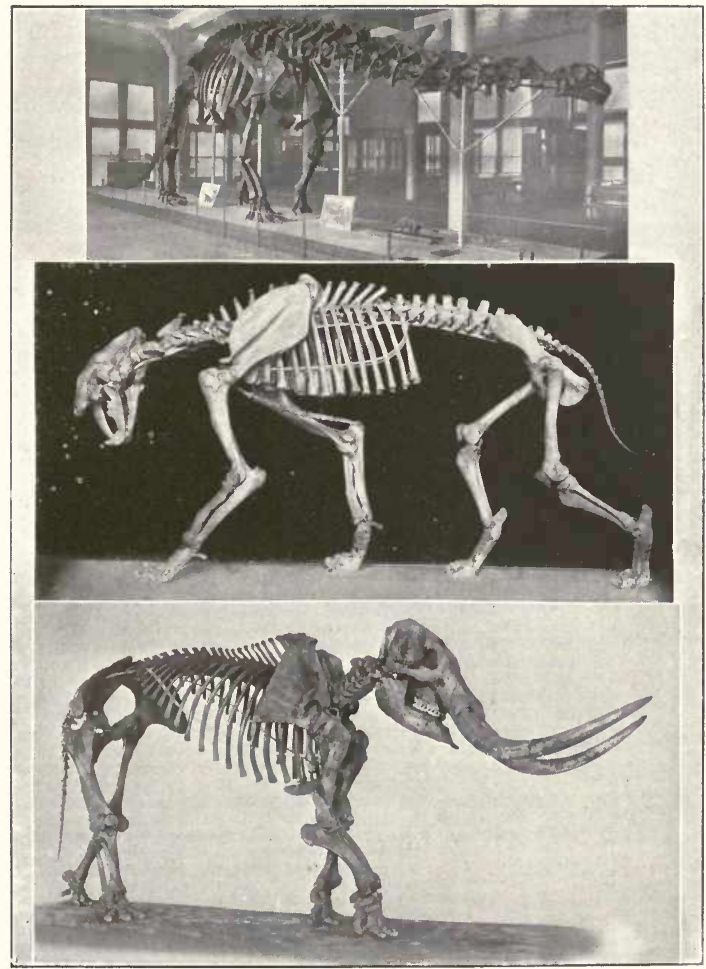

BRONTOSAURUS

SMILODON

WARREN MASTODON 


\section{THE AMERICAN MUSEUM OF NATURAL HISTORY}

skin, showing its texture, is preserved. Near-by are specimens of Pterodactyls, or flying reptiles, and a mounted specimen of a peculiar marine bird, Hesperornis regalis, from the Cretaceous of Kansas. This bird, like the more ancient Archceopteryx, which is the earliest bird known, had a row of small teeth in the jaws, a reminiscence of its reptilian ancestry, but it had lost the long reptilian tail which Archaoopteryx still preserved.

Immediately at the right of the entrance are the newly discovered and recently mounted skeletons from the Cretaceous of Alberta, Canada, of the crested duck-bill dinosaur Saurolophus, a herbivorous reptile, the helmet duck-bill dinosaur Corythosaurus, with its crested head similar to that of a cassowary, the horned dinosaur Monoclonius and the bird-like dinosaur Ornithomimus.

On the south side of the hall is the finest collection of fossil turtles in any museum, also specimens of finback lizards (Naosaurus and Dimetrodon), a specimen of Diadectes, a reptile with a solid-roofed skull, and one of Eryops, a primitive amphibian which inhabited the great swamps of the coal period and was one of the earliest land vertebrates. The latter represents the primitive amphibians, which are regarded as the ancestors of reptiles, birds and mammals as well as of the modern amphibians (frogs, etc.). These and other smaller specimens in the adjoining wall case are more ancient than the dinosaurs and lived at the time when the coal measures of Pennsylvania were being formed. 
At the eastern end of the hall are skeletons of smaller dinosaurs and several fine skulls of horned dinosaurs, Ceratopsia, from the Upper Cretaceous of Wyoming and Alberta, the most interesting example being that of Triceratops, seven feet in length, with its three large horns and heavy bony frill extending back and over the neck. In other sections will be seen a portion of a skeleton of Tyrannosaurus rex (king of tyrant saurians) and the remains of an armored dinosaur, Ankylosaurus.

Above the entrance to the Tower Room of the Southeast Pavilion, are the reconstructed jaws of a huge fossil shark in which the actual teeth are arranged as in the sharks of to-day, in banks or rows. This is the largest and most formidable fish, living or extinct, of which there is any record. The teeth were found in the phosphate beds of North Carolina, and after the jaws of live species were carefully measured, the model was prepared according to scale. It is known that a specimen, in which the largest tooth was one and one half inches in height, measured twenty feet in length, and that another, having teeth three inches in height, had a total length of forty feet. It therefore follows that the length of this Carolina shark, whose teeth measured six inches, was approximately eighty feet, comparing with the largest modern whales in size.

In cases at the right and left of the entrance are exhibits illustrating the forms, structure and development of typical recent fishes.

The exhibits in the Tower Room comprise the remains of 


\section{THE AMERICAN MUSEUM OF NATURAL HISTORY}

fossil fishes illustrating the rise and differentiation of the lowest vertebrates from the earliest (Upper Silurian) time (ending 20,000,000 years ago) to recent (Quaternary) time (ending 3,000,000 years ago). Most of the forms represented are North American and belong to five great divisions.

The first three cases confronting the visitor contain specimens of the armored fish-like forms, some of which were of huge size and armed with powerful teeth, or sharpened jaw blades. This form is best represented by the fish-like animal Dinichthys, displayed in the center of the room. Dinichthys lived about 20,000,000 years ago in the sea that existed on the site of the present State of Ohio, and was one of the most destructive and ferocious animals that ever lived in the sea. Although fish-like in appearance, it is regarded as belonging to a more primitive class of vertebrate animals. The head and front half of the body were protected by heavy plates of bone, and it had powerful jaws with "fangs" in front of and behind them, knife-like cutters which chopped against each other.

In the first alcove to the left is a "fossil aquarium," designed as an aid in interpreting the fossils in the adjoining cases, and it undoubtedly gives an accurate picture, since all the fishes shown were found in a single locality and in a single layer of Old Red Sandstone.

Proceeding to the right the visitor finds the sharks, rays and chimæroids, which are the earliest true vertebrates with cartilaginous skeletons and jaws, followed by the lung- 


\title{
THE AMERICAN MUSEUM OF NATURAL HISTORY
}

fishes, the fringe-finned fishes, shark-like in form and fins but with dermal bones and bony skeleton, and finally the spiny-finned fishes, or teleosts, which constitute the multitudinous forms of the present time and which include sturgeon, garpike, cod, herring, perch and the other common bony fishes. Return to the East Corridor and enter the

\section{SOUTH PAVILION}

\author{
Hall of the Age of Man \\ "Far must thy researches go \\ Wouldst thou learn the world to know." \\ Confucius.
}

Conspicuous in the center of the hall is a skeleton of the giant carnivorous dinosaur Tyrannosaurus rex (king of tyrant saurians), measuring forty-seven feet in length and standing nineteen feet in height. It can safely be said that Tyrannosaurus, which lived three million years ago, is the largest terrestrial flesh-eater of all ages. This specimen forms one of a group intended as the central exhibit of a new hall. Owing to lack of space, however, only one specimen can be mounted or exhibited at the present time, and this is placed temporarily in the Age of Man Hall, as there is not room in the Dinosaur Hall to show it properly.

On the left is a series of skeletons illustrating the evolution of the horse under the hand of man. In the exhibit are skeletons of the Shetland pony and draught horses, as 


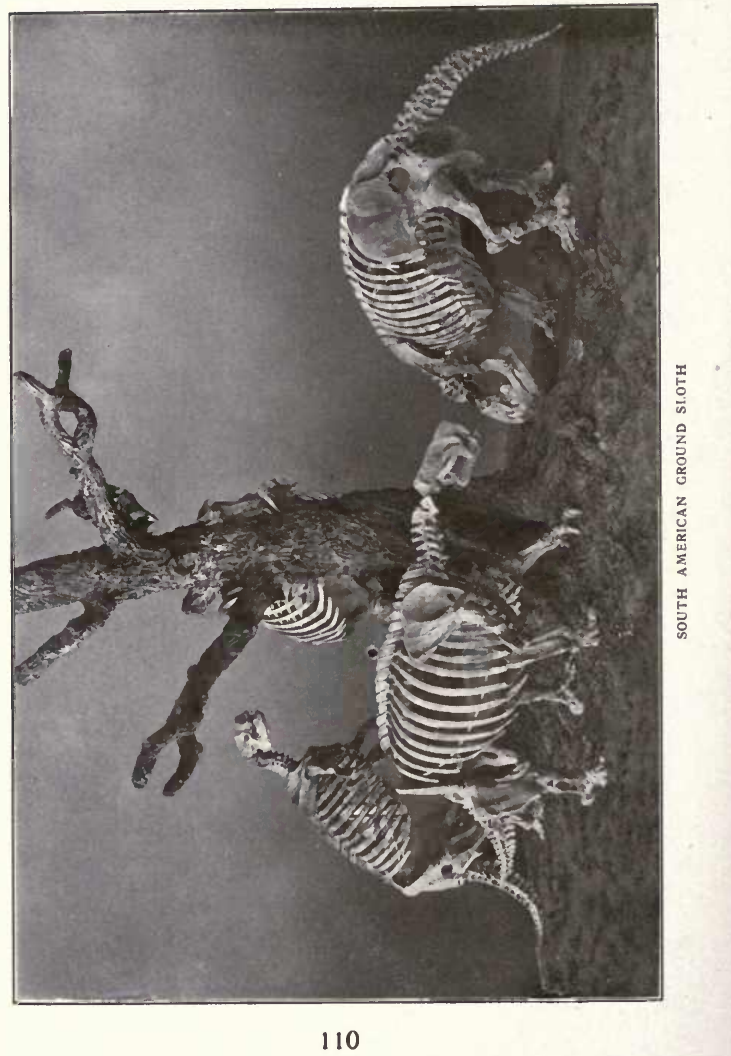




\section{THE AMERICAN MUSEUM OF NATURAL HISTORY}

well as those of the well-known race-horse "Sysonby" and the thoroughbred stallion "Nimr."

In the adjacent wall cases is an interesting osteological exhibit showing how the age of horses is determined through the growth and development of the teeth.

Beyond the horse exhibit are groups and individual specimens of fossil mammals from South America, the most prominent of which is the Giant Ground Sloth Group, ${ }^{21}$ and next to it the group of Glyptodons or tortoise-armadillos; skeletons of the rhinoceros-like Toxodon, of the camel-like Macrauchenia, the short-legged horse Hippidium and of the diminutive ground sloths that formerly lived in Cuba and Patagonia.

Near-by in the center of the hall is the great sabre-tooth tiger from South America. Numerous specimens of a smaller species of sabre-tooth tiger have recently been found in the asphalt deposits of California. (See the Asphalt Group in the Southeast Wing.)

At the immediate right of the skeleton of Tyrannosaurus is a number of A-shaped cases containing an exhibit designed to show the progress of discovery, especially in the last few years, with regard to the primitive races of man which inhabited Europe during and following the Great Ice Age. To illustrate the successive cultural states, there are reconstructions of the four principal ancestral types of man, i. e., Pithecanthropus or Ape-Man of Java, Eoanthropus or Piltdown Man, the Neanderthal Man (Homo neanderthal-

${ }^{21}$ The Ground Sloth Group-.05. 


\section{THE AMERICAN MUSEUM OF NATURAL HISTORY}

ensis), and the Cro-Magnon Man (Homo sapiens). In addition to the casts of the more important skulls, there are weapons and other implements, and drawings to illustrate further the appearance and habits of paleolithic man. These specimens served as subjects to illustrate the recent book of Professor Henry Fairfield Osborn, "Men of the Old Stone Age."

The remainder of the hall is occupied by a most comprehensive and instructive exhibit of mammoths, mastodons and elephants. ${ }^{22}$ The Warren Mastodon, found near New. burgh, New York, is the finest specimen of its kind ever discovered. The Evolution of the Mastodons and Elephants is illustrated by a series of skulls and separate teeth.

In the wall cases may be seen portions of skin and hair and other fragments of a mammoth found in Alaska. The plaster models of living and extinct elephants by Charles $\mathrm{R}$. Knight are worthy of examination. Proceed to the

\section{SOUTH CENTRAL WING}

\section{Geology and Invertebrate Palaontology}

\section{"Stones have been known to move and trees to speak." \\ Shakespeare.}

North of the Hall of the Age of Man, containing the mastodons and mammoths, is the Hall of Geology and Invertebrate Palæontology. At the entrance to the hall are two ${ }^{22}$ Mammoths and Mastodons-10. 


\section{THE AMERICAN MUSEUM OF NATURAL HISTORY}

hemispherical forms which illustrate the six stages in the geographical development of the North American continent. The stages represented are the Upper Cambrian, Middle Devonian, Upper Triassic, Lower Cretaceous, Upper Cretaceous, Upper Oligocene. On each model the present outline of the North American continent has been superimposed upon that of the ancient lands and seas. They differ widely from the modern outlines in all instances except the Oligocene, which is more nearly like the present map. These models represent the first attempt at restoring the relief of the ancient lands on a curved surface.

The desk cases down the center of the hall contain the types and figured specimens used by James Hall, R. P. Whitfield and others in the original description and naming of species. Most of the American specimens are from New York State, although there are many from the Middle Western States. The type series, as it is designated, is arranged biologically under each period, beginning with the oldest fossiliferous period, the Cambrian, at the entrance. Geologists regard this series, with its 10,000 specimens, as the largest and most valuable collection of fossil invertebrate types in America. Toward the far end is a beautiful collection of fossil sponges from northwestern Germany.

The specimens in the upright cases, at the east or righthand side, are being arranged to illustrate the development and relationship of the more common species of plants and animals of past geologic times. In the first case are striking examples of carbonization and silicification of woody 


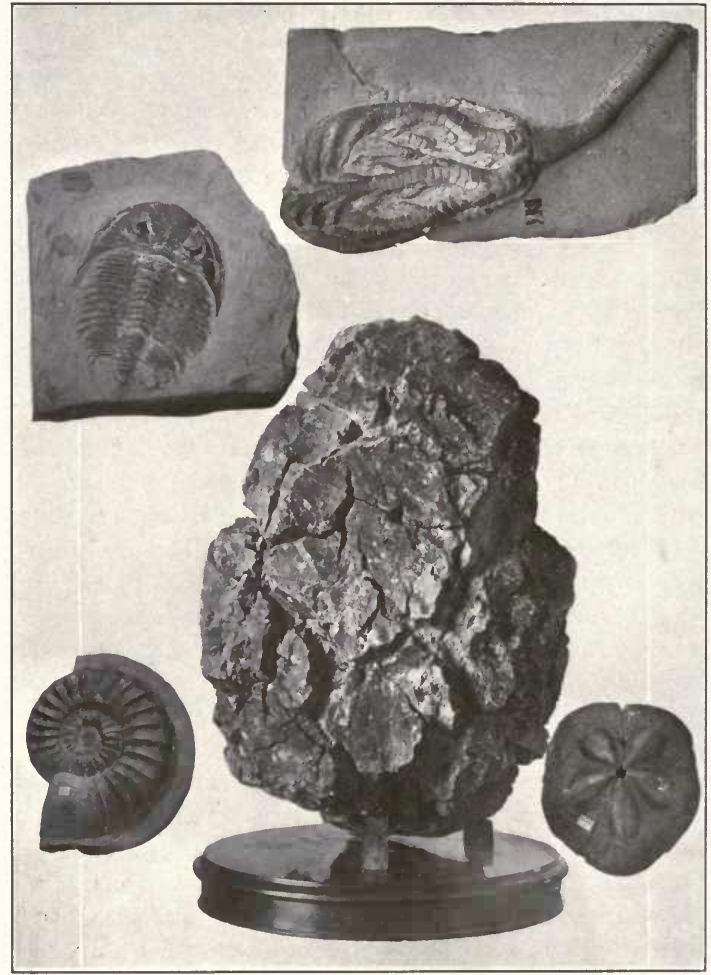

TRILOBITE

CRINOID

AMMONITE

VOLCANIC "BREAD-CRUST"” BOMB 


\section{THE AMERICAN MUSEUM OF NATURAL HISTORY}

fiber, ranging from Devonian to Recent in age. A large stump, with part of the roots, of a carboniferous tree from an anthracite coal mine under Scranton, Pennsylvania, is in the first alcove. Near-by are many typical fossil leaves arranged systematically.

In the remaining upright cases is a select series of fossil specimens illustrating the species of the various biologic groups of the animal kingdom. These specimens are also arranged systematically.

The specimens on the left or west side of the hall are being arranged to illustrate the order of superposition (one placed above the other) of the various beds of sedimentary rock in the earth's crust as well as the provincial distribution of the fossils and rocks during the various stages of a period. The series begins at the south (near the entrance) with the Archæozoic, which are the lowest and oldest of all rocks and contain no fossils. These are followed by the Proterozoic rocks, which contain scant remains of life. Beginning with the Cambrian period and continuing through the Ordovician, Silurian, Devonian, Mississippian, Pennsylvanian, Permian, Triassic, Jurassic, Comanchian, Cretaceous, Tertiary and Quaternary periods, life shows marked evolution and extinction in some groups and but little change in others. When it is stated that it took at least $30,000,000$ years to deposit the sedimentary beds from the Cambrian to the Present and that life existed throughout this time, the length of life of man sinks into insignificance. 


\section{THE AMERICAN MUSEUM OF NATURAL HISTORY}

In three of the alcoves on the east side is the general collection of meteorites, which is one of the largest and most representative in this country, containing specimens of from 500 to 700 falls and finds that are known throughout the world. The "stone shower" that fell near Holbrook, Arizona, in 1912 and the entire mass of Ysleta, 1914, are the most striking recent acquisitions.

In another alcove, on the east side, is a desk case containing a series of rock specimens from Manhattan Island. This is arranged geographically from south to north and shows the character of the rock upon which New York City is built. In the northeast corner of the hall is a model of the Copper Queen Mine and a series of ores and other specimens from the Bisbee-Warren copper district in southern Arizona.

On the opposite or northwest corner is a display of caves and cave material, including a reproduction of part of a cave that was discovered in 1910 in mining operations at the Copper Queen Mine, and alongside is a reproduction of a chamber in Weyer's Cave, Virginia.

Conspicuous in the central portion of this section is a great mass of copper ore about three feet square by five feet high, weighing three and one half tons. It contains more than a ton of pure copper, besides some silver and gold. That portion in streaks of beautiful blue is azurite, and that in green, malachite. 


\title{
WEST CORRIDOR
}

\author{
Gems and Precious Stones \\ "Rich and rare were the gems she wore, \\ And a bright gold ring on her wand she bore."
}

Moore.

This splendid series of gems and precious stones, together with the Bement collection of minerals in the adjoining hall, was presented to the Museum by J. Pierpont Morgan, a founder and Trustee of the institution. It includes many large and rare forms of cut and uncut gems, some of which cannot be duplicated.

In the wall cases are fine examples of quartz, gypsum, rubellite, jade, calcite, opal, and of lceland spar which makes a double refraction of light rays, thereby causing objects seen through it to appear double.

The collection is especially remarkable for its many unique specimens. Among these may be mentioned the most perfect large sapphire known, a Babylonian axe-head of banded agate, 4,000 years old, and a wonderful series of sapphires, blue, pink, salmon and brown. There is also a magnificent series of beryls, a large series of tourmalines, and an immense section of jade from a boulder, but so thin that it measures not more than an eighth of an inch through. There is also in the collection a great hyacinth with the portrait of Christ engraved on it, the gift of a Vatican cardinal to a friend. 


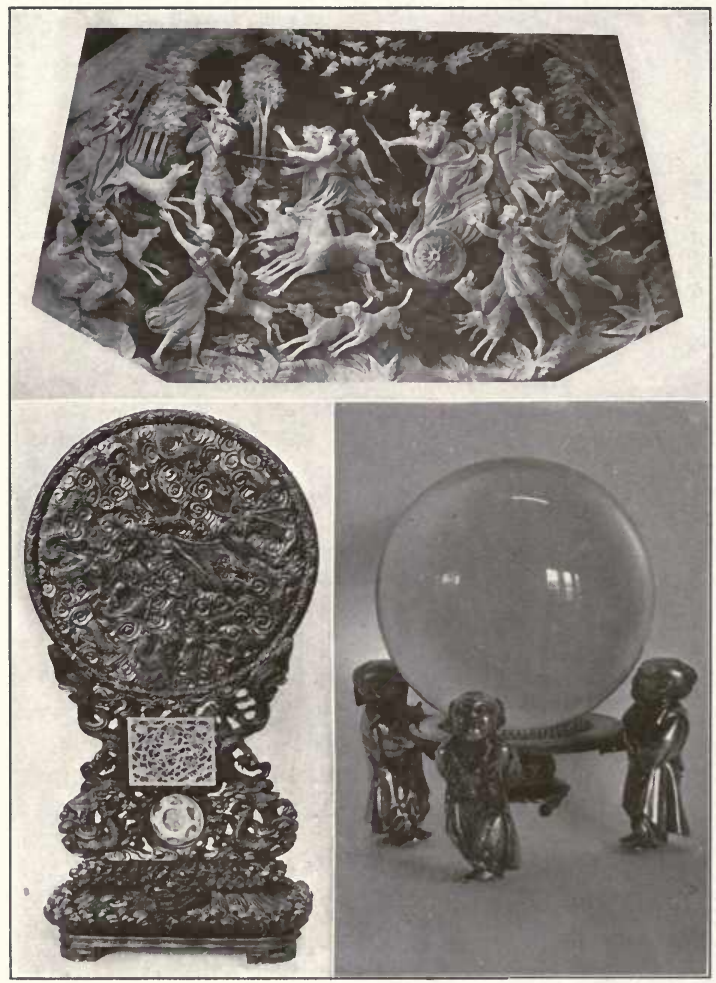

CAMEO CUTTING

118 


\section{THE AMERICAN MUSEUM OF NATURAL HISTORY}

The collection numbers more than 2,000 gem stones, objects of precious stone and nearly 2,500 pearls. A partial graduation in importance and value is obtained by the arrangement of the gems beginning with the diamond at the extreme south and passing north case by case, in each instance the raw material or uncut gem being placed in the center of the case and the cut material around it.

In its entirety the collection is the most extensive and carefully selected display of rough and cut stones in existence, and it must always stand as a wonderful monument to the man who thus generously enriched the American Museum. Proceed to the

\section{SOUTHWEST WING}

\section{Minerals}

Adjoining the Gem Hall is the Southwest Wing or Hall of Minerals. ${ }^{23}$ At the entrance to the hall is the case containing recent acquisitions. The general collection consists in the main of the well-known Bement collection and includes representative species of the known minerals of the world. Although representing a large number of rare species, the chief fame of the collection rests upon the variety of forms representing the commoner minerals and the exceptional perfection of the specimens. The more attractive specimens are contained in the cases arranged down the

23 The Collection of Minerals-.05. 


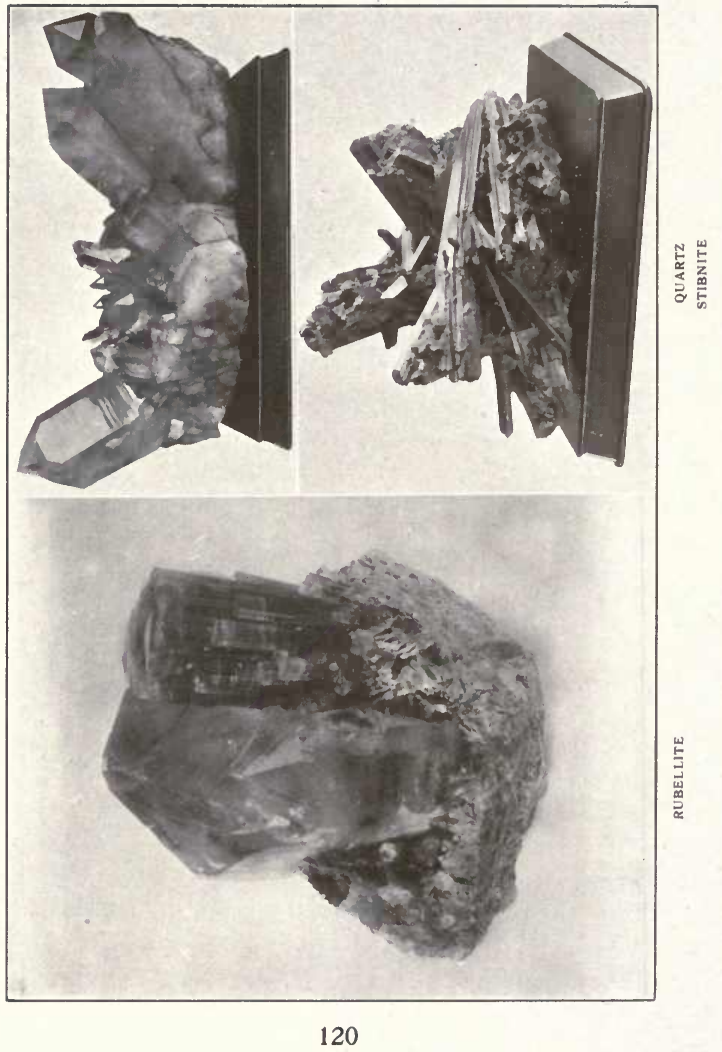




\section{THE AMERICAN MUSEUM OF NATURAL HISTORY}

center of the hall. The remainder are arranged according to the classification of minerals.

In the first cases on the right the visitor will find models illustrating the various types of crystallization. In the lefthand wall case are some unusually handsome specimens of agate and opal, and in a near-by table case are models of some of the most famous of the world's diamonds, including the wonderful Cullinan diamond, the original of which was valued at three million dollars, and the largest so far discovered. Continue to the

\section{SOUTHWEST PAVILION}

\section{Collections from the PaCific Islands}

Near the entrance is a large Hawaiian feather cape made from the red and yellow feathers of a honey-sucker. Such capes formerly were worn by the kings and chiefs of Hawaii. In the center of the hall is a group representing a Tahitian priest in the firewalking ceremony. The explanation of the fact that the heated rocks do not cause injury to the bare feet is that the porous basalt is a bad conductor of heat, so that while the stones appear to be of forbidding heat the upper surface is not sufficiently hot to cause discomfort to the tough-soled natives.

On the left of this group is another showing a native Tahitian engaged in making kava, a stupefying beverage prepared from the roots of the pepper plant, Piper methys- 


\section{THE AMERICAN MUSEUM OF NATURAL HISTORY}

ticum, and another weaving roof coverings of pandanus; on the right is a group representing a native Tahitian grating cocoanut and another making fire by the primitive method characteristic of the Polynesians, by means of the fireplough.

With the exception of a small Australian exhibit, consisting of boomerangs, stone implements and ceremonial objects, the entire hall is devoted to collections from Polynesia, Melanesia and Micronesia.

The eastern half of the hall contains objects from Samoa, Hawaii, Marquesas, Cook, Gilbert, Savage, Marshall, Caroline and Tonga Islands, including wooden images, tapa cloth, weapons, musical instruments, garments, ornaments of dress and models of canoes. Especially interesting in the northeast corner of the hall are the suits of armor and the unique series of weapons from the Gilbert Islanders. The armor is woven of cocoanut fiber and the weapons are set with sharks' teeth. The old mariner's chart, composed of straight and curved sticks to denote the course of the waves while small pebbles represent the atolls, secured from the Marshall Islanders by the late Robert Louis Stevenson, will also repay attention.

In the southeastern section of the hall are fine examples of tapa cloth, canoe models, household utensils, garments, kava bowls, necklaces and weapons from Samoa and Fiji. Among the most valuable specimens is the model of a bure or temple, while the cannibal forks and flesh racks are probably the rarest and most exceptional in museum collections. 


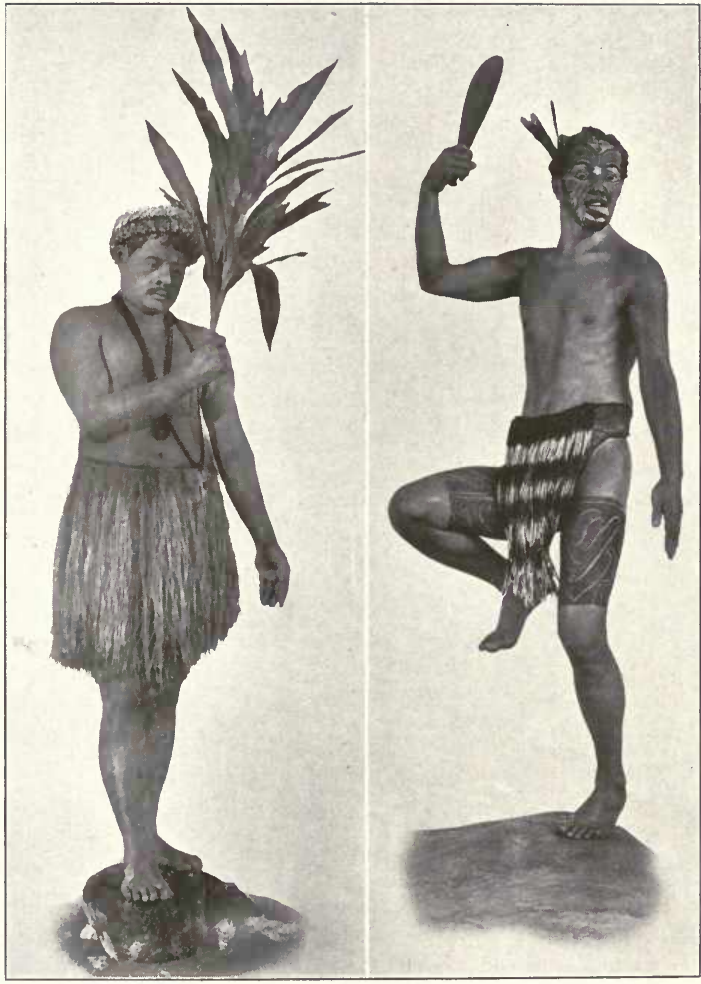

TAHITIAN FIRE WALKER

MAORI WARRIOR

123 


\section{THE AMERICAN MUSEUM OF NATURAL HISTORY}

In the front of the Tower Room stands a life-size cast of a Maori warrior, posed in an attitude of defiance, on the largest block of jade in any museum in the world. Within the Tower are specimens of Maori carvings, clothing and tools, together with a remarkable collection of the tattooed heads of ancient Maoris. The heads are thirty-five in number and illustrate all the different styles of the art of tattooing as practised among these peoples prior to 1831 , when it was forbidden by the British Government.

The remainder of the hall contains specimens from the Melanesians of New Hebrides, New Caledonia, New Ireland, New Britain, Admiralty, Solomon and New Guinea Islands. In these exhibits the sacred carvings and masks from New Ireland and the grotesque shields and ceremonials from New Guinea are especially noteworthy. Enter the

\section{WEST WING}

\section{Philippine Islands}

Through the center of this hall will be found, first the model of an Igorot woman weaving on a native loom, next the model of a typical house of the better class, then a fullsized outrigger canoe, a water filter with jars and rack and lastly one of the tree-houses of the Lake Lanao Moros.

The visitor should now examine the exhibits on the right or east side of the hall.

The Negrito collection is first. These pygmy peoples are believed to be descended from the first inhabitants of the 


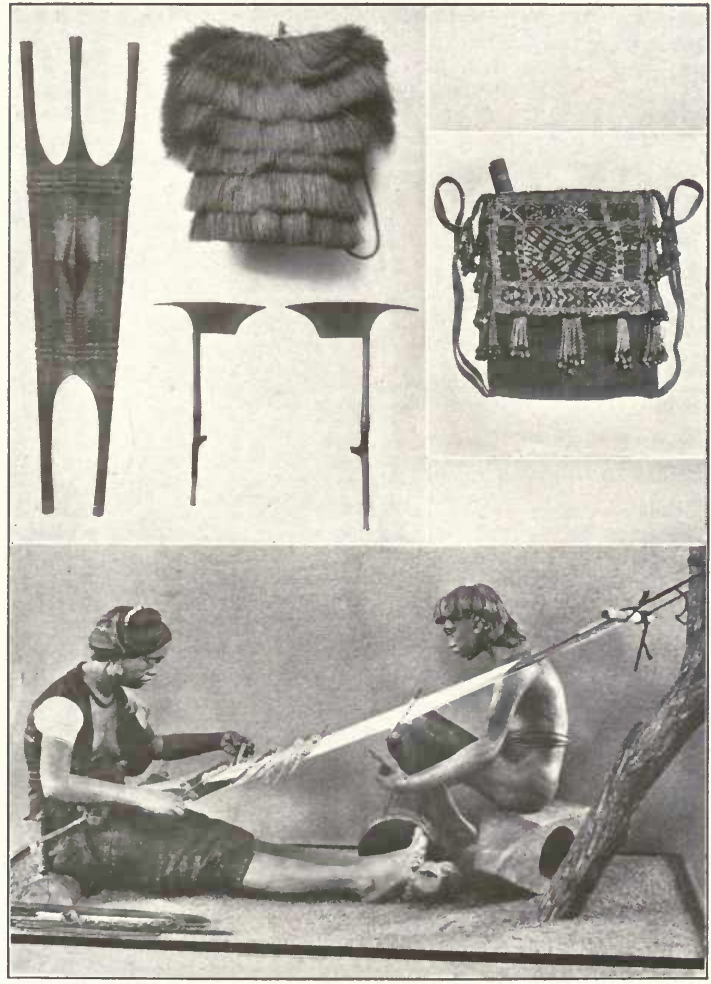

IGOROT HEAD-AXES, SHIELD AND BASKET

BAGOBO BAG

IGOROT WEAVER 


\section{THE AMERICAN MUSEUM OF NATURAL HISTORY}

islands. They are true savages, depending for food upon the chase, neither living in villages nor building stable huts, but roaming through the mountains in small groups of a few families each. They are fleet of foot, and their usual weapons are a lance of bamboo, a palm wood bow and a quiver of poisoned arrows. They use as ornaments bamboo combs, feather headdresses, rings and bracelets of brass or copper, and braided leg bands of hog bristles, which are supposed to give them endurance and make them fleet of foot. They scarify the body, and such scars are their most highly valued adornment. For household utensils they have only a few cocoanut cups or sea shells, rude boxes, the primitive fire-saw and a few crude musical instruments.

Then follows a display of specimens from the Mangyan, Tinguiane, Manobo, Tirurays and Igorot tribes. Of these the collection from the Igorot is the largest and most representative.

The Igorot form the largest family inhabiting Luzon and include the Dadayag, Kalinga, Ibelao, Ipukao and numerous other tribes bearing various local names. They constitute a fine race of agricultural, head-hunting barbarians. They are copper-colored and have high cheek-bones, flat nose and thick lips. Their hair is straight, black and in many areas is worn long.

The men are exceedingly well developed and possess great strength and power of endurance. The women are well formed and as erect and graceful as any women in the Orient; their dress varies from a mere apron of leaves to a handsome jacket and skirt with stripes of blue, crimson 


\section{THE AMERICAN MUSEUM OF NATURAL HISTORY}

and white. Tattooing is common among both sexes. With the men there are two chief motives in tattooing: first, it gives a man's war record, telling that he has taken a human head; second, it is esthetic. The esthetic is the governing motive for women's tattoo. The Igorot commonly manufacture iron and steel bolos, spears and battle axes, also earthenware and a great variety of cloth of native cotton and of tree-bark fiber. Their warlike proclivities are represented in a number of specimens of head-axes and headhunting baskets. The name given to these baskets is a misnomer, as they are used chiefly for carrying food and articles of personal property. The musical instruments of the Igorot consist of gongs and clappers; their ornaments are generally of brass and copper. The most highly prized ornament, however, is the shell of the pearl oyster, Meleagrina margaritifera, which the Igorot obtain in trade.

Adjoining the Igorot collections is a series of specimens from the Samal and Sulu Moros, who constitute the Mohammedan population and are the latest comers to the islands. Their conversion to Mohammedanism by Arabian missionaries in the twelfth century was undoubtedly the means of making them dominant everywhere south of the Visayan Islands. They were the "Norsemen" of the Orient, adventurous navigators and fierce fighters. Their history is the climax of Malay piratical power, which was felt for centuries for a thousand miles both north and south of their strongholds in Jolo. Their warlike character is indicated by the predominance of krises, both straight and curved, spears and shields. Their domestic life is represented by 


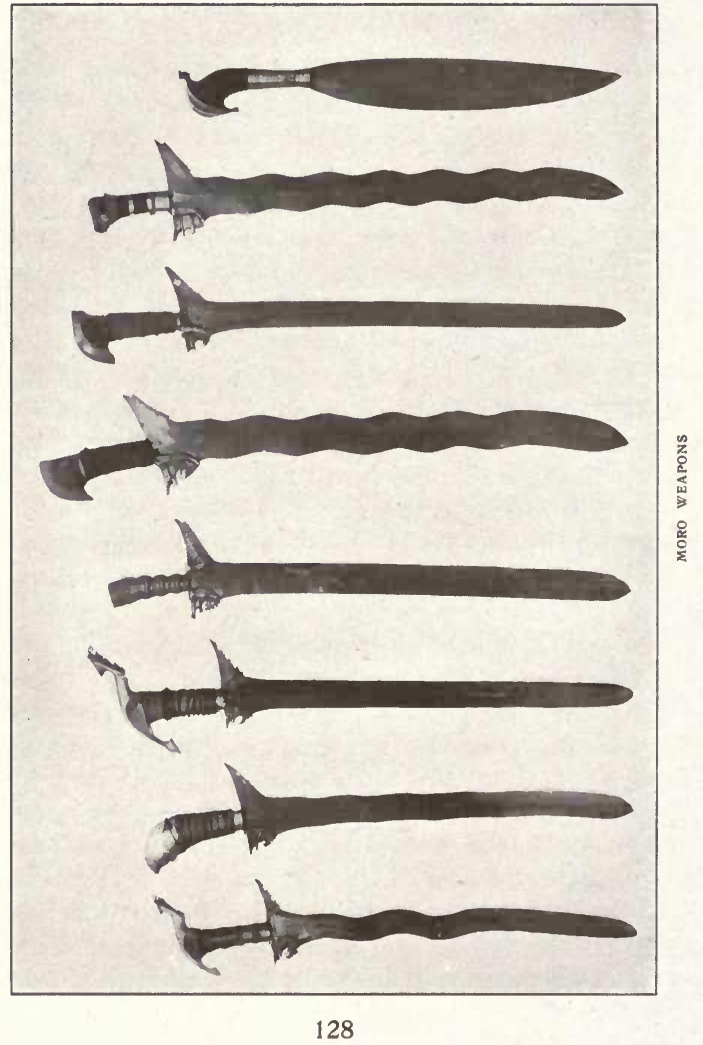




\section{THE AMERICAN MUSEUM OF NATURAL HISTORY}

examples of pottery and basketry; their musical attainments by gongs, clappers and xylophones; their skill in metal work by lime and betel-nut boxes, vases and jars and by their weapons.

Adjoining the Moro collection are two cases showing the knives and blow-guns of the peoples inhabiting the Islands of Sumatra, Celebes and Java.

The western side of the hall is occupied entirely by a most elaborate collection from the Bagobo of southern Mindanao. This tribe, numbering a few thousands, forms one of the group of pagan Malay tribes living in villages back from the west coast of the Gulf of Davao. They are a people of singular beauty with clear, golden brown skin, earnest wide-open eyes and mobile faces changing from deep seriousness in repose to sparkling vivacity in conversation.

In dress both the men and the women display unusually good taste. The men wear short trousers and open jackets and carry richly beaded bags on their backs. The women are generally clad in scant-bodied, scarlet-sleeved waists and straight skirts, woven in pictured patterns. They generally adorn their heads with bright colored handkerchiefs, wear ivory and inlaid plugs in their ears and around their necks hang pendants of finely carved seeds, braided beadwork and strung flower petals. Attached to their carrying bags and dresses is generally a number of small bells. Both men and women chew the betel nut, and specimens of their lime and betel-nut boxes may be seen in the collection. 


\section{THE AMERICAN MUSEUM OF NATURAL HISTORY}

In weaving, the Bagobo woman has attained high skill in technique and continues to produce patterns which she has learned from her mother or from her grandmother. Their clothing is usually woven from hemp fiber. In the collection are excellent examples of their weaving art, including those having complex figures made by tying the warp before the weaving. In this instance the fiber is stretched on a long frame of bamboo, and to make a pattern the woman picks out a cluster of strands at varying intervals, binding each into knots with short lengths of hemp. So tightly are these clusters bound that when the whole warp is afterward dyed, no color can penetrate to the parts thus tied.

The Bagobo are fond of music, and many kinds of musical instruments are shown in the collections. Firm in their friendships, they are quick to resent an injury or wrong. They are fierce in warfare and frequently decapitate their enemies.

As a decorative feature of the hall, but one which also tends to give unity and meaning to the exhibit, there is installed a wainscoting of native woods, which constitutes one of the largest and most authoritative collections in the world.

Other features are the examples of pottery and basketry upon the tops of the cases, and the framed mats, many of which are of beautiful design, arranged as a frieze.

Owing to lack of exhibition space, it is impossible to display the large collections (now in storage) from the Christian tribes inhabiting the islands. 


\section{FIFTH FLOOR}

The fifth floor is occupied by the Administrative Offices, the Offices and Laboratories of the Scientific Departments and the Library, which contains more than 70,000 volumes on natural history, anthropology and travel.

There are in the Library more than 15,000 volumes in zoölogy; 3,500 volumes in entomology; 2,000 volumes in conchology; 2,500 volumes in anthropology, including many of the older works relating to the North American Indian; 3,500 volumes in geology, enriched by the library of the late Professor Jules Marcou; a collection of 5,000 volumes in palæontology, in the main composed of the Osborn Library of Vertebrate Palæontology, and an unusually complete collection of more than 25,000 volumes of natural science periodicals.

The Reading Room of the Library is open free daily, with the exception of Sundays and holidays, from 9 A.M. to 5 P.M., to all who may wish to consult the books.

In addition to the exhibits which the Museum displays, it maintains a Department of Public Education which cooperates with the Board of Education of the City in a most comprehensive manner, by supplying to the schools lan- 


\section{THE AMERICAN MUSEUM OF NATURAL HISTORY}

tern slides and loan collections of nature study material and by giving lectures on Geography, History and Natural Science at the Museum and in the schools. Coöperation with the public libraries and provision for the blind are features of the Museum's work which are receiving special attention and are of more than passing interest. Without doubt there are no children who appreciate a visit to the Museum and an opportunity to handle the specimens more than do the blind children from the public schools and the immediate vicinity. This policy is making the Museum a growing educational force in the community. 


\section{THE NEW YORK AQUARIUM}

The New York Aquarium is the largest in the world, both as regards size of building and number and variety of specimens exhibited. It is situated in Battery Park at the foot of Broadway and may be reached by all elevated, surface and subway lines running to South Ferry. The nearest elevated station is Battery Park; the nearest subway station, Bowling Green.

Erected as a fortress by the United States Government in 1807, the outer walls of the building are nine feet thick and contain thirty gun embrasures; the walls of the old ammunition rooms are fifteen feet thick. The fort occupied a mole 300 yards from the mainland, but the intervening space was later filled in. In 1823 it was ceded by Congress to the City of New York and became an amusement hall known as Castle Garden, and later an opera house, where, in 1850, Jenny Lind made her first appearance in America. From 1855 to 1891 , the building was used as an immigration station, and in 1896 it was opened as an aquarium by the Department of Public Parks of New York City. In 1902 its management was transferred to the New York Zoölogical Society, a private scientific association which has 


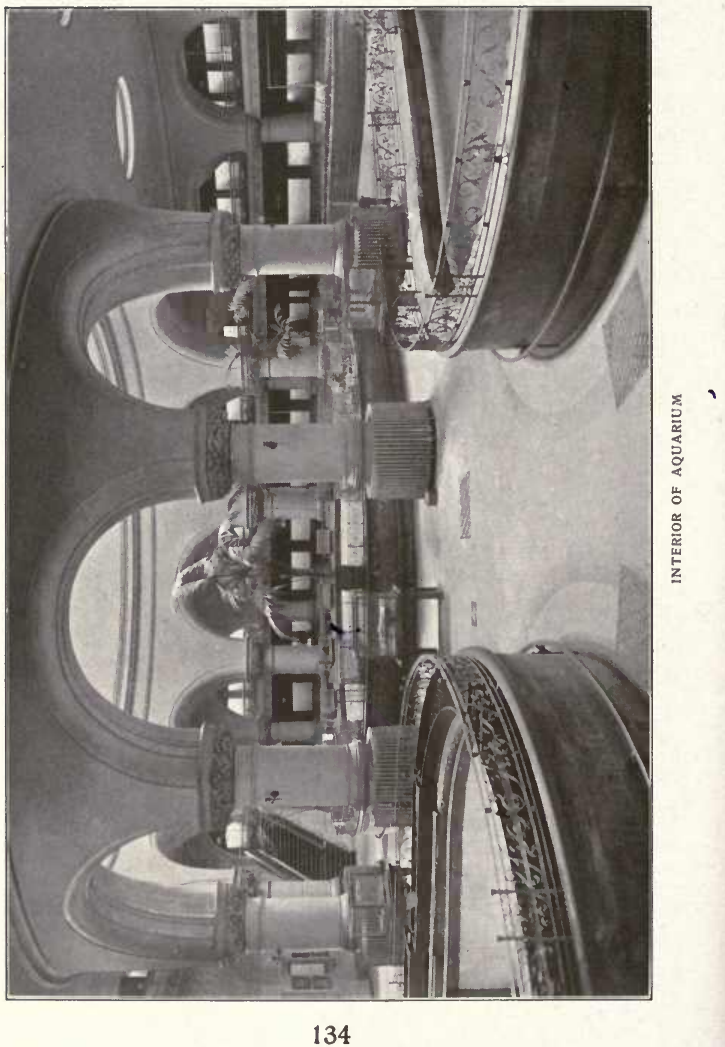




\section{THE NEW YORK AQUARIUM}

complete control of the institution and is responsible for its status as a museum. The annual maintenance fund of the Aquarium is provided by the City of New York. The exhibits are provided by the New York Zoölogical Society.

The Aquarium is open free every day in the year: 9 A.M. to 5 P.M., from April to October, and 10 A.M. to 4 P.M. from November to March.

The building is circular in form with a diameter of 205 feet. Seven large pools, containing turtles, crocodiles, large fishes and marine mammals, occupy the main floor, and a series of large, well-lighted wall tanks - thirty to forty around the main floor, and fifty to sixty on the gallery above-present to the visitor a comprehensive view of American fishes, including marine, fresh-water, tropical and northern species.

The equipment includes facilities for heating sea water in winter for the tropical fishes; for cooling fresh water in summer for the natives of mountain lakes and rivers; for pumping and filtering brackish water from New York Bay for the large floor pools, and for maintaining a reservoir of pure sea water for the salt-water wall tanks. There is also an air compressor for supplying extra aëration to all tanks when necessary. 


\title{
THE NEW YORK AQUARIUM
}

\section{MAIN FLOOR}

\author{
"Oh! the gallant fisher's life \\ It is the best of any; \\ -Tis full of pleasure, void of strife, \\ And 'tis beloved by many."
}

Walton.

The center of the main floor is occupied by a tank thirtyseven feet across and seven feet deep, devoted to porpoises and dolphins, closely allied warm-blooded mammals belonging to the whale family.

The six other pools around this floor, proceeding from left to right from the main entrance, contain:

1. Large marine turtles. Of these the green turtle of the Atlantic coast from New York southward is the most important of the sea turtles and the one commonly used for food. It attains a weight of 1,000 pounds or more. The loggerhead turtle, of the Atlantic coast from New York to Brazil, also attains great size and weight, but is not a food species. These large turtles have lived many years in the Aquarium.

2. Fresh-water turtles. In this pool are the diamond-back terrapin, the finest of edible species, the Cumberland turtle, the wood turtle, Lesueur's terrapin, the chicken turtle, several large specimens of the soft-shelled turtle and others.

Young alligators and bullfrogs also find a place here. 


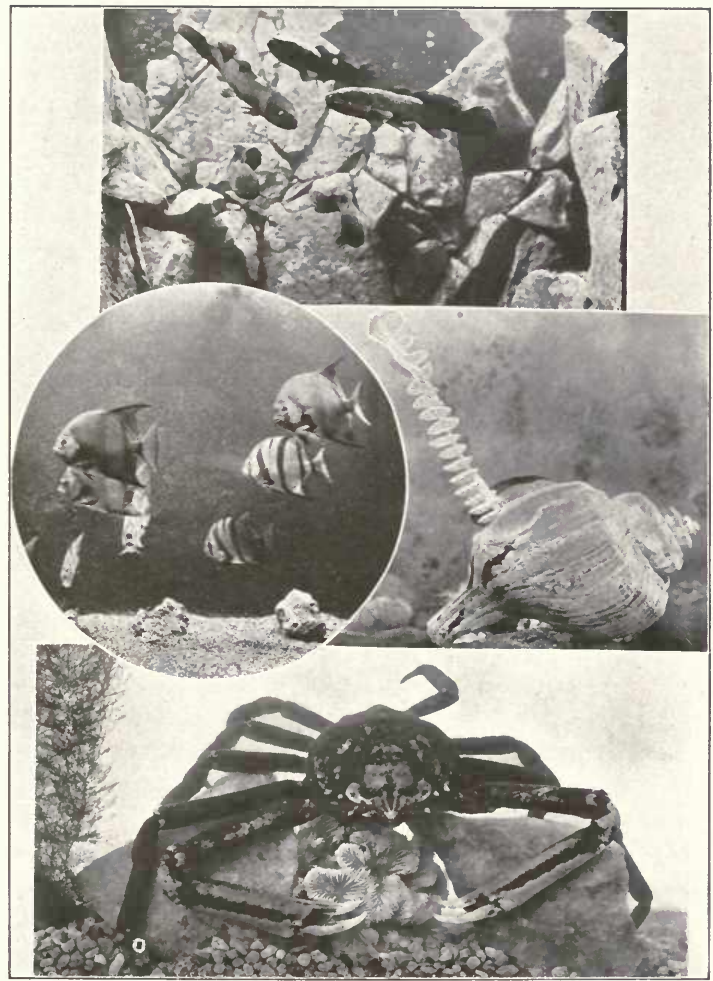

SPADEFISH

MUDFISH

SPIDER CRAB

FULGUR WITH EGG CASE 


\section{THE NEW YORK AQUARIUM}

In small tanks arranged around the edge of this pool are various crustaceans and frogs, among them the green crab, spider crab, horseshoe crab, rock crab, leopard frog, oyster and lobster.

3. Large tropical fresh-water fishes. These include the giant grouper, the drumfish, noted for feeding upon oysters, and the dog-snapper.

4. California sea lion. A species of eared seals related to the fur seals but without a commercially valuable skin. They are harmless, tractable and intelligent animals. Formerly numerous on the North Pacific Coast, they are rapidly being reduced in numbers by sportsmen and fishermen.

5. Crocodiles and alligators.

6. Sea cow or manatee. Upper Amazon River. A warmblooded, milk-giving, plant-eating mammal.

The large case to the right of the main entrance contains an exhibit of land crabs from Turk's Island in the Bahamas.

The large wall tanks on the main floor are arranged in two series, those occupying the western side of the building being devoted for the most part to fresh-water, northern fishes, and those on the eastern side to marine, tropical or subtropical forms. The exhibits do not remain constant, but vary from time to time according to demands on space and other conditions.

The tanks are all lighted from above and provided with illuminated glass labels, stating the name, habitat, greatest weight, status as food, value for sport and other interesting 


\section{THE NEW YORK AQUARIUM}

or important facts about each species. The labels also inform the observer which species are suited to small aquaria, for stocking small ponds or streams or for destroying mosquito larvæ. The rock backgrounds provided for the tanks aid in displaying the fishes to the best advantage.

The fresh-water species - for the most part North American or introduced and acclimatized in this country-include the rudd or pearl roach, an introduced fish now common in New York State waters, and the yellow roach, its native relative; the goldfish, of which several varieties are shown; the short-nosed gar, lake sturgeon, bony gar and mudfish, belonging to the group of fishes known as ganoids, of which very few species survive to-day, though, to judge from fossils, they appear to have been abundant in past ages, and such well-known game fishes as the large- and smallmouthed black bass, muskallunge, pike and landlocked salmon and various species of trout. The crayfish, a freshwater crustacean, also occupies a tank in this series.

A large tank, containing certain marine crabs and fishes, including the horseshoe king crab, common on the Atlantic coast but having no near relative except on the northeast coast of Asia, the blue or edible crab, sturgeon, flounder, spider crab, striped bass, codfish and whitefish, is also found on this side of the main hall.

The marine fishes include the following important food fishes: sheepshead, red grouper, red snapper, Nassau grouper and jewfish, one of the largest of the sea bass, reaching gigantic size. The curious snake-like morays, 


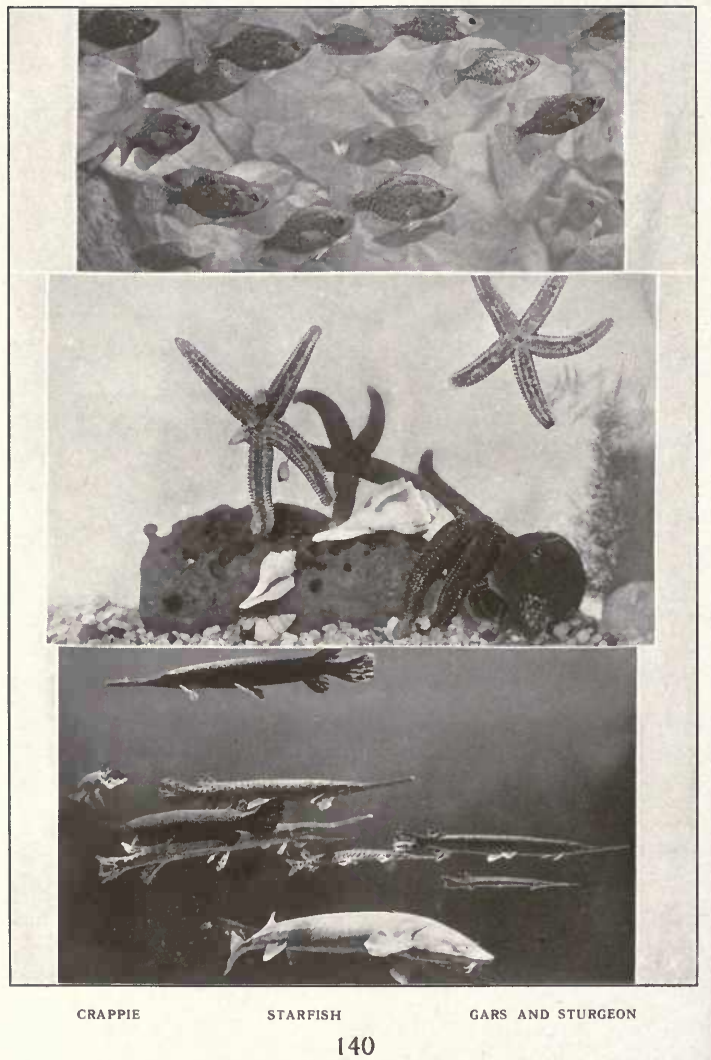




\section{THE NEW YORK AQUARIUM}

common in the tropics and in reality degenerate eels, are especially interesting and have lived many years in the Aquarium.

The angel-fish, rainbow-fish, bluefishes and squirrel-fish have been brought from tropical regions, and their brilliant colors are characteristic of species found in such environments.

A large tank, inhabited by the hawksbill turtle, a large marine turtle which provides the valuable tortoise-shell of commerce, also occupies a position on this side of the hall.

A lens cabinet, for viewing very small aquatic animals through a magnifying glass, is placed near the northeast wall; here are mosquito larvæ, tiny crustaceans, hydroids and jelly-fishes.

\section{GALLERY}

In the gallery a similar arrangement groups the freshwater forms on the west and the marine tropical fishes on the east side of the building. Many of the tanks contain young fry of the species represented on the floor below, particularly trout, salmon and other food fishes.

Fine specimens of three interesting salamanders, the hellbender or water dog of the Ohio Valley, the giant salamander of Japan, China and Tibet and the mud puppy of the Great Lakes and the Mississippi Valley, are included in the fresh-water series. 


\section{THE NEW YORK AQUARIUM}

The hellbender, the largest American salamander, has well developed lungs and, although a water dweller, comes to the surface to breathe, swallowing air through the mouth and passing it back into the lungs. It has, however, a gill opening on each side of the throat.

The giant salamander differs from its American relative, the hellbender, in having no gill openings. It lives in small streams of mountain meadows and is used as food by the Japanese.

The mud puppy breathes with gills like a fish and rarely rises to the surface. It has short but well developed limbs and is a nocturnal animal, hiding in rock crevices or weed masses in the daytime and swimming or creeping about at night to feed on crustacea, fishes, worms and frogs.

Other fresh-water fishes on this floor are the small ladder fish, a rare little fish from the interior rivers of South America, common catfish, chub, sucker, red horse, Mississippi catfish and spotted catfish, sunfish, fresh-water killie, white perch and the burbot, a fresh-water representative of the cod family.

A tank of very interesting little sea horses, the only fish with a prehensile tail, is also exhibited on this floor. The sea horses are difficult to keep in captivity because they feed only on the minute crustaceans infesting the eel grass in which they live. The male of this species hatches the eggs and cares for the young in an abdominal pouch. Enclosed in a skeleton of horny segments that permits little lateral flexion, and having only one dorsal fin, the sea horse 


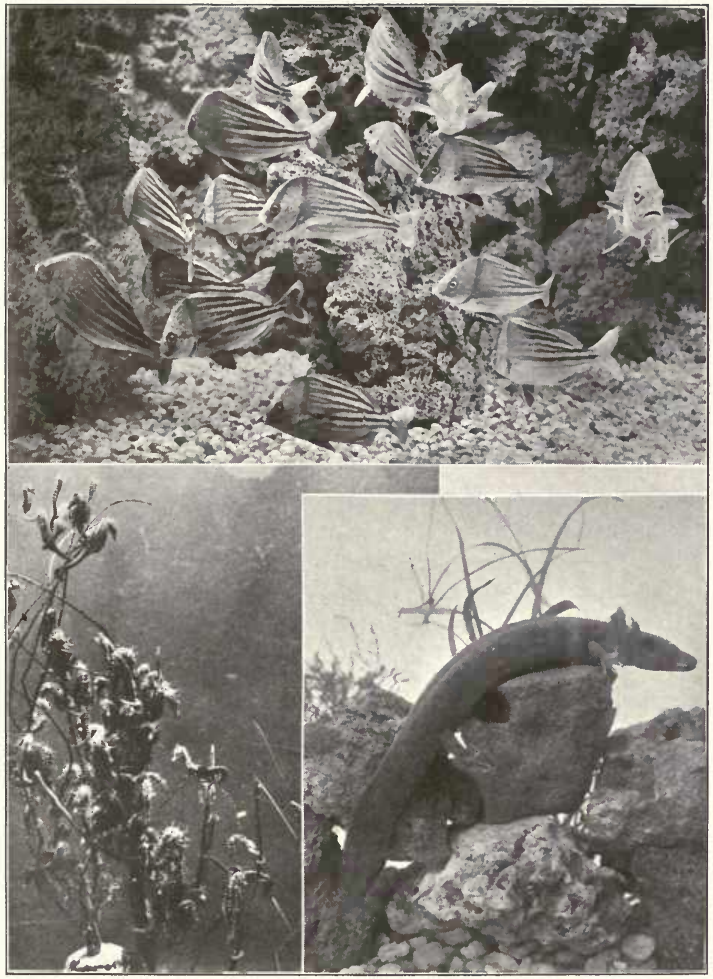




\section{THE NEW YORK AQUARIUM}

is a poor swimmer and cannot resist currents, remaining for the most part stationary, attached by its tail to grasses or seaweeds. Its comparatively large air bladder is an important factor in its equilibrium. If this is pricked to let out a bubble of gas the size of a small pinhead, the fish falls to the bottom, where it must remain until the wound is healed and a new supply of gas secreted to enable it to rise. There are about thirty-six species, mostly tropical, but one extends north to Cape Cod, and this queer little fish was exceedingly abundant in local waters last summer (1916).

Part of the wall space in the gallery is utilized for exhibiting color prints prepared by the United States Fish Commission, representing American food and game fishes and fishes of the Hawaiian Islands and the West Indies.

The small tanks in the center of the gallery contain the Mexican swordtail, the Indian gourami and other fishes. It is interesting to see the gouramis utilize their filamentous fins as organs of touch.

During the appropriate seasons there is maintained at the Aquarium, as a fish-cultural exhibit, a hatchery in which millions of young food and game fishes are produced for the enrichment of the fishing waters of New York State, the fish eggs for this purpose being supplied by the United States Bureau of Fisheries. 


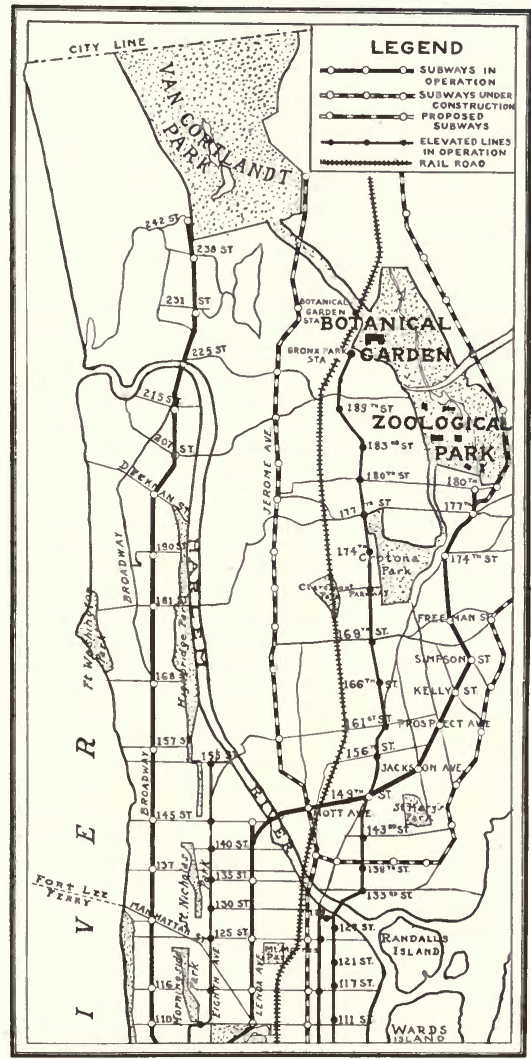




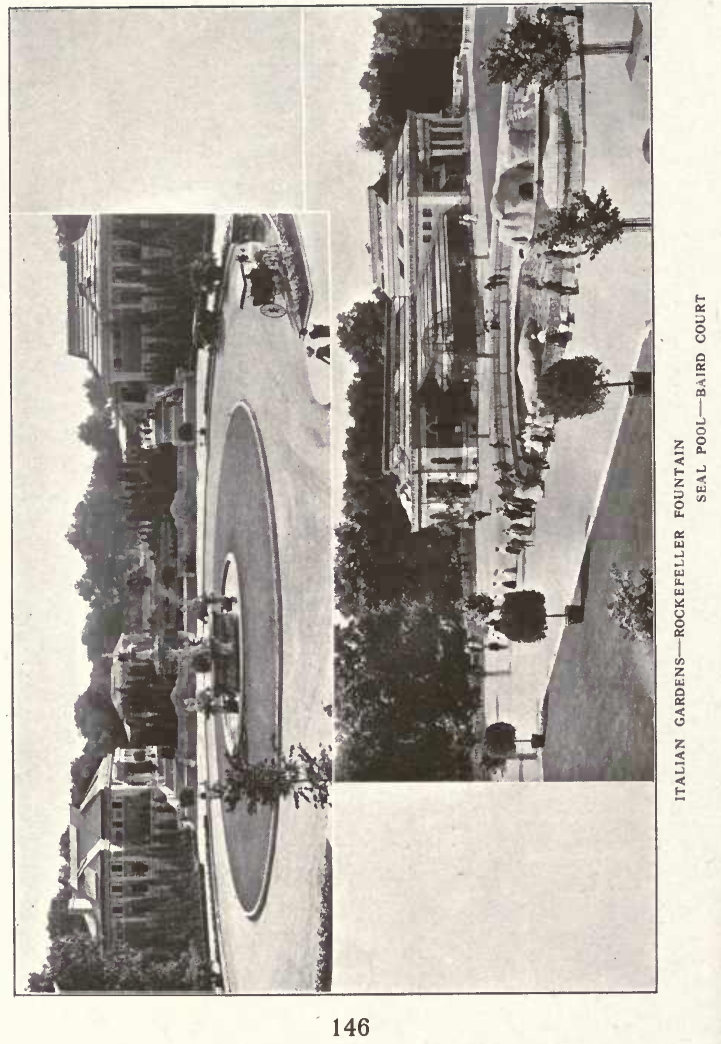




\section{THE NEW YORK ZOÖLOGICAL PARK}

The New York Zoölogical Park was conceived and planned by the New York Zoölogical Society, a scientific body incorporated in 1895, under a special charter granted by the Legislature of the State of New York, and has as its avowed objects the making of a public zoölogical park, the protection of American native animals and the promotion of zoölogy.

Control of the Park grounds was granted to this Society by the City of New York in 1898 and work on the permanent buildings was at once begun. The comparative newness of the Park has enabled its founders to profit by the world's experience in the planning of quarters for captive animals, and many original features have been devised either to meet special conditions or to improve upon existing methods. The Park occupies 264 acres of land and water, whose varied contour comprises rocky ridges, sheltered valleys, lakes, deep forest and open glades, making it possible to provide for the animals a suitable habitat and affording space to an extent unrivaled by any other institution of its kind.

The planning and general development of the Park are 


\section{THE NEW YORK ZOÖLOGICAL PARK}

in the hands of the Zoölogical Society, which has also furnished all the live animals and erected the Reptile House, Aquatic Bird House, Bear Dens, Flying Cage and other structures.

The City of New York has erected the majority of the buildings, provided funds for the construction of walks, roads, sewers, drainage, water supply and other improvements, and also has furnished an annual maintenance fund for general upkeep.

The Society's funds are obtained by private subscription and from the dues and fees of its members; and, by arrangement with the City of New York, the Restaurant and other revenue-producing institutions within the Park are controlled by the Zoölogical Society and the profits expended for the increase of the animal collections.

Membership in the Zoölogical Society is open to all interested in the objects of the organization, at a cost of $\$ 10$ per year for annual membership, which entitles the holder to admission to the Park on pay days, to receive the annual reports, bi-monthly bulletin and the scientific publication "Zoölogica," to enter the Administration Building, to attend all lectures and special exhibits and to receive complimentary tickets for distribution. Any Annual Member may become a Life Member on payment of $\$ 200$. A subscriber of $\$ 1,000$ becomes a Patron, of $\$ 2,500$ an Associate Founder, of $\$ 5,000$ a Founder, of $\$ 10,000$ a Founder in Perpetuity, and of $\$ 25,000$ a Benefactor.

The Zoölogical Park is located between East 180th and 


\section{THE NEW YORK ZOÖLOGICAL PARK}

190th Streets, and may be reached by the subway to 180 th Street (care must be taken to select a Bronx Park or West Farms train, which brings visitors to the southeast or Boston Road entrance of the Park); by the Third Avenue Elevated Railway to Fordham station, which is half a mile from the northwest entrance, or by the Southern Boulevard or Zoölogical Park surface cars. Carriages and automobiles are not permitted to enter the portion of the Park occupied by the animals. They may enter the Park at the Concourse on Pelham Avenue, whence they may proceed to the northern end of Baird Court, where is situated the most important group of buildings.

The Park is open free every day of the week except Mondays and Thursdays. On these days, except when they fall upon holidays, an admission fee of twenty-five cents is charged for each adult and fifteen cents for each child, except to members of the Society or to those holding tickets therefrom.

From May 1 to October 31 the gates are opened at 9 A.M. daily, and closed half an hour before sunset. From November 1 to April 30 the gates are opened at 10 A.M.

The Boston Road, running through the Park from north to south, divides it into two portions. That on the west contains the animal collections; that on the east contains Bronx Lake, twenty-five acres in extent, which may be utilized by visitors for boating. Boats may be obtained at the Boathouse at the southeast end.

The size of the Park, the existence of six entrances and 


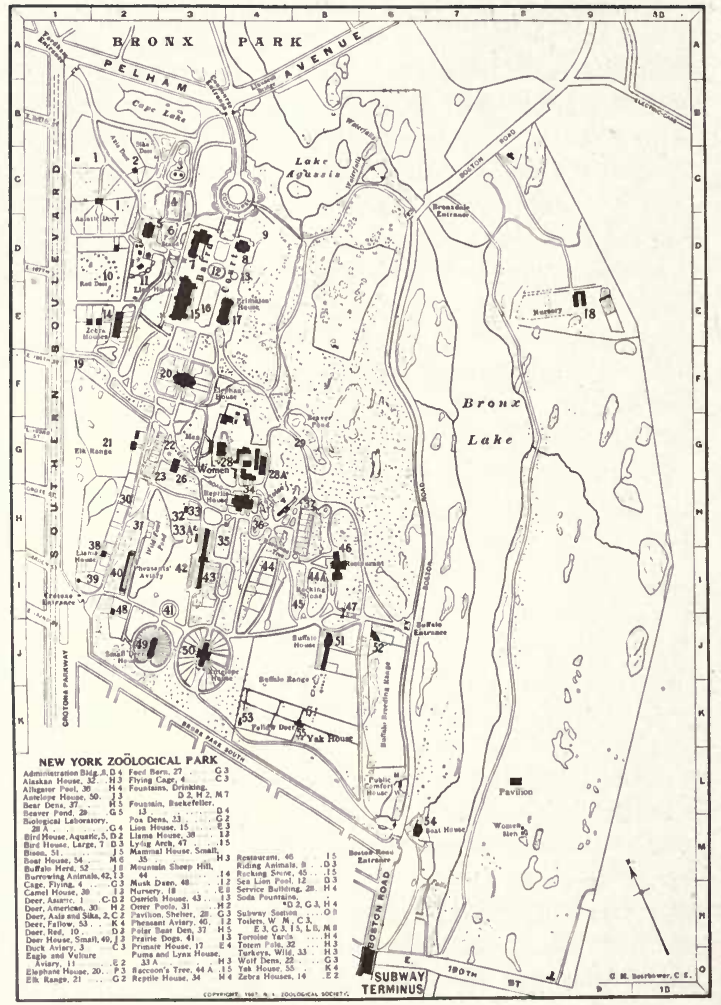




\section{THE NEW YORK ZOÖLOGICAL PARK}

the fact that the physical features of the Park have determined the location of the various animals make it impossible to plan a tour for the visitor which will embrace everything without retraversing some of the paths. The visitor with limited time at his disposal, or who wishes to see only particular specimens, should consult the map and key on page 150 , by means of which the various installations may be readily located.

Of large and elaborately equipped buildings of brick and stone there are the following:

Elephant House

Lion House

Primate House

Large Bird House

Aquatic Bird House

Pheasant Aviary
Reptile House

Small Mammal House

Ostrich House

Antelope House

Small Deer House

Zebra House

All these buildings are provided with open-air yards in which the inhabitants can exercise and be observed.

Of less important animal buildings there are the following:

Asiatic Deer House

North American Deer House

Axis Deer House

Elk House

Musk-ox House

Camel House
Llama House

White Goat Barn

Buffalo Barn

Wild Horse House

Yak House

Eagle Aviary 


\section{THE NEW YORK ZOÖLOGICAL PARK}

All the hoofed animal houses are connected with extensive outdoor ranges where the herds may be observed at large.

Of open-air installations for wild animals and birds there are the following:

Bear Dens

Flying Bird Cage

Wolf and Fox Dens

Mountain Sheep Hill

Sea Lion Pool

Penguin Pool

Wild Fowl Pond

Otter House

Beaver Pond
Burrowing Rodents'

Quarters

Prairie Dog Village

Puma and Lynx House

Raccoon Tree

Pigeon House

Goose Aviary

Wild Turkey Enclosure

Turtle Pond

\section{Crane Paddock}

At the Rocking Stone Restaurant, dining and lunch rooms are provided. Wheel chairs may be obtained at entrance or from Chief Clerk in the Central Service Building.

From the Boston Road entrance, the path to the right passes first the Yak Range, where a herd of this wild ox of Tibet affords an interesting comparison with the American bison, or buffalo, occupying an extensive range and corral just beyond. From the roof of the Buffalo House a fine outlook is obtained over the ranges. Of the countless thousands of wild bison once occupying undisturbed the whole pasture region of the western United States, there remain only about twenty individuals now in the 


\section{THE NEW YORK ZOÖLOGICAL PARK}

Yellowstone Park, somewhat more than 300 in the barren territory southwest of Great Slave Lake, Canada, and a few small captive herds elsewhere numbering about 2,000 individuals. The western herds were largely reëstablished from stock furnished from the New York Zoölogical Park.

The path to the left, skirting the Buffalo Range, brings the visitor to Mountain Sheep Hill (44 on map), where a steep rocky ridge affords a fine natural habitat for the wild sheep and goats. The Himalayan tahr, the wild goat of northern India, has bred very successfully in the Park; the original pair have a large and active family and even climb the trees in their enclosure. The aoudad, or Barbary wild sheep, the Spanish and Persian ibexes, the mouflon of Sardinia and the burrhel of India are found here, but the Rocky Mountain goat and the bighorn or Rocky Mountain sheep do not thrive in these enclosures and will be found elsewhere.

At the northern end of Mountain Sheep Hill, the visitor faces the Bear Dens, where, in large open yards, with sleeping dens in the rocks behind, the various species of bear are comfortably accommodated. Up the steps to the left is the Rocking Stone Restaurant (46 on map), and the Raccoon Tree, where a number of lively raccoons are acclimatized, is in sight south of the Bear Dens.

A small pond for native wild turtles lies between Mountain Sheep Hill and the Restaurant, where several species may usually be seen basking on the half-submerged log at one end. 


\section{THE NEW YORK ZOÖLOGICAL PARK}

The Park's bear collection is a large one, including, in the main cages, the American black bear, the grizzly bear, the Syrian bear, the hairy-eared bear, the great Yezzo bear of Japan, several species of Alaskan brown bear and the Kadiak bear. Two fine polar bears are in a large den down the steps north of the main bear dens, and still other species are found facing the main dens on the northwest. The northern compartments of these smaller bear dens accommodate also the laughing hyena and the South African hyena dog. The path beside these latter dens affords a fine view of the Beaver Pond and Dam and brings the visitor to the back of the Reptile House.

The open-air Tortoise Yards flanking the east wall of this building may be examined first; here, in summer, the tortoise and large tropical lizards may be seen taking air and exercise. These yards are connected with indoor quarters for use when the weather is cool. The giant tortoises are especially interesting, growing to enormous size and living to a great age. The largest specimen, from the Galapagos Islands, weighs 225 pounds. These creatures are now to be found only on isolated groups of islands in the Pacific and Indian Oceans, but from fossil remains found elsewhere they appear once to have inhabited all the continents. Among large lizards, the Australian monitor, the powerful tegu of South America and the iguanas should be mentioned. The lizards here and in the Reptile House form a comprehensive collection.

The Reptile House, the first large building to be erected 


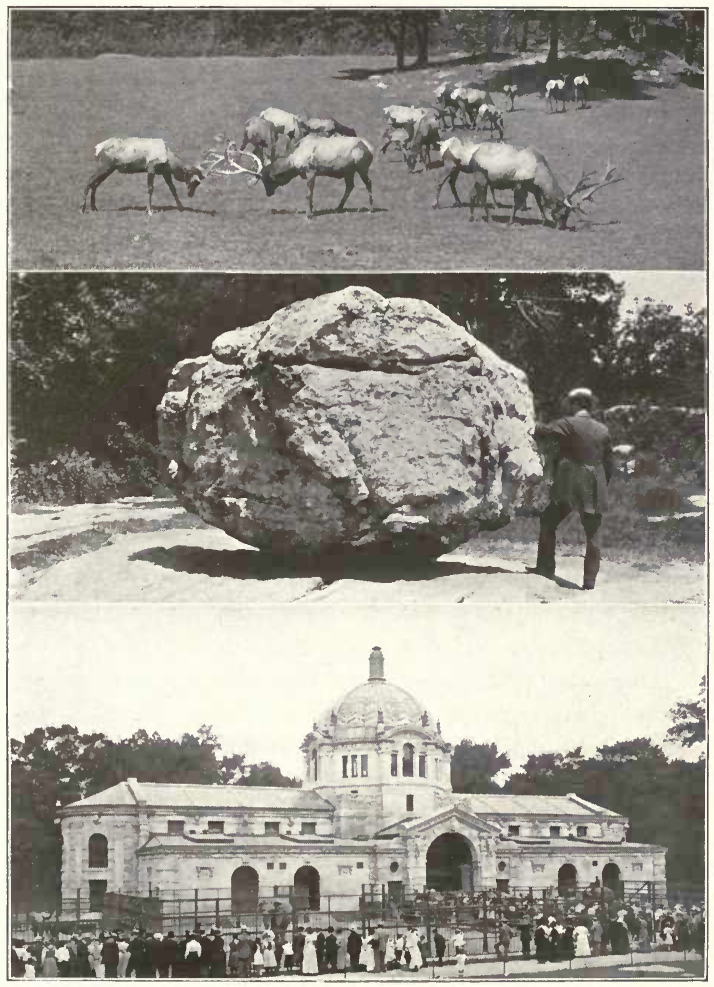

ELK HERD

ELEPHANT HOUSE

ROCKING STONE 


\section{THE NEW YORK ZOÖLOGICAL PARK}

in the Park, contains a series of examples, carefully selected, to afford a general view of the four important groups of living reptiles-turtles, crocodiles, lizards and snakes-and of the still more interesting amphibiansfrogs, toads, newts and salamanders. Even in this large building it is impossible to show anything approaching a complete collection of the reptiles of the world, and the arrangement of exhibits varies from time to time according to conditions and demands on space.

To the right of the south or entrance hall there is shown, for purposes of local interest and instruction, a collection of the harmless and poisonous snakes of New York State. The window cases at the left of this hall house a series of American batrachians, including various frogs and toads, among them the huge bullfrog; the curious glass snake (really a lizard but having no external legs), the hellbender, salamander and others.

At the western end of the great central hall of the Reptile House is the Crocodile Pool with its sloping banks, for which the conservatory of tropical vegetation behind affords a natural setting and a homelike outlook for the inmates. A number of American alligators, from two or three to twelve feet long, inhabit the pool the year round.

One division of the Crocodile Pool is occupied by the gavial, a rare crocodile from the Ganges River.

Young alligators are kept in four groups, according to size, in various parts of the Reptile House.

The central space of the main hall is devoted to the tur- 


\section{THE NEW YORK ZOÖLOGICAL PARK}

tles. A large tank at the eastern end accommodates the larger specimens and is also a nursery for many young crocodiles and alligators. A stream of water thirty-five feet long, with banks of earth and living plants, is divided into sections for the smaller species of turtles, of which thirty or more types are exhibited. The strange aquatic, soft-shelled turtle is in a case at the right of the entrance.

The batrachians or amphibians (frogs, toads, newts and salamanders), Nature's half-way house between land and water animals, are shown in a series of cases flanking the western and eastern ends of the Turtle Pool. A few may be found on the south side of the building. This collection is one of the best in existence, containing nearly one hundred different species from all over the world, some of them very rare. Certain of these exhibit very interesting adaptations, as the axolotl, a Mexican salamander which lives in water as long as the water lasts but if this dries up begins to breathe with its lungs and to walk about on the land. The rare tree toads of Australia and African swimming frogs are found here.

Serpents or snakes (with some lizards) are ranged around the northern and eastern sides of this hall. Of these, the huge tropical boas and pythons of India and Africa and the anaconda and boa constrictor of South America are among the most showy of a large and interesting series. The largest specimen is the regal python of Africa, twenty-two feet long and weighing 170 pounds. Other specimens are the Indian python, the garter snake, 


\section{THE NEW YORK ZOÖLOGICAL PARK}

blue-tailed lizard, horned toad (a desert lizard), tree boa, pilot snake, carpet snake and others. The exhibit of venomous snakes is especially comprehensive and contains among others the diamond-backed rattlesnake of Texas, the cobra-de-capello of India, responsible for the loss of about 18,000 lives annually, and the deadly fer-de-lance and bushmaster of South America.

Bordering on the north side of the Turtle Pond is a fine collection of snakes of the southern United States, and a case on the southeast side of the hall exhibits skulls and fangs of harmless and poisonous snakes, indicating the difference between them. Many interesting snakes and batrachians find a place also on this wall. The southwest wall is devoted to the Economic Rodent-Reptile Collection, showing the rodents most destructive to agricultural interests and the snakes which prey upon them. This extensive and valuable series contains about fifty species of rodents, some of them rare and interesting, such as the Egyptian desert mouse, the Indian jerboa, the Egyptian jerboa (a kangaroo-like rat), porcupine mouse, European marmot and the flying squirrel; and, inasmuch as some of those exhibited are nocturnal in habit, it is an achievement to have induced them to show themselves in daylight.

The Reptile House formerly contained a considerable collection of insects. It has been found impracticable to keep this up for lack of space, but various interesting tarantulas, centipedes and other types are still to be found here, among them the curious bird-killing spider. 


\section{THE NEW YORK ZOÖLOGICAL PARK}

A small elevation southeast of the Reptile House is the location of the so-called Alligator Pool, now given over to sea lions and penguins. The active and noisy California sea lions are always showing off here (as well as in their larger pool in Baird Court). They belong to the same family as the fur seals, but are of a different species.

The penguins exhibited are the small blackfooted penguins from the Cape of Good Hope.

Just southeast of the Reptile House is the Small Mammal House, on the way to which the Wild Turkey Enclosure is observed on the right, where the king of American game birds occupies a quarter of an acre of wood and undergrowth.

The open-air Puma and Lynx House immediately adjoins the Turkey Enclosure, and here the American puma or mountain lion paces restlessly to and fro. This animal, like the lynx, does not thrive in heated buildings. It is found in Florida, Texas and most of the western states, as well as in Central and South America, but it is by no means as dangerous to man as rumor relates.

Next door to the puma are two fine adult specimens of the Canadian lynx.

The Small Mammal House, although not the most showy, is from an educational standpoint one of the most interesting installations in the Park, containing species representing many different orders of mammals. The carnivorous mammals are extensively represented by members of the cat and dog families, including the rare and beautiful 


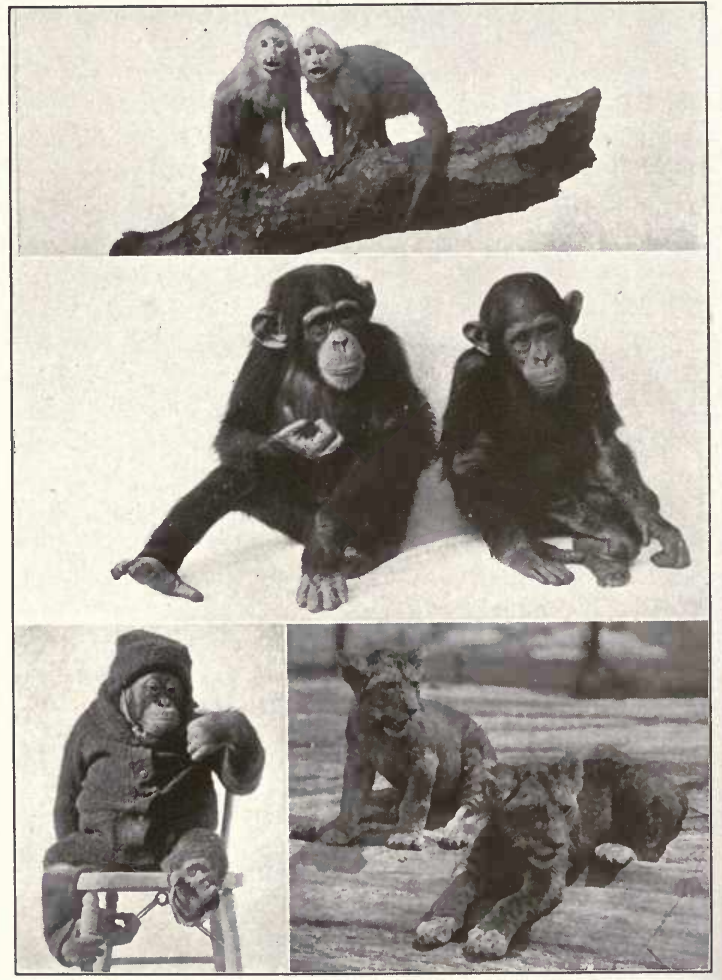

WHITE-THROATED SAPAJOU MONKEYS

CHIMPANZEES 


\section{THE NEW YORK ZOÖLOGICAL PARK}

ocelot, the African serval, the civet-cat, jackals, raccoons and various wild dogs and foxes. Interesting rodents are the South American capybara, largest of all living rodents, and the brilliant Malabar squirrel. Among the mammals are the Australian wombat and the opossum; and the edentates, or toothless mammals, make a good showing with the giant anteater, the curious banded armadillos and the sloths; perhaps the most interesting creature, the Echidna, or spiny anteater, belongs to the remarkable order of egglaying mammals. This house contains about 200 cages, of varied type and size according to the occupant, but all with open-air yards attached.

Porcupines, badgers, the South American agouti and coati-mundi, tropical squirrels and rodents, and the young of many species such as bears and leopards, which require small quarters and special care, are to be found in this building, a good time to visit which is 1 P.M., when its inhabitants are fed. Each label bears a color band, a different color for each order of mammals, and a large keylabel at each end of the hall makes classification into orders easy.

Connected by a central pavilion with the Small Mammal House is the Ostrich House, devoted for the most part to the large running birds, such as the ostriches, rheas, emus and cassowaries. The emus, however, now occupy a range and house adjoining the yaks, near which in the summer time the North African ostrich and certain of the cranes have ranges and quarters. 


\section{THE NEW YORK ZOÖLOGICAL PARK}

The South African ostrich, the great-billed rhea of Brazil, the Javan peacock, the African bustard, the curassows, cranes, the curious cassowaries, the well known snake-killing secretary bird, and other interesting species occupy the Ostrich House and its adjoining yards.

Flanking the west side of the Ostrich House are the quarters of the Burrowing Mammals (42 on map). This large and important group of animals comprises the squirrel, rabbit, rat, mouse, opossum and gopher families, the curious sewellel family and others; some of these are kept in the Small Mammal House. In summer certain families not properly belonging here, such as the raccoon dogs, swift foxes and others, occupy some of the yards. In winter all the burrowing mammals are transferred to the Small Mammal House.

Leaving these quarters, the path proceeds south to the Antelope House (50 on map), where a finely equipped central building, heated in winter and provided all around with open-air corrals, accommodates the giraffes, a large and remarkable series of African antelopes and several Indian species.

Among these, the three-horned Nubian giraffes, the curious African gnus, the rare Beatrix antelope from Arabia and the Indian nilgai are especially interesting. The dromedary, or single-humped camel, also finds a home in this building.

West of the Antelope House, a short path connects directly with the Small Deer House (49 on map), where an- 


\section{THE NEW YORK ZOÖLOGICAL PARK}

other carefully designed building with outdoor corrals takes care of the more delicate species of deer unfitted for open ranges, the smaller African antelopes, the various tropical swine, the kangaroos and in winter the tropical mountain sheep and goats.

Many interesting species from India are here represented, including the muntjac deer, the sasin antelope, the four-horned antelope and the dainty Indian gazelle. From Mexico and South America, the black-faced brocket and the Sinaloa white-tailed deer are of particular interest because of their unusually simple horns.

Near the northern entrance to the Small Deer House is the Prairie Dog Village (41 on map), where about one hundred fat little prairie marmots from Montana dodge in and out of their burrows, indulge in joyful squeals and prove generally entertaining.

Leaving these on the right and proceeding westward, the next enclosure is that of the white-fronted musk-ox (48 on map). This strange-looking animal from the arctic regions belongs to neither the cattle nor the sheep family but stands in a genus of its own midway between. The Park has a herd of six specimens.

A barn and corral, adjoining the musk-ox, houses the Rocky Mountain goat. This animal, accustomed to great heights and a rarefied atmosphere, is difficult to keep in captivity, but has been successfully established here on a breeding basis. Enclosures to the west and south contain groups of Virginia deer. 


\section{THE NEW YORK ZOÖLOGICAL PARK}

At the right of the path by the Musk-ox Enclosure, the visitor will observe a large pond extending northward. This is the Wild Fowl Pond, where the ducks and geese breed in the grass and underbrush on the east bank and bring their broods to the water when hatched. Here, besides the mallard, pintail, gadwall, rosy-billed duck, black duck, lesser scaup duck and other ducks of America, may be seen the paradise sheldrake of Australia, the ruddy sheldrake of the Mediterranean, the Chinese mandarin duck and others. The geese include the snow goose, Cereopsis goose and barnacle goose.

An old fable, still believed by many European peasants, especially in Ireland, is that the barnacle or bernicle goose is born from the stalked barnacles that adhere to driftwood on the sea coast, and circumstantial accounts have been given of the young developing in and escaping from the barnacle shells. The name "bernicle," like brant, refers to the burnt or black color of the birds, but the barnacles were really named after the bird, not the bird after the crustacean.

The Pheasant Aviary (40 on map) faces the Wild Fowl Pond at its southern end. In this building and its runways is housed one of the finest collections of true pheasants in the world.

Each species has for use at all times an open yard, a storm shelter and a closed room with a large window, and owing to the shy and retiring habits of some of the birds it may be necessary to visit the aviary more than once in 


\section{THE NEW YORK ZOÖLOGICAL PARK}

order to see them all. Some of the most beautiful birds in the collection are the golden and silver pheasants of China, now acclimatized successfully in British Columbia and in Oregon, the Amherst pheasant, the beautiful Soemmering or copper pheasant of Japan, the Impeyan pheasant of India and the exceedingly rare Mongolian pheasant of Turkestan. Above each of the pheasant enclosures a roomy dovecote provides for a collection of pigeons, without interfering with the pheasant runs below.

The steps at the left of this aviary lead to the Camel House (39 on map), where the two-humped or Bactrian camel may be ridden by visitors in the winter time. In summer he sheds his coat and is not in his best form.

The Llama House adjoins the Camel House on the north and exhibits the llama, alpaca, guanaco and vicuña of South America, animals related to the camel family, but smaller and without a hump, and valued largely for their wool.

Behind the Llama House, in an extensive range containing a small lake, is a beautiful herd of the white-tailed Virginia deer.

To the right of the Llama House one may overlook the Wild Fowl Pond and descend to investigate the cages of the otter and of the odd coypu rat of Central and South America, which abut on the Pond near the center of its western bank. The totem pole and house of the Tlingit Indians of Cape Fox, Alaska, presented to the Park by the late Mr. E. H. Harriman, are also in sight from this point.

The Indian hangul deer and Florida white-tailed deer 


\section{THE NEW YORK ZOÖLOGICAL PARK}

adjoin the llamas on the north, followed by the Elk House and corrals, in a range behind which (21 on map) appears a fine herd of American elk, or wapiti, except the moose the largest member of the deer family and of all American deer the most easily reared in captivity.

To the right of the Elk Range, down a short hill, are the Dens of the Wolves and Foxes, occupying the slope of a natural ridge or rock. Here are the gray wolf, the coyote, the rare Tasmanian wolf, the red fox, and the dingo or wild dog, but several of the foxes have been found to thrive better in the Burrowing Animals' Quarters.

Directly north from the Wolf Dens is the Elephant House, the largest animal building in the Park. This imposing structure, with a dome in the center and ornamented with animal sculptures by the well-known sculptors A. Phimister Proctor and Charles R. Knight, is 170 feet long and 84 feet wide, and is divided lengthwise into eight huge compartments, four for elephants, two for rhinoceroses and two for hippopotami. At each end of the building are smaller cages for tapirs and young elephants. Each interior cage is connected with a large open-air corral where the animals can exercise.

A full-grown Indian elephant and two young African elephants are to be seen, as well as the rare and curious Indian rhinoceros, the African two-horned rhinoceros, the African hippopotamus and the pygmy hippopotamus; the latter, also from Africa, has never before been found in captivity. The hippopotami have a large bathing tank within the 


\section{THE NEW YORK ZOÖLOGICAL PARK}

building to serve instead of the river they frequent when at home.

North of the Elephant House is Baird Court, where are situated the Lion House, the Primate House, the Large Bird House and the Administration Building, the latter not open to the public.

The Lion House (15 on map) is a spacious building, decorated exteriorly with animal sculptures by Eli Harvey, with large raised outdoor cages and sleeping dens for the animals, communicating as usual with indoor accommodations. Here Barbary lions, Bengal tigers, leopards, jaguars, Siberian tiger, pumas and other large felines make a splendid spectacle. These animals are fed at 2 P.M. A studio, at the northeast end of the Lion House, is arranged for the use of artists who wish to make life-studies of its animals.

In the Primate House (17 on map) are the animals nearest to man in the zoölogical order: the anthropoid apes, baboons, monkeys and lemurs.

The north hall of this house contains the anthropoid apes, the type nearest to man; of these, the chimpanzee and orang-utan are always kept on exhibition, and in their large outdoor cage are a constant source of entertainment. The great apes, however, are short-lived in captivity, and therefore somewhat uncertain quantities in zoölogical parks. The gorilla is especially delicate, and this most human-like of the apes cannot always be shown for the reason that specimens are difficult to obtain and quickly 


\section{THE NEW YORK ZOÖLOGICAL PARK}

die of indigestion and lack of exercise. The white-handed gibbon, farthest from man of the anthropoids, has a large cage on the west of this hall and spends much time swinging on the long bar provided for him in place of his native tree-tops.

The baboons are strong fierce animals accustomed to life upon the ground surrounded by enemies, and have to be treated with respect. Of these the mandrill of West Africa is the most extraordinary and the golden baboon the best tempered in captivity. The long-armed baboon, the chacma baboon, the hamadryads of Arabia and others are also exhibited, on the east of the central hall. These cages are all provided with outdoor accommodations. Of the Old World monkeys, the rhesus monkey of India, one of the sacred species, the mona monkey and sooty mangabey of Africa, the Japanese red-faced monkey and the entellus monkey of India are to be found among other representative types.

Except for the sapajous (the hand-organ monkeys), which are interesting for their prehensile tails, the New World monkeys are not very hardy, the spider monkeys, sakis and yarkes being especially delicate. The rare Humboldt's woolly monkey has not been successfully kept inside in small cages on account of its delicacy.

The lemurs, monkey-like animals, chiefly from India or Madagascar, are found east of the south hall. They belong to the lowest group of the Primates and are nocturnal in nature, but in the Primate House they appear to like the sunshine. 


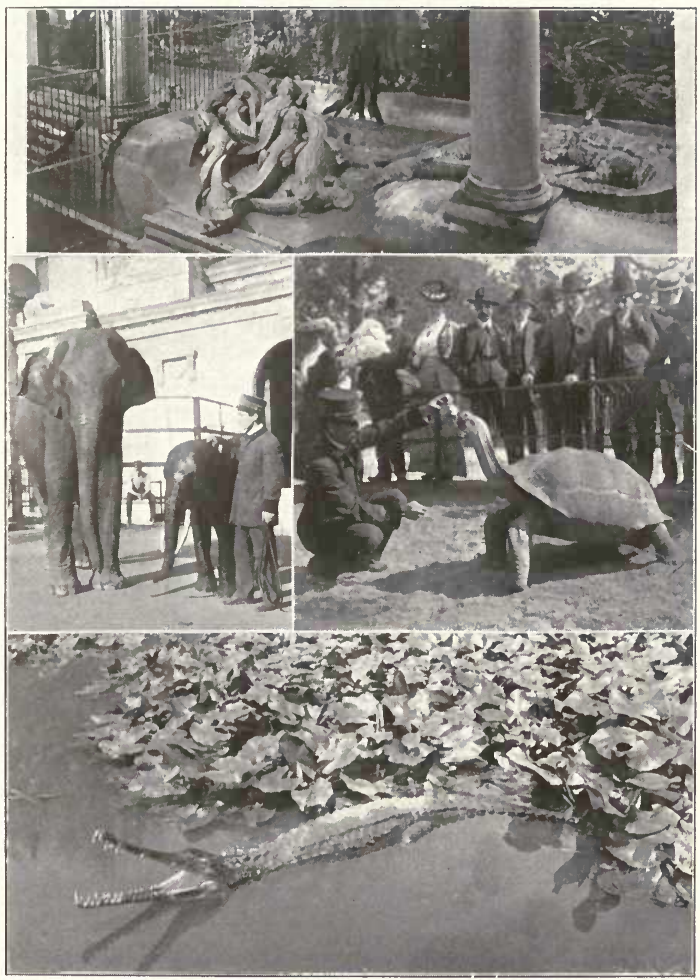

ALLIGATOR POOL 


\section{THE NEW YORK ZOÖLOGICAL PARK}

In the center of Baird Court is the large Sea Lion Pool, where the animals are often seen engaged in spectacular diving. At the north end of the Court, the Concourse and Italian Gardens lead to the Concourse entrance and the Botanical Garden.

The Administration Building, at the northwest corner of Baird Court, is the scientific, literary and artistic headquarters of the Zoölogical Society and contains also Meeting Rooms for its Members, a Library, Galleries and the Offices of the Director and Staff. This building is not open to the public, but the valuable and extensive collection of hoofs and horns which is housed here may be seen by scientists, sportsmen and others especially interested.

This collection, intended finally to be an impressive exhibit of the world's horn-bearing animals, already contains about 1,000 specimens, many of them of record size and all especially fine and rare. The exhibit is arranged in two series, occupying separate galleries: a zoölogical series, intended to show the evolution and relationships and arranged by families and genera, and a geographical series, designed to display the hoofed animal resources of the various continents.

The Reed-McMillin collection, donated to the society in 1907 by Emerson McMillin, is especially fine and contains besides horned animals some interesting bear and walrus heads.

A completely mounted specimen of the exceedingly rare Chinese takin presented by Mason Mitchell may also be 


\section{THE NEW YORK ZOÖLOGICAL PARK}

seen. The collection of moose, elk and American bison heads, the gift of Clarence H. Mackay, occupies the walls of the adjoining Members' Room.

Several fine animal paintings by Carl Rungius, a nucleus for the collection of animal paintings and sculptures which the Society intends eventually to possess, are hung in the galleries of the Administration Building.

The Large Bird House, at the northwest corner of Baird Court, is an L-shaped building with an all-glass house in its angle. It is specially designed for perching birds and is one of the finest collections of its kind in existence. Large cages with many birds in each cage constitute the principle of its construction-a comparatively new idea.

The main hall contains the foreign song birds, tropical doves and pigeons, birds of paradise, toucans and many other oddities. In the northeast corner of this hall are the cages containing the smaller finches and weavers, including many from Africa, India and China.

The large Flying Cage in the center of this hall contains many types, from small tropical perching birds to heavy swimmers and waders, all apparently contented in one enclosure. Among these are the Yucatan cardinal, grenadier weaver, English skylark, rain quail and the rare ringed teal of Brazil and Argentina.

The top of the L is Parrots' Hall, where the more beautiful and typical parrots, parrakeets, macaws and cockatoos may be found.

The Glass House is planned to contain the birds of the 


\section{THE NEW YORK ZOÖLOGICAL PARK}

order Passeres, or perching song birds. All the twenty-one families of eastern North American perching birds are represented: flycatchers, swallows, wrens, mockingbirds, catbirds, thrushes, kinglets, vireos, waxwings, shrikes, nuthatches, brown creepers, warblers, pipits, horned larks, sparrows, honey creepers, tanagers, blackbirds, orioles, English starling, crows and jays, as well as many foreign and tropical species.

The cages in the Glass House, flanking the passage to the Parrot Hall, contain especially rare, delicate or quarrelsome birds, which thrive better here than in the larger flight cages. Among many of uncommon interest is the lately arrived cock-of-the-rock from South America.

A collection of quail is also to be found in cages in the Glass House.

In order that the visitor may distinguish between the many birds in each cage, a picture key is provided on all the labels of all the bird exhibits.

A circular flying cage at the outer corner of the Glass Court contains the flicker, tanager, robins, thrushes, cardinal, Baltimore oriole and others hardy enough to winter out of doors.

In cages along the outside of the western hall of the Large Bird House will be found the crow and blackbird families. On the east side of Baird Court, between the Primate House and the Administration Building, an exhibit of bird houses, shelters and food holders designed for attracting and encouraging wild birds is arranged in order to 


\section{THE NEW YORK ZOÖLOGICAL PARK}

stimulate and encourage public interest in bird preservation and protection.

Leaving Baird Court by the steps southwest of the Large Bird House, the Eagle and Vulture Aviary at the left (11 on map) claims attention, containing in seven large flight cages and six smaller cages a fine collection of these birds of prey. Among them are the lammergeier vulture of Asia, the booted eagle, vulturine sea eagle, the bateleur eagle of Asia and Africa, the rare harpy eagle of South America, the kolbe, the red-tailed and other hawks, the American or bald eagle, condor and others.

A beautiful wooded park containing a herd of the European red deer surmounts the slope overlooking the Eagle Aviary, and south of these the Zebra House with its outdoor corrals (14 on map) accommodates the zebras and wild asses. The Wild Horse House and corrals adjoin these on the west.

Grévy's zebra, Grant's zebra, Chapman's zebra and the rare mountain zebra of Cape Colony are here, and the herd of Mongolian wild horses is especially interesting, providing a link between the zebras and wild asses and the unstriped domestic horse.

The Persian wild ass, the gudha, or dwarf donkey, and the Rocky Mountain sheep have their homes here.

Descending again into the bird valley, east of the European red deer, passing the outdoor cages for various pigeons and doves, the Aquatic Bird House is found, surrounded by ten large outside cages containing the owls. 


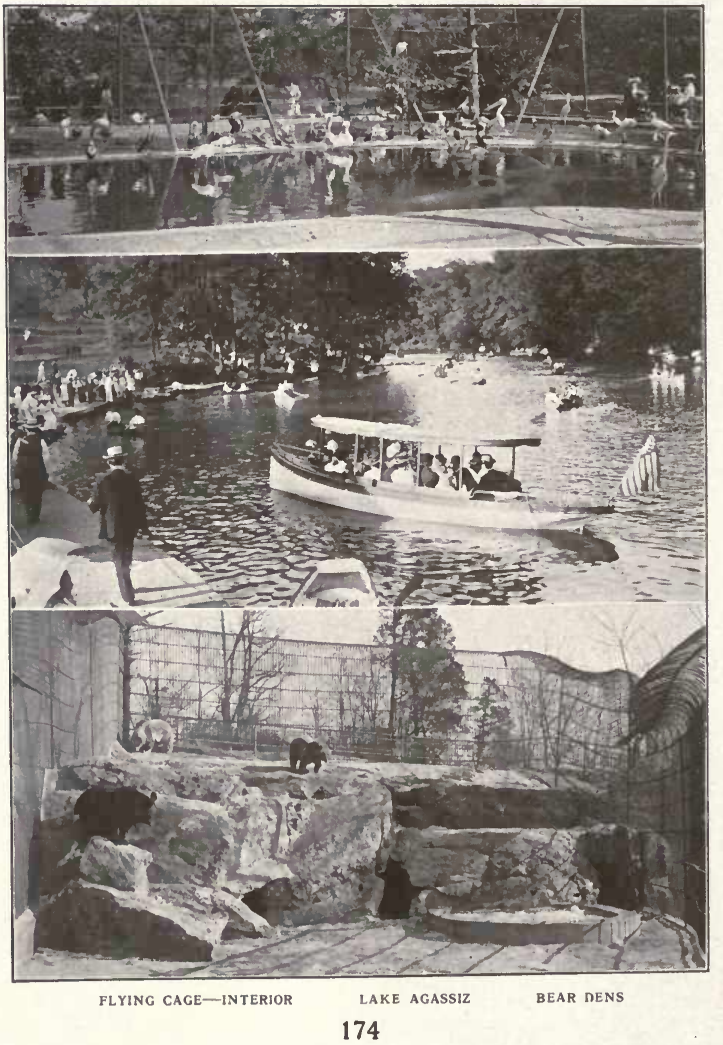




\section{THE NEW YORK ZOÖLOGICAL PARK}

The house is used in winter for the occupants of the outdoor Flying Cage; in summer the Aquatic Bird House is closed. Several large outdoor bird cages southwest of the Aquatic Bird House contain the grackles, finches, sparrows and other hardy American birds.

The Flying Cage ( 5 on map) is one of the most interesting installations in the Park: a huge structure of wire netting supported by a steel frame and enclosing several large trees and a good-sized pond. The cage is 152 feet long, 55 feet high and 75 feet wide, permitting a considerable range of flight to its occupants. These are a varied assortment of rare and showy water birds, among which are the wood ibis, the Indian, black, scarlet, black-headed, and white ibises, the roseate spoonbill, purple gallinule, snowy egret, cormorant, the Franklin and several other species of gull, the snake bird, some rare ducks, and five species of the active and amusing pelican. Feeding time for the Flying Cage is 4 P.M.

The Crane Paddock, west of the Cage, is a large open-air enclosure where a series of cranes has been acclimatized and remains winter and summer. At the south end is the breeding cage of the rare Cereopsis, or Cape Barren, geese, which do not care to swim.

Of the cranes, the rare and beautiful whooping crane, once abundant in this country but now practically extinct. is worth attention. The hooded sandhill and European cranes, the wonderful crowned crane of Africa, the Javan and Indian adjutants, marabou stork and several species of 


\section{THE NEW YORK ZOÖLOGICAL PARK}

heron occupy this enclosure, but the more delicate species occupy the Ostrich House and its yards. West of the Crane Paddock, two outdoor bird cages house gyrfalcons, and opposite these is a perch for the gaudy and noisy macaws.

The Goose Aviary ( 3 on map) is a long pond with three islands, on which latter are breeding houses for the birds. American flamingoes, Chilean skua, African spur-winged goose, red-breasted merganser, herring gull, white stork and other interesting species share this Aviary, and on Cope Lake to the north are the swans and Canada geese.

The northwest corner of the Park is devoted to the deer of Asia, which continent is richer than any other in species of deer. On the hill to the west of this area the herds of Indian sambar, Malay sambar, Indian thameng and beautiful barasingha deer have their ranges, faced on the south by the Colombian black-tailed species.

The Japanese sika deer occupy a slope to the east; the Indian axis deer, the most beautiful of all tropical deer, and the hog-deer of India share the Axis Deer House above, and the ranges of the fallow deer, a native of Africa but acclimatized in Europe, and the Axis Deer Range bring the visitor to the northwest or Fordham entrance of the Park.

From here it is possible to walk or take a surface car half a mile to the Fordham station of the elevated railroad, which connects with the subway at 149th Street; or, one may return through the Park to the Boston Road entrance and take the subway at 180 th Street. 


\section{THE NEW YORK BOTANICAL GARDEN}

The New York Botanical Garden was established by an Act of the Legislature of the State of New York, passed in 1891 and amended in 1894, "for the purpose of establishing and maintaining a Botanical Garden and Museum and Arboretum therein, for the collection and culture of plants, flowers, shrubs and trees, the advancement of botanical science and knowledge, and the prosecution of original researches therein and in kindred subjects, for affording instruction in the same, for the prosecution and exhibition of ornamental and decorative horticulture and gardening and for the entertainment, recreation and instruction of the people."

Pursuant to its Charter from the State of New York, the Garden is controlled by a corporation, from which managers are elected, and these, together with city officials and ex-officio scientific representatives of Columbia University and the President of the Torrey Botanical Club, constitute the Board of Managers. Except for the maintenance of driveways, which is referred to the Park Department, the control of the institution by this Board of Managers is exclusive. 


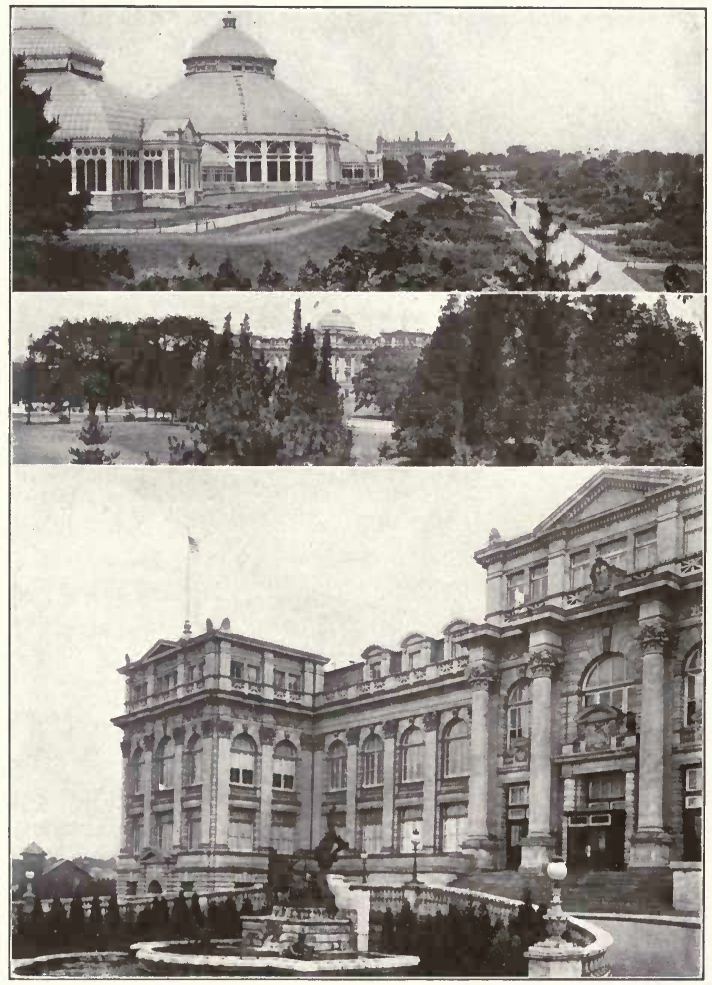

CONSERVATORY (RANGE NO. 1), NEW YORK BOTANICAL GARDEN PINETUM

MUSEUM FRONT AND BRONZE FOUNTAIN 


\section{THE NEW YORK BOTANICAL GARDEN}

Membership in the Garden includes Annual Members, who pay an annual fee of $\$ 10$, and who may become Life Members by the payment of $\$ 250$; also Sustaining Members, who pay from $\$ 25$ to $\$ 100$ annually, and Fellowship Members, who pay $\$ 100$ or more annually. Provision is also made for Fellows for Life, who may contribute $\$ 1,000$ or more at any one time, for Patrons, who may contribute $\$ 5,000$ or more by gift or by bequest, and for Benefactors, who may contribute $\$ 25,000$ or more by gift or by bequest.

The Garden, situated in the northern end of Bronx Park, New York City, includes about 400 acres, embracing a varied landscape of great natural beauty.

It may be reached in the following ways:

By the Harlem Division of the New York Central and Hudson River Railroad to Botanical Garden station.

By the Third Avenue Elevated Railway to the terminal station of that road in Bronx Park. This station is at the southwest entrance to the Garden.

By the subway: Take train marked "180th St., Bronx Park" and transfer at 149th Street to a Third Avenue elevated train, thence to Bronx Park terminal station.

By trolley car on Webster Avenue to 200th Street or the Woodlawn Road. This line connects with lines from the western part of the Bronx on Fordham Road and on Tremont Avenue and also with the line to Yonkers.

By trolley line of the White Plains road east of Bronx Park from West Farms, Williamsbridge and Mount Vernon, connecting with lines from the eastern part of the Bronx at West Farms and at Mount Vernon. 


\section{THE NEW YORK BOTANICAL GARDEN}

By driveways in Mosholu Parkway from Van Cortlandt Park; from Pelham Bay Park through Pelham Parkway; through the Crotona Parkway and Southern Boulevard from Crotona Park. There are also driveway entrances at 200th Street, convenient for those coming from Jerome Avenue; at Newell Avenue at the northern end of the Garden for those coming from the north; at Allerton Avenue on the eastern side of the Garden for those coming from the east, and at Woodlawn Road convenient for those coming from Yonkers and other points west and northwest of the Garden.

The Conservatories and Museum Building open at 10 A.M., and close at 5 P.M. in summer and at 4:30 P.M. in winter.

\section{"Come forth into the light of things; \\ Let nature be your teacher."}

Wordsworth.

The Botanical Garden includes:

1. The Largest Conservatories on the American continent for the cultivation of plants of tropical regions: one located near the entrance at the elevated railway station, and one near the Allerton Avenue entrance on the eastern side of the Garden.

2. The largest Botanical Museum in the world, located near the Botanical Garden station of the New York Central Railroad and the Mosholu Parkway entrance. This building includes, besides the Museum Collections, a large Lecture Hall in the basement, for public lectures, and, on the 


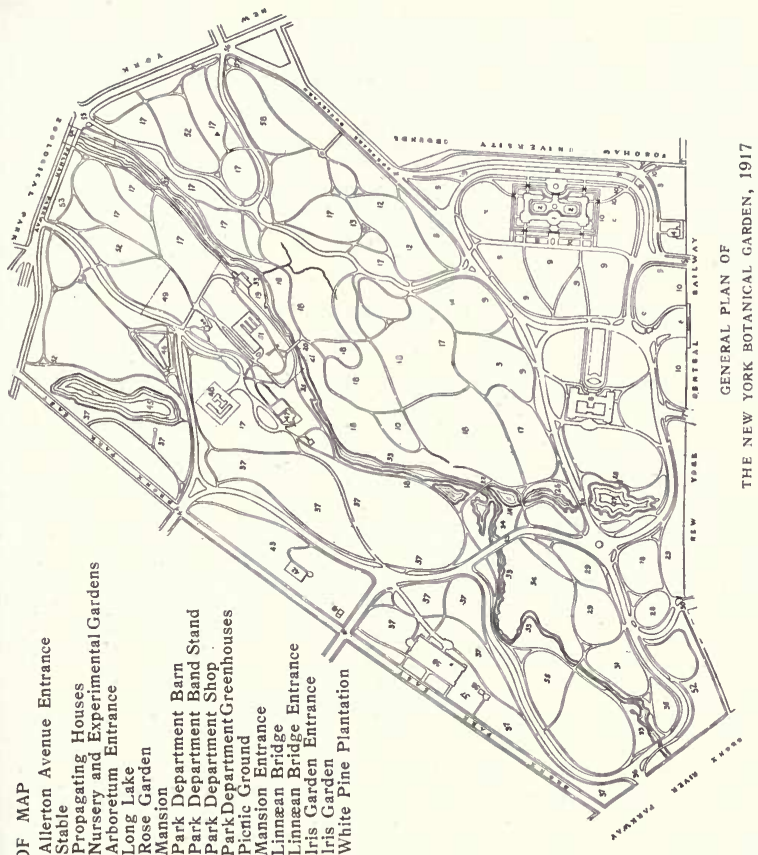

10

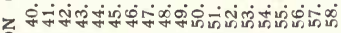

它

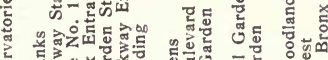

屯

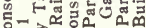

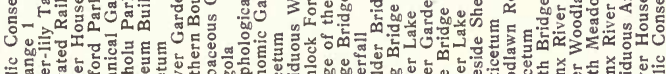
동

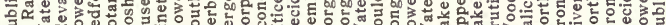

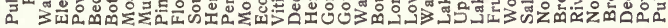

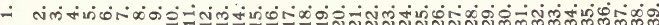




\section{THE NEW YORK BOTANICAL GARDEN}

upper floor, the Library, Laboratories for instruction and research and the Herbarium.

3. The Pinetum, or collection of cone-bearing trees, mostly evergreens, located on the hills and slopes on all sides of the Conservatory (Range No. 1) and in the space between this structure and the Museum Building.

4. The Herbaceous Grounds, situated in a valley east of the Conservatory (Range No. 1) near the Southern Boulevard entrance, containing collections of hardy herbaceous plants arranged according to botanical relationship, a collection arranged to demonstrate the principles of elementary botany, and the Economic Garden, a plantation designed to illustrate hardy plants whose products are directly useful to man.

5. The Fruticetum, or collection of hardy shrubs, located on the plain northeast of the Museum Building at the Woodlawn Road entrance and extending northward into the North Meadows. This collection also is arranged according to botanical relationship.

6. The Deciduous Arboretum, or collection of trees which lose their leaves in the autumn, located along the entire eastern side of the grounds from south to north.

7. The Hemlock Grove, clothing the hills between the Museum Building and the Bronx River and covering about forty acres, considerable portions of it being primeval. This is a natural feature of great interest, unique within the limits of a city. 


\section{THE NEW YORK BOTANICAL GARDEN}

8. The Gorge of the Bronx River extending south from the waterfall at the Lorillard Mansion along the edge of the Hemlock Grove nearly to the southern boundary of the Garden.

9. The North Meadows and River Woods along the Bronx River from the northern end of the Hemlock Grove to the northern end of the Garden.

10. The Lorillard Mansion, which contains the Board Rooms, the Office of the Horticultural Society of New York and the Museum of the Bronx Society of Arts and Sciences. On exhibition there are rare maps and prints of early New York lent by J. Clarence Davies, relics of the Indians of this section and of the early colonists, and a loan exhibit of paintings and sculpture from the Metropolitan Museum of Art.

\section{CONSERVATORY (RANGE No. 1)}

This Conservatory, located near the Third Avenue Elevated Railway terminus, is more than 500 feet in length, with a central dome about ninety feet in height. The total area under glass in this house is about one acre. It has fifteen compartments or houses:

House No. 1 contains palms of many species from all parts of the world where these occur. Among these are: The curious Mexican Acanthorhiza aculeata, which has its aërial roots modified into spines; the date palm, and the Chinese fan-palm. Related to the palms and shown here 


\section{THE NEW YORK BOTANICAL GARDEN}

by specimens is the Panama hat plant. A clump of Chinese bamboo, which belongs to the grass family, flourishes here. This plant grows with great rapidity each year from new shoots which come up from under ground, measurements showing that it has here reached the height of sixty-five feet in ninety-five days, a rate of about eight inches a day.

In House No. 2 also are to be found specimens of the palm family.

House No. 3 contains tropical monocotyledonous plants, such as species of the spider lily, maguey, Dracæna, bowstring hemp and arrowroot.

In House No. 4 are installed many large tropical plants, among which are: The interesting screw-pines with their spirally arranged leaves and prominent prop-roots; the magnificent Veitch's tail-flower, believed to be the most elegant plant of its kind in cultivation; the common rubber tree; the banyan tree; the chocolate tree; the papaw tree; the breadfruit tree; and two striking climbing vines, the night-blooming jessamine of tropical America, which opens its flowers after dark and exhales a delicious perfume, and Henderson's Allamanda of Brazil with its showy large yellow flowers.

House No. 5 is given over to desert plants,-carrion flowers from Africa, relatives of our common milkweeds, and various African species of the lily family which have developed storage organs for water. A large number of stonecrops and their relatives are to be found in this house. 


\section{THE NEW YORK BOTANICAL GARDEN}

House No. 6 is also a desert house occupied in part by the cactus family, which, with the exception of a few species, is American. The giant tree-cactus (Carnegiea gigantea) and some of the Opuntias and night-blooming Cereuses will attract attention. This house contains also the century-plants, which are limited to the New World. One of these, the sisal plant, produces the sisal hemp of commerce. The common century-plant and related species furnish the Mexican drink pulque. It is popularly believed that the century-plant does not bloom until it is one hundred years old and that it then dies. It is true that it dies soon after blooming, but it blooms in much less than a century. Other plants in this section are desert representatives of the lily family, of the pineapple family and of the spurge family.

House No. 7 contains a large and varied collection of cacti, including climbing, columnar, globose and epiphytic types.

House No. 8. Here will be found a very large and representative collection of prickly pears (Opuntia) and their relatives, including the cochineal cactus (Nopalea), upon which the cochineal insect breeds.

House No. 9. This is the aquatic house. Of especial interest is the Egyptian paper-plant or papyrus, the pith of which the ancients used in place of writing paper. On the margin of the pool are growing some plants of the sugar- 


\section{THE NEW YORK BOTANICAL GARDEN}

cane. Among the plants in the pool are water-lilies, waterhyacinth and parrot's feather.

House No. 10 contains aroids, a family represented in our native local flora by jack-in-the-pulpit, sweet-flag and skunk-cabbage; the most familiar flower in cultivation is the calla-lily, which botanically is not a lily. Among others are some handsome tail-flowers. This house is also occupied by plants of the pineapple family, many of which are epiphytic, that is, they grow upon other plants, such as trees. The Florida moss, or Spanish moss, which festoons the live-oaks and other trees of the south, is not moss but an epiphyte belonging to the pineapple family, the relationship being indicated by its flowers.

House No. 11 is known as the Banana House. Here are brought together many tropical plants, including banana, plantain, ginger, the Manila hemp, the famous traveler's tree from Madagascar and the bird-of-paradise plant.

House No. 12. This house contains plants of warmtemperate regions. Among these are pitcher-plants, and a group of insectivorous plants, the sundews; citrus fruits, including the orange and lemon; two small trees, "stinking cedar," belonging to the yew family, most interesting because it is known to occur in the wild state only in a small area along the Apalachicola River in Florida.

In House No. 13 are large specimens of plants from warm-temperate regions, including Norfolk Island pine and its near relatives; New Zealand flax; the Cherokee rose; 

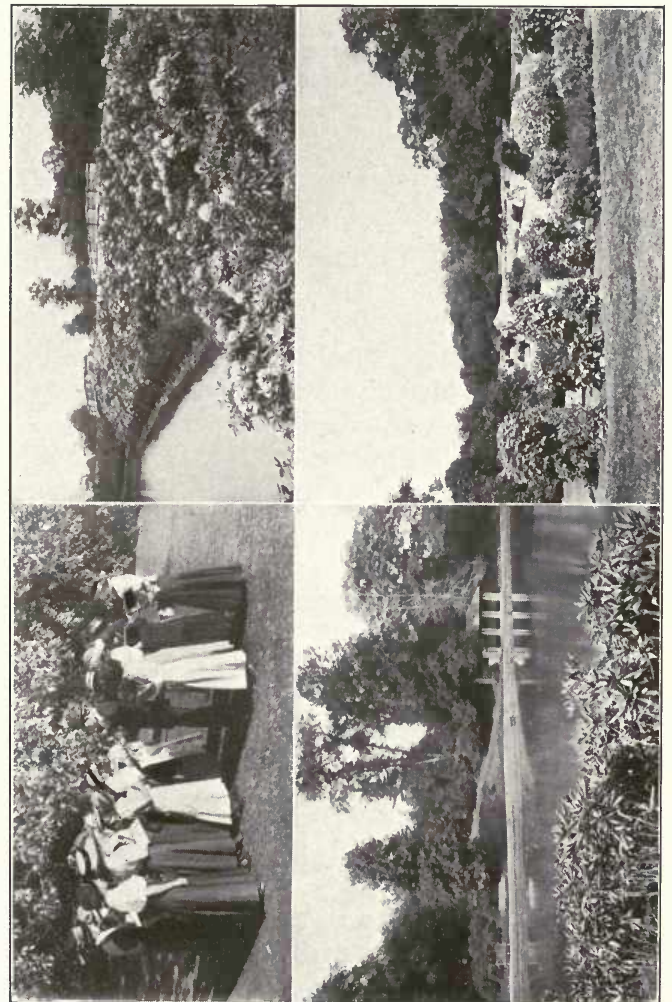

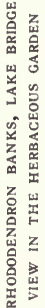

$y$

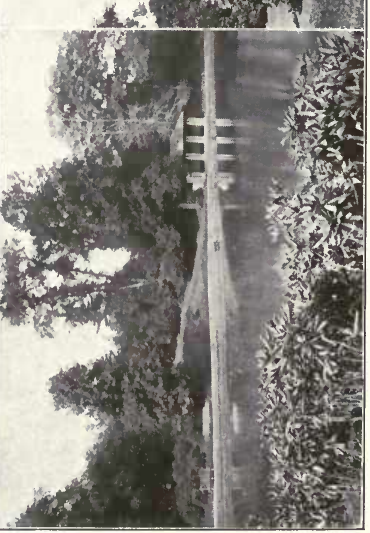

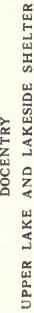




\section{THE NEW YORK BOTANICAL GARDEN}

Eucalyptus trees of Australia and Tasmania, which occur in large forests and sometimes attain a height of 200 to 400 feet, even exceeding in height, although not in diameter, the California Big Tree; camphor tree, from which the camphor of commerce is obtained; tea-plant; fig tree; olive tree.

House No. 14 contains other interesting plants of the warm-temperate regions.

House No. 15 is the Orchid House. Here are representatives from all tropical regions as well as some from the temperate regions. Most of the tropical forms are epiphytes. The vanilla plant, an orchid, may be seen here. Coming from all parts of the world, except very cold countries, as the orchids do, their blooming time varies greatly, so that at almost any time of the year some of these interesting plants may be found in flower.

Conservatory Court. During the open season here are a large collection of desert plants and a fine display of water-lilies, the latter including the American lotus and the remarkable Victoria water-lilies, whose floating leaves are circular in shape, with upturned edges, and are from four to six feet in diameter.

\section{Conservatory Flower Beds}

On the north, east and west sides of the Conservatory (Range No. 1), occupying a portion of the area below the terrace, are several large plots devoted to a display of 


\section{THE NEW YORK BOTANICAL GARDEN}

miscellaneous shrubs, evergreens and herbaceous plants. Attractive flowers may be seen here from early spring until late autumn, while the evergreens make a pleasing effect during the winter. Perhaps the most interesting flowers in these borders are the old-fashioned ones, due to the sentiment connected with our recollection of them in our grandmothers' flower-gardens. The plants are plainly labeled.

\section{CONSERVATORY (RANGE No. 2)}

Space will not permit a treatment of the Conservatory in detail. Here will be found a large collection of sagopalms or cycads and many tree-ferns, as well as many other interesting ferns and tropical flowering plants; two compartments are filled with orchids and bromeliads. The East Indian pitcher-plants are also shown here.

\section{THE BOTANICAL MUSEUM}

In the Museum Building three floors are devoted to Public Exhibits:

The upper floor contains Study Rooms, Library, Laboratories and Herbarium.

The main floor is occupied by exhibits of Economic Plants, both crude and refined products of plants used in the arts, sciences and industries. Among these are found interesting collections of food products, drugs, fibers, gums, resins, sugars, etc. 


\section{THE NEW YORK BOTANICAL GARDEN}

The second floor is given over to Systematic Botany. Here are attractive exhibits of plants representing every group from the lowest to the highest.

Installed in the basement are the collections of Fossil Plants, including those of the coal measures.

\section{The Pinetum}

In the collection of cone-bearing trees, there may be seen growing specimens from all temperate regions of the world: the Douglas spruce and the California Big Tree from western United States, the bald cypress from southern United States, Veitch's silver fir from Mt. Fujiyama, the English yew, the ginkgo or maidenhair tree from eastern Asia, and many others.

\section{The Herbaceous Grounds}

Here is a large collection of hardy herbaceous plants from all parts of the world. Part of this collection is planned to illustrate plant relationships, part to show the functions of various plant organs (Morphological Garden), and there is also an Economic Garden and a plantation of vines (Viticetum).

\section{The Fruticetum}

The Fruticetum, or collection of shrubs, occupies about sixteen acres and comprises a vast number of hardy ornamental shrubs of the world. North of this area is an 


\section{THE NEW YORK BOTANICAL GARDEN}

interesting assemblage of moisture-loving poplars and willows (Salicetum).

\section{The Deciduous Arboretum}

In the collection of deciduous trees are to be seen the English walnut, the pecan and other hickories, the birches, oaks, elms, ashes, maples, witch-hazel, sweet gum, Kentucky coffee-tree, persimmon and many others.

\section{Hours}

The grounds and buildings are open free to the public every day in the year. Visitors are not allowed within the Garden after eleven o'clock at night nor before six o'clock in the morning except upon driveways and paths designated for their use between those hours.

\section{Guides}

In order to provide a method for viewing the collections under guidance, an aid leaves the front door of the Museum Building every week-day afternoon at three o'clock, to escort all who may wish to accompany him. The routes are as follows:

Monday: Hemlock Forest, Mansion and Herbaceous Garden. Tuesday: Pinetum. Wednesday: Fruticetum and North Meadows. Thursday: Deciduous Arboretum, Nurseries and Propagating Houses and Public Conservatories (Range No. 2). Friday: Public Conservatories (Range No. 1). Saturday: Museums. 


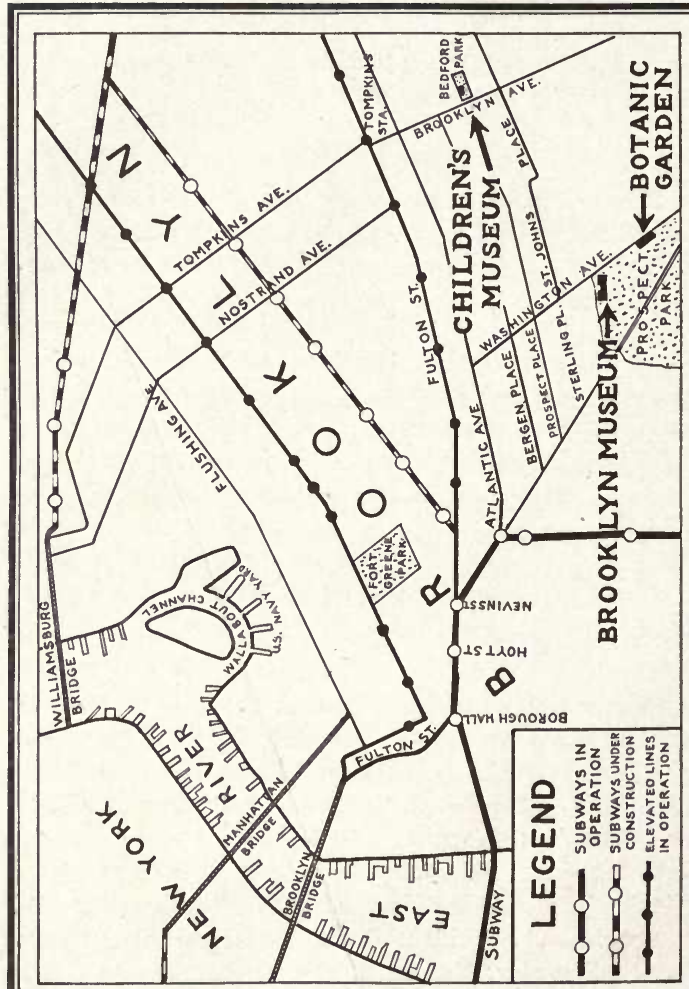

192 


\section{THE BROOKLYN MUSEUM}

A collection of birds, shells and fishes exhibited by the old Brooklyn Institute in 1854 may be regarded as the nucleus of the present Brooklyn Museum, which was organized in 1890 and is maintained as a public institution under the auspices and direction of the Brooklyn Institute of Arts and Sciences. The latter is a scientific and educational institution originally incorporated in 1824 as the Brooklyn Apprentice Library Association; it was rechartered as the Brooklyn Institute in 1843, having among its avowed purposes the establishment and maintenance of Museums and Libraries of Art and Science. The Institute is maintained by fees of its Members, private subscriptions, and in part by appropriation from the City.

The collections are provided by the Brooklyn Institute of Arts and Sciences, which raises an annual fund for this purpose, supplemented by special bequests and subscriptions.

The Museum is situated at Eastern Parkway and Washington Avenue, near the main entrance to Prospect Park, and may be reached from New York by subway to Atlantic Avenue and thence by St. John's Place car to Sterling 


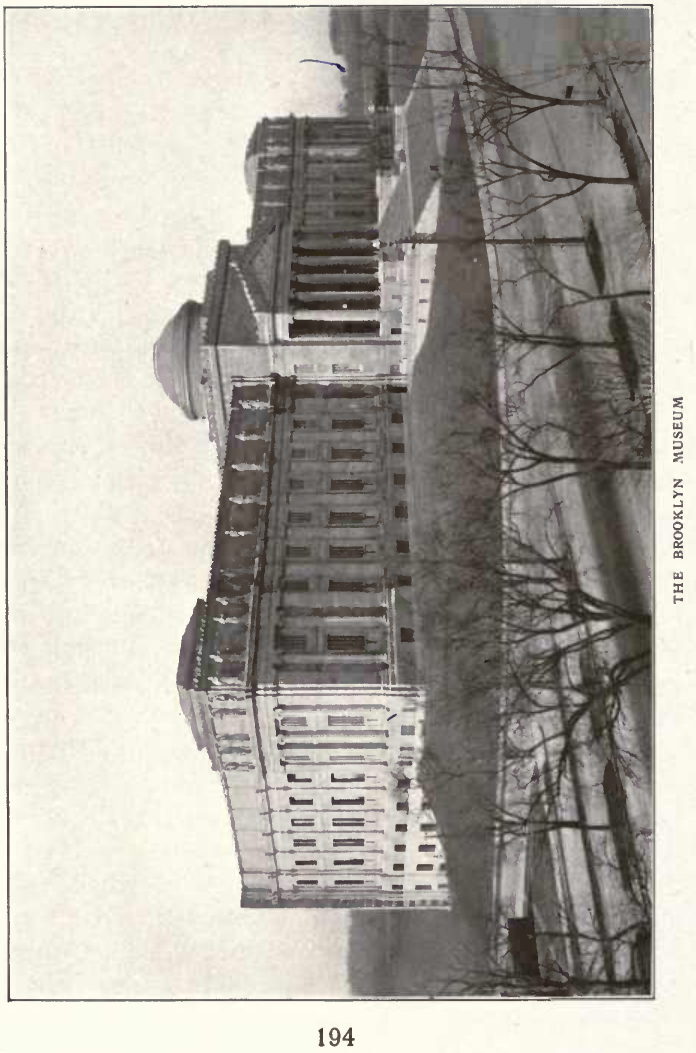




\section{THE BROOKLYN MUSEUM}

Place; or from the Brooklyn Bridge by Flatbush Avenue car to Prospect Park, and thence along Eastern Parkway to the Museum building.

The Museum is open free on all holidays and every day in the week except Mondays and Tuesdays, when a charge of twenty-five cents for adults and ten cents for children under sixteen is made. Teachers with their classes are admitted free at all times, including pay days.

Hours for visitors are 9 A.M. to 6 P.M. Monday to Saturday inclusive, Sunday from 2 to 6 P.M. and Thursday evening from 7.30 to 9.45 .

The Museum has three departments: Fine Arts, Ethnology and Natural History. For the purposes of this Guide the two latter only will be considered.

The Ethnological Exhibits are installed as follows: In the Sub-basement galleries, collections from Japan and Korea; in the Basement, specimens and collections from Polynesia, Siam, Java, Burma, Japan, China and Tibet; on the First Floor, collections from the Indians of Southwestern United States, Central and Northern California and the Northwest Coast of America, and the Avery Collection of Chinese Cloisonné. In addition, collections from East India are installed in cases on the stairway landings.

The Natural History Collections occupy the entire Second Floor.

The main entrance of the building is used only on Sundays and holidays. The week-day entrance hall is on the basement floor west of the main entrance, and from this 


\section{THE BROOKLYN MUSEUM}

point it is convenient to begin a survey of the ethnological collections from Japan.

Passing through the entrance hall, the visitor finds immediately facing him the stairway to the Sub-basement. The walls of this stairway are utilized for exhibiting a collection of Japanese spears and halberds, among them a war sickle three hundred years old; also Japanese scales and measures, prints and maps.

\section{SUB-BASEMENT}

"A mid the fragrance of the first-flowering tachibana
I recall the perfumed sleeves of the ages long past."

Old Song of Japan.

In four corridors surrounding the auditorium is a representative collection of objects relating to the every-day life of the peoples of the Japanese Empire, including the Ainu, who inhabited Japan before the advent of the Japanese, and the peoples of Korea and Formosa. A series of color prints, reproductions of photographs, and other illustrations illuminate particularly the history and customs of Japan.

At the foot of the stairway, a floor case on the left shows Japanese funeral furnishings, including models of biers and of lanterns used at graves, cremation jars for ashes, and miniature images of warriors.

The exhibits in the wall cases of this room illustrate the strict anti-foreign attitude of Japan in the early days of European invasion, showing certificates issued to various 


\section{THE BROOKLYN MUSEUM}

people stating that they were not Christians, public notices prohibiting Christianity and a permit to an English captain to visit certain forts. Christianity was introduced into Japan early in the sixteenth century, but in 1637 occurred a massacre of all the Christians in the land.

A Japanese map of the southern countries of the world, dated 1710, a picture of an ancient Japanese war vessel and a series of color prints by Japanese artists of scenes in Tokyo and Yokohama are hung on the walls of this room. The pictures of Yokohama (Japan's treaty port with the western world, and for long the only part of the Empire in which foreigners were allowed a footing) represent especially the foreigners in that city, the Sunday procession of foreigners and their entertainments being particularly interesting.

Entering the North Corridor (to right from foot of staircase), in wall cases on the right appear types of costumes worn in Japan, respectively by workmen, firemen, porters, fishermen, farmers and sailors, together with tobacco pipes, lamps, candlesticks, implements and games used by persons of various ranks, and on the left are framed specimens of textiles and loom patterns.

In studying these exhibits and those in the Japanese Hall above, it is well to remember that no country in the world, excepting China, has attached so much importance to details of dress as has Japan. Rules as to color, fabric, pattern, even to the tying of a bow, are fixed according to inviolable distinctions of rank and caste, and every class of people has 


\section{THE BROOKLYN MUSEUM}

its distinct style of costume, which has remained practically unchanged for many centuries. Fans, headgear, even sports and amusements came under these regulations, and the Museum's costume and pictorial exhibits, in this and the Japanese Hall above, are designed to provide as far as possible a representative view of the costumes and culture of the country.

Also on this wall is a series of color reproductions of Japanese costumes, from models in the Imperial Museum of Tokyo. These comprise costumes of a "Sohei," or warrior priest of the thirteenth to the fifteenth century; a hunting costume of the same date; a court dress of the eighth century; Emperor's coronation robe of the ninth to the nineteenth century; court dress of civil and military officials, in use from the eleventh to the nineteenth century, and the dancing dress of a boy noble from the ninth century onward.

A small room at the end of this corridor, the entry to which exhibits ancient maps of Japan, China and Korea, contains in a case at the right of the entry a series of painted pottery figurines illustrating the races of the Japanese Empire. Japanese, Korean, Formosan, Luchuan, Ainu, Gilyak and Crochon types are shown, also clay figurines of Korean costumes.

Two cases of Japanese lacquer work, containing lacquered boxes, chests, plates and trays, carved ivory figures and elaborately ornamented metal objects, indicate the skill and artistry of the Japanese in these lines.

The art of working with lacquer is of great antiquity in 


\section{THE BROOKLYN MUSEUM}

Japan and probably was introduced from China. The finest old lacquer was made under conditions scarcely reproducible to-day, with no thought of money value or of payment, by handicraftsmen in the service of the Daimyos (feudal lords), who worked for the sheer love of producing the most perfect work of art and craftsmanship that it was possible for man to execute. At the left end of this case is an exhibit of specimen lacquers showing the stages in the process. The finest lacquer is so hard that the surface cannot be scratched.

In metal work also, the processes employed to give decorative effects are more numerous and carried to greater perfection in Japan than in the arts of any other people. Small metal objects especially are often elaborately ornamented by damascening, chasing, inlaying, combining of metals and repoussé work. In cases at the left of the entry in this room are box handles of iron inlaid with gold, silver and cloisonné, unornamented locks many centuries old, ornamental locks, hand-pulls and other objects, which give an impression of the art of metal working as practised in Japan.

The elaborate inlaying of armor and decoration of swords and sword furnishings may be seen in the hall above.

An exhibit of ancient seals, including bronze seals for pictures and ornamental writings, wooden seals used by bookkeepers, writing materials, and water pots for mixing ink, appears at the left of the entrance in this room.

The West Corridor, at the left of this room, exhibits robes 


\section{THE BROOKLYN MUSEUM}

and garments of men and women of various ranks, toilet articles of all kinds, including rouge and rouge brushes, razors, hairpins and combs, trinket boxes and tooth brushes, color prints representing Japanese life of the fourteenth, eighteenth or nineteenth centuries and games played by girls. The case of pottery in this corridor exhibits various types of Japanese ware. Although pottery of a crude kind was made in Japan at an early period, it was not until the sixteenth century that a Korean potter came to Kioto and made a common kind of black earthenware with lead glaze, called Raku ware. For eleven generations the descendants of this man have made the same kind of ware. It is especially valued for use in the tea ceremony. The introduction of this and later of other methods from Korea and China gave a great impetus to pottery making, and many celebrated Japanese potters have since made themselves famous.

In a case on the left of this corridor is a series of objects from Korea, including arrows, helmets, apparel and other instruments of culture. The conquest of Korea occurred early in Japanese history, and many of the arts of Japan were derived from this country and through it from China.

The South Corridor at the left contains robes of Buddhist priests, labels used by pilgrims, charms and emblems to be obtained at shrines, and votive offerings. Color prints on the walls of this corridor show the game of "Suguroku." This is a game of a semi-educational nature, in which, in a series of squares surrounding a central "goal," are printed 


\section{THE BROOKLYN MUSEUM}

pictures of various types according to the subject with which it is desired to familiarize the player; in this case Japanese heroes, in others religions, famous places, etc.; many different specimens of this game are shown in these galleries.

Kites, the flying of which is enjoyed by old and young in Japan, chess, backgammon and other games, dice and toys are shown in this corridor, and in alcoves on the left are reproductions of antiques and art treasures from the Imperial Treasure at Nara. Nara was the residence of the Mikados from A.D. 708 to 782, after which the court was removed to Kioto. At the time of the removal, the Imperial furniture and property of all kinds were stored in the large wooden storehouse, "Shoso-in," built for the purpose. Here it remained packed in wooden chests for nearly 1,200 years and is now exhibited in corridors surrounding the temple. This celebrated collection of antiques and curios includes books, sculptures, screens, pottery, masks, copper bowls, ornaments, weapons and utensils of all kinds, as well as dresses and fabrics. The larger part of these are of foreign origin, many of them Chinese.

In a case at the left of this corridor, an exhibit of bows and arrows shows practice, hunting and ceremonial arrows, arrows in different stages of manufacture, practice and long distance bows and a crossbow four hundred years old. The arrow has an important place in primitive culture, and those of each individual bear his name, except in the case of war arrows. They are used ceremonially for purposes 


\section{THE BROOKLYN MUSEUM}

of divination. Small arrows were used in playing a game, and Korean playing cards still bear representations of the arrows from which they were derived. Opposite this exhibit is a case of spear heads.

An exhibit of articles from Formosa, comprising baskets, hats, palm-leaf clothing, weapons and other objects, occupies a case at the east end of this corridor, followed by an exhibit of carved wooden implements from the Ainu. These peoples, who inhabited Japan before the advent of the Japanese and probably once occupied the greater part of the country, are now confined almost entirely to the Island of Yezo in northern Japan. Their culture was that of the Stone Age, characterized by the entire absence of metal. The east corridor on this floor contains exhibits of Ainu culture showing looms and methods of weaving rough fabrics from elm-tree bark, heads of the deified bear, carved knife sheaths, pipe holders, tobacco boxes and moustache lifters, models of boats and canoes, and utensils. 


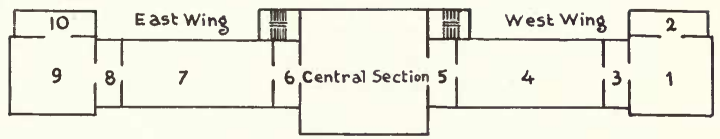

\section{BASEMENT FLOOR}

The entrance hall to this floor (Room 5 on plan) is lined with cases exhibiting robes and headgear of Japanese court ladies of the early nineteenth century. The court dress of Japan is fuller than the ordinary clothing and unconfined at the waist. The Empress's robe, called "go-i," or robe of five thicknesses, is of silk damask made in five thicknesses on the edges of the sleeves and skirt, so as to give the appearance of a number of robes. Both winter and summer styles of "go-i" are exhibited. Color prints and wood carvings are displayed on the vacant wall space of the entrance hall, which gives access, through a passage on the left, to the main Japanese Hall.

A pair of sliding temple doors, painted by an artist of the Kano School in 1750, are shown in the entrance to this hall, and the hall itself (Room 4 on plan) has been designed, decorated and lighted with a view to suggesting the atmosphere of the Island Empire. A particularly rich and representative assemblage of armor, weapons, costumes, objects connected with religion, musical instruments, games and writing implements, together with Japanese books, color prints and other illustrated material, is to be seen 


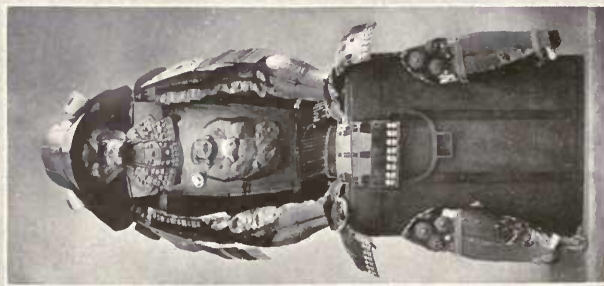

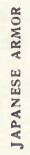
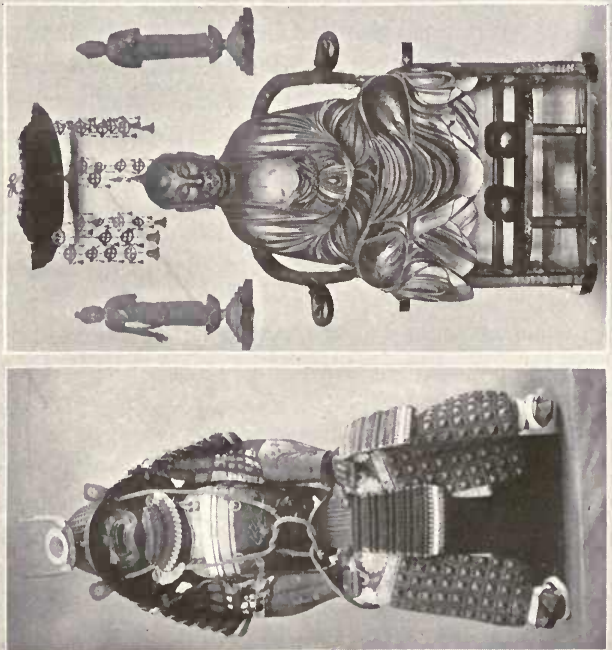

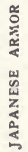




\section{THE BROOKLYN MUSEUM}

here; the central aisle divides the hall into halves, the right or south side being devoted for the most part to military costumes, accoutrements and paraphernalia and color prints representing war, while the other side is given over to civil, ceremonial and religious costumes and objects relating to the arts.

At the right of the entrance two large cases are devoted to an exhibit of dolls used in the annual celebration of the "Hinamatsuri," or dolls' festival, on the third day of the third month. This is the girls' fête day, when dolls representing historical characters, studiously exact in every detail, and with attendant servitors, vassals, equipages, etc., are marshalled by the children. The making of these costly dolls provides employment for many artists, and collections of them are handed down from generation to generation. The idea on which the festival is based originated in China as a rite for exorcising evil spirits, consisting in rubbing one's self with a puppet provided by the exorciser. Family puppets were later ranged in a shelf, and out of this grew the Japanese festival.

Beside and behind these cases a fine collection of ornamented swords, sword hilts, scabbards and mountings may be seen, adjoining exhibits of spears, spear racks and chain armor. The inlaying of armor with gold and silver began in Japan in the twelfth century or earlier, but sword decoration not until the fifteenth century.

The majority of the high floor cases on this side of the hall are utilized to display a very remarkable collection of 


\section{THE BROOKLYN MUSEUM}

Japanese armor. War drums, war fans, war horns, masks and bells, with the warrior's lunch box, pencil case, camp stool and water cup, give a comprehensive idea of an ancient Samurai equipment, and toward the eastern end of the hall a lacquered wooden saddle with bridle reins and horseman's dipper complete the cumbersome regalia with which the warrior took the field.

A hunting hat, worn by a Daimyo, or feudal lord, with implements and apparel for archery, and a complete hunting costume are also shown.

In the second of the large floor cases from the western end of the hall on this side will be found prehistoric relics from the dolmens, or rock chambers, covered with mounds, in which the early Japanese buried their dead. Many interesting objects have been found in these chambers, indicating an advanced stage of culture. Pieces of gold-plated iron harness, trappings, swords, bronze arrow-heads, ceremonial stone axes and carved jewel stones of the curious curved type called "magatama" are shown in this case. The latter belonged to an age of culture before the immigration of the Japanese, but were much prized ornaments in Japan well into the historic period. Nine color prints by Japanese artists, of ancient Japanese battle scenes, occupy part of the wall space on this side of the hall. A collection of war masks is exhibited above them, and to the right is a fine collection of seventeenth century helmets. Next to this an exhibit of weapons includes several ceremonial and other swords, some elaborately chased and decorated. 


\section{THE BROOKLYN MUSEUM}

Exhibits connected with the Buddhist religion, including images, temple ornaments, plates, lamps, miniature shrines, rosaries and other ornamental and ceremonial objects, occupy the three remaining wall cases on the left-hand side of the hall; and on each side of the hall at this end a series of images of "Rakan," or disciples of Buddha, is shown seated around a raised dais, as in Japanese temples. A carved alms chest from the Nichiren temple faces these on the right side of the room, and below it is a case of fans used by priests.

The floor cases on the opposite side of the hall, beginning at the western end, exhibit drums, bells and rattles used by priests, pilgrims and mendicants, or in ceremonial dances, including a rattle bell used in dancing the Kagura. This is a very ancient Japanese religious dance associated with Shinto ceremonials. A gong used in the Bakabayashi, or music performed at festivals, is also exhibited here.

A collection of Japanese musical instruments, showing flutes, pitch pipes, whistles, clarinets and drums, many types of flutes and the Chinese "biwa," is exhibited in this case and in others on the adjacent walls, together with books of classical music, color prints showing dancers of the Bugaku, a musical dance of the Imperial Court, and headdresses worn in connection with dancing and music. The flute used to accompany the No dance and the ceremonial headdress, or kammurai, worn in this dance, are interesting because this is the religious ceremonial dance adopted from the old Shinto Kagura by the Buddhist priests; it 


\section{THE BROOKLYN MUSEUM}

came into high favor with the aristocracy and was the foundation of the Japanese drama. Brocaded kimonos used in this dance are shown in a wall case on the right.

Down the hall are robes, headgear and other apparel worn by nobles, including football costumes and balls. Football was a game especially for the nobles and consisted in keeping the ball high in the air, no goals being used.

The Ho, or principal outer robe worn by nobles as a ceremonial dress, dates from 300 A.D., when the dress itself and the silk to make it were imported from China, different colors and patterns signifying different ranks, that of the prince of the blood being yellow. Various examples are exhibited, together with fans, stockings, hats and ceremonial scepters used by nobles. No noble below the fifth rank could use an ivory scepter. Cups and bowls once used in the Imperial Household are also shown here.

Still farther down the hall the cases are devoted to exhibits relating to the Shinto religion, the original and essentially Japanese religion of the country. These include robes, hats and fans of priests, Shinto shrines and offerings, and "makimono," or rolls of color prints representing religious processions. Ancestor worship, one of the main tenets of this religion, probably arose from some form of nature worship, and the key-note of its outward observance is simplicity, no graven images, color or carving being employed in Shinto temples and shrines, whereas in Buddhist temples richness of decoration and appurtenance is the rule. Buddhist books, paintings, costumes, hangings and other 


\section{THE BROOKLYN MUSEUM}

objects are shown in cases at the lower end of the hall, and an elaborate miniature Buddhist temple of the type kept in private houses occupies a case to the right of the entrance here. Behind this are shown ceremonial weapons, baton, scepters, incense boxes and other objects used by Buddhist priests, and, next to these, objects used in Japan by fortune tellers, palmists and other diviners of the future.

On the wall, on this side of the hall, an exhibit of toys and games includes the popular battledore and shuttlecock, tops, balls, skates and polo rackets, and a series of twelve color prints represents various children's games, appropriate respectively to the twelve months of the year. Another set of color prints represents the Japanese version of the birth of Buddha, and at the western end of this very interesting exhibit is a case in which colors, brushes and blocks used in Japanese color printing are shown. Among these a set of eight old wooden blocks for a color print, with sixteen impressions showing stages in the printing, together with the finished print, are especially instructive.

Ascending the steps at the western end of the Japanese Hall into Hall 3 , the visitor finds exhibits from Siam, Java and Burma. Two wall cases on the right contain objects from Siam, including many Buddhist images, decorated betel-nut boxes and porcelain gambling counters.

On the left, a case of objects from Burma shows games, weapons and objects connected with Buddhism. Beyond, an exhibit from Java contains for the most part weapons and musical instruments. 


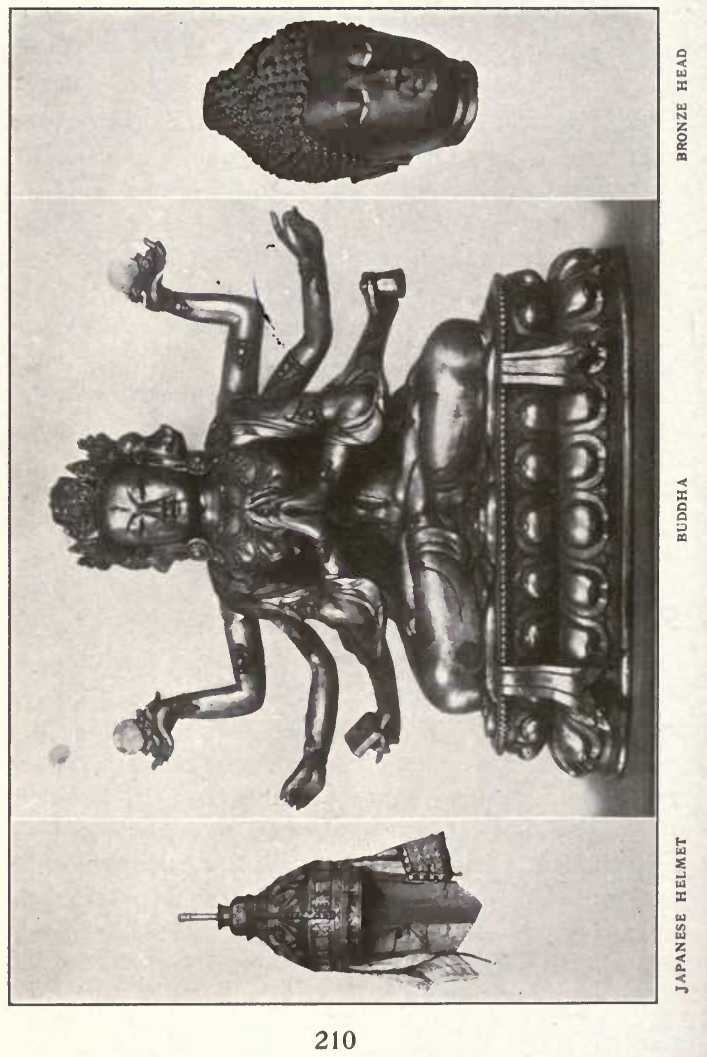




\section{THE BROOKLYN MUSEUM}

A set of Burmese playing cards is exhibited on a doorway on the left of this hall.

Proceed into Hall 1, which contains collections from the South Pacific Islands.

The two central floor cases here are devoted to objects of Hawaiian culture, consisting of stone implements, wooden platters, ornaments and images. The implements for making "tapa" or bark cloth from the bark of the paper mulberry form an interesting part of this exhibit. Specimens of black bark cloth, used for wrapping the dead, white for new-born children, and a many-layered "tapa" used as a bed sheet are shown. Among the Pacific Islands tapa making reaches highest perfection in Hawaii, and in cases on the west wall and alcove of this room is a series of fine specimens of Hawaiian tapa ornamented with various native designs in black and color.

A case of native spears will be seen at the back of the hall, and behind the elevator a Haida Indian totem pole, placed here where the staircase provides for its great height.

On the east wall of this room are shown exhibits from New Zealand, the Hervey Islands, Samoa and the Marquesas Islands, among which may be mentioned a carved ceremonial adze and paddles from the Hervey Islands, and the large wooden images from New Zealand carved to simulate "moko" or tattooing.

The Gilbert Islands and New Britain Archipelago are also represented by cases on the east wall, containing native masks, headdresses, armor and implements. 


\section{THE BROOKLYN MUSEUM}

Opposite these on the west wall a case of specimens from the Fiji Islands shows tapa, fish hooks, wooden bowls for drinking the native drink, "kava," and other articles.

In all these cases reproductions of illustrations taken from "The Living Races of Mankind" serve to give an impression of the natives from whom the exhibits are derived.

The greater part of these South Pacific collections belonged to the late Appleton Sturgis and are lent by his son.

Returning to the Elevator Hall, the visitor will find the entrance to the Chinese gallery immediately facing the stairway to the Sub-basement. Here, in a series of wall cases, is displayed a fine collection of Chinese court, military and ladies' costumes, headdresses and ornaments, together with a large number of other objects illustrative of Chinese civilization.

Vases, charms, chopsticks, spoons and other utensils, musical instruments, tea and wine cups, toilet articles, games of many kinds, writing utensils, lottery diagrams, pipes of all kinds, opium outfit, rosaries, incense holders and other objects connected with religion, bronze spear heads, weights, weapons and art objects make up an exhibit interesting alike to the student or the casual visitor.

At the eastern end of the Chinese Gallery is a smaller room devoted to an exhibit from Tibet, consisting of Buddhist pictures done on silk and Buddhist images.

The Museum Library, in which may be consulted a large number of works of reference bearing on the various collections, is at the extreme eastern end of this floor. 


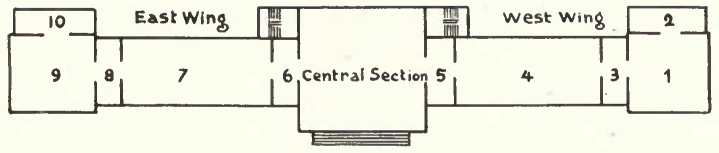

\section{MAIN OR FIRST FLOOR}

The Avery collection of Chinese cloisonné enamels, considered to be the finest collection of its kind in the United States, is included among the exhibits of the Department of Ethnology and is arranged in a series of cases at the south side of the central portion of the hall.

The distinguishing feature of cloisonne enamels is that the vitreous pastes are separated by partitions formed by soldering thin upright ribbons of metal to the metal ground, the sections between the partitions holding enamel of different colors, laid on in the form of paste and fused by firing. The art was practised by the Egyptians, Greeks and Romans and handed on by them to the Byzantines, from whom it was borrowed by the Chinese in the fourteenth century, its later development being practically confined to the Chinese and Japanese.

The four halls comprising the western portion of the main floor of the Museum, reached from the Avery collection by ascending a few steps to the west, contain the collection from the Indians of Southwestern United States, Central and Northern California and the Northwest Coast. 


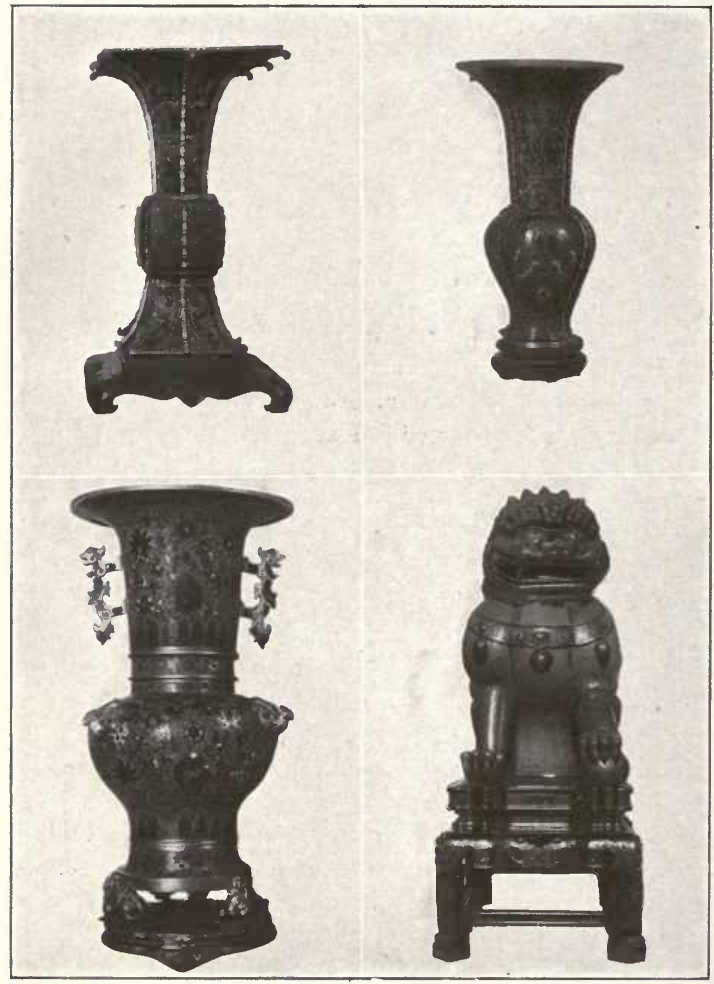

CHINESE CLOISONNÉ-AVERY COLLECTION

214 


\section{THE BROOKLYN MUSEUM}

The first of these halls (Room 4 on plan) is devoted to exhibits illustrating the customs, arts and industries of the Indians of the Southwest, and of these the Zuñi, an agricultural tribe occupying the pueblo, or town, of Zuñi in western New Mexico, have been selected for particular attention, as being in many respects representative of all.

All the exhibits on the left (south) side of the hall are drawn from these people. Those on the north side are from tribes adjacent to the Zuñi: the Navajo, Apache, Hopi and the prehistoric cliff-dwelling Indians from Cañon de Chelly in Arizona. The collections consist of masks, dolls, weapons, ceremonial objects and musical instruments used in the ritualistic dances which form an important part of Indian life; implements used in the various industries, games, costumes, ornaments, pottery, snares and weapons of the chase.

At the east end of the hall, a map of the ancient Spanish province of Cibola, which includes the Zuñi country, is exhibited over the entry. In 1648, a mission was established by the Spaniards among the Zuñi, and they dwelt for many years under Spanish influence. Many exhibits illustrating this influence, as distinguished from those of purely Indian origin, will be found on the south wall, including relics from the old Spanish churches, wooden door and window frames, mallets, shovels, bow and gun racks and iron tools.

The first of the large floor cases on the left side of the hall exhibits carved wooden columns from the old Spanish church and specimens of adobe brick from which the church 


\section{THE BROOKLYN MUSEUM}

and some of the houses in Zuñi are made; also fetiches and charms and a collection of masks worn in dances. These ceremonies are designed to secure rain, produce crops or achieve healing. In them the priests of the various secret societies personate the gods, each god requiring a differently made or painted mask and costume. The masks are of five general types but exhibit great variety. Similar masks are found among the Hopi, Keres, Tewa and other pueblo tribes of the Southwest, in representation of the same gods. The same mask may be used in different dances, being painted, however, according to the requirements of each. Firearms have superseded the primitive bow and arrow, club and shield of the Indians, which are now used only in ceremonial dances.

At this end of the hall is a model of Montezuma's Well near Cape Verde, Arizona, a circular depression with naturally perpendicular walls, in which are several cliff dwellings. It is one of the most interesting sites of Indian habitation in the Verde Valley, and is claimed by the Hopi as the home of their ancestors.

The representations of Zuni altars, shown among the masks in two of the cases, and the labels referring to them and to Zuñi secret societies, should be studied in connection with the color sketches of shrines on the south wall and with the bells obtained from shrines shown in cases farther down the hall.

The Zuñi have thirteen secret societies, to one or the other of which the greater part of the population belongs. 


\section{THE BROOKLYN MUSEUM}

The chief object of these societies is to heal the sick and produce rain. They meet in different houses in the large ground-floor living rooms, the walls of which are symbolically decorated with animal paintings. Reproductions of the painted walls of two of these fraternities are shown in these cases. Each society has one or more shrines on the mountains near the town, and prayer sticks, made by the members at their various festivals, are deposited in them.

Tools, dies and materials used in Zuñi silver working are shown in a case opposite the portrait of Mr. Cushing in the middle of the south wall. This is a comparatively recent art learned from the Mexican Indians or from the Navajo. The tools exhibited belong to the Zuñi smith, Lanyati, who learned the art from a Navajo Indian. An exhibit of Navajo silverwork is shown in a case on the south side of the hall immediately opposite and forms an interesting comparison. Proceeding down the hall, dolls and musical instruments are the important features of the cases next following.

Zuñi dolls are made to represent the variously grouped and masked personators of the gods in the religious ceremonies, and are presented by the dancers to the girl children among the spectators, the idea being to impart religious instruction. The dolls exhibited represent the entire range of Zuñian mythology.

The principal musical instruments of the Zuñi are flutes, rattles and drums. Two kinds of flutes, with and without holes, are used, the latter only as dance flutes. Rattles are of seven kinds, gourd, shell, deer hoof, duck, tortoise shell, 


\section{THE BROOKLYN MUSEUM}

bangle and deer bone. Gourd rattles are used in all dances and the others on specific occasions. Drums are of three kinds, jar drums, wooden and sheepskin drums. Examples of each are exhibited.

Turquoise pebbles and beads and other ornaments in which turquoise is used are shown in an adjacent case, followed by an exhibit of stone implements, pottery paint, implements for making shell beads, samples of corn and other food seeds and implements used in games. Games are important in the life of the Zuñi, and, like most of their occupations, are sacred. Their four principal games, two chance games with dice and two guessing games, are sacred to the Twin War Gods, and the implements used in them are annually sacrificed on their shrines. The principal athletic game is the kicking billet. Quoits were also used, derived from the Spaniards.

Zuñi decorated pottery, shown in the next case, is made only by the women in summer. The method of making it is outlined in the attached labels.

Fetiches and charms mainly compose the next exhibit. Small images of stone and shell in the form of animals and called wemawe, or "prey gods," were made by the Zuñi and treasured as charms. Naturally occurring concretions or petrifactions were especially valued and believed to have magic power. The six regions of the world were supposed each to be guarded by a presiding animal, and the animal fetiches kept by the priests were valued as mediums between them and the creatures represented. 


\section{THE BROOKLYN MUSEUM}

Prayer sticks, images, parts of an altar and other objects from the Chukati shrine, an old cave shrine of the Little Fire Society, together with sacrificial war clubs, miniature pottery vessels and other objects taken from shrines, are shown in the succeeding cases. The last case on this side of the hall contains exhibits of Zuñi basketry, cooking and other implements, plume boxes and household articles.

A model of the pueblo of Acoma, a town of the Keres Indians in New Mexico, and the oldest inhabited settlement in the United States, is exhibited at this end of the hall, and on the other side of the hall is a model of the Tewa village of Hano. Other exhibits from the Keres and Tewa Indians will be found in Room 3 .

The remaining exhibits in Room 4 are derived from the Hopi, Apache, Navajo and prehistoric cliff-dwelling Indians.

Those from the Hopi, whose seven towns are located within the Navajo Reservation in Arizona, are at the west end of the hall and consist principally of masks, dolls and implements for games, similar to those of the Zuñi, also blankets and wearing apparel, in the weaving, dyeing and embroidering of which the Hopi are particularly skilled.

Fragments of ancient Hopi masks and pottery found in a case of the Cañon de Chelly are of special interest as showing that it was once occupied by one of the Hopi clans.

A very large and important collection, from the prehistoric cliff-dwelling Indians of the Cañon de Chelly, occupies the greater number of the cases on the north side of the hall, as well as all the shallow cases on the north wall. 


\section{THE BROOKLYN MUSEUM}

This cañon, well known for its cliff ruins, is in the heart of the ancient pueblo region in the present Navajo Indian Reservation in northern Arizona. Its vertical sides of red sandstone, in some places more than 800 feet high, with natural recesses in the rocks and with small cultivable areas at the bottom, made it a natural residential stronghold for the lndians, who built their houses high up in the caves. The first settlements there are very old, the last quite recent, and it is uncertain whether the occupancy of the cliffs began 500 or 5,000 years ago. The dry climate has preserved the remains of the cliff-dwellers extremely well, and they throw interesting light upon the life and customs of the Indians before the time of foreign contact. A large collection of cliff-dweller pottery is exhibited, the cooking pots and storage jars being of simple coiled ware left unsmoothed and showing in their structure the method of manufacture, the finer kinds of pottery being smooth and decorated. The stone and bone implements used by the cliff-dwellers who lived in a Stone Age, their basketry and weaving and the raw materials used for these are exhibited, as well as human remains, excavated from graves, wrapped in yucca cord blankets and covered with baskets. Remains of domestic turkeys and eagles, the latter kept for their feathers, are also shown. This fine collection and the mass of illustrative material accompanying it make possible a comprehensive study of the life of the primitive Indian.

The remaining cases on the north side of the hall are devoted to collections from the Navajo and Apache. These 


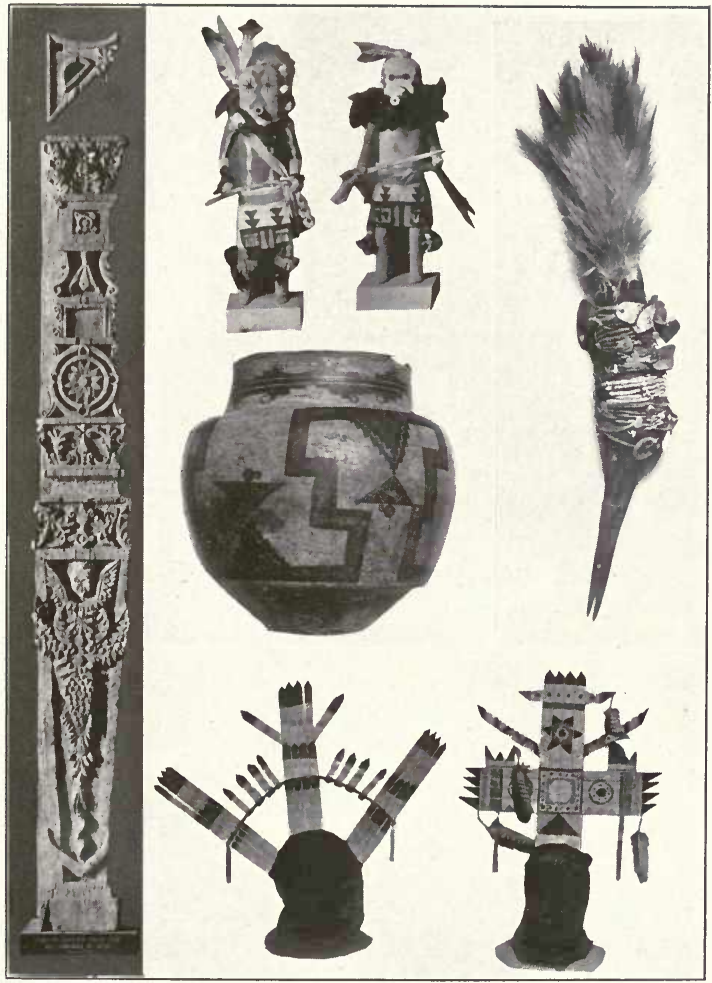

ZUÑI, APACHE AND NAVAJO INDIAN SPECIMENS 


\section{THE BROOKLYN MUSEUM}

peoples did not live in towns like the Zuñi and Hopi, but in scattered dwellings, and are comparatively late comers to this region. A set of masks used in the ebichai, or "Dance of the Giants," is shown in the case at the extreme northwest corner of the hall. A life-size model of a Navajo medicine man in native costume, with his medicine bags beside him and a "bull-roarer" in his hand, is shown opposite the entrance at this end of the hall. The contents of a medicine bag and a collection of objects used in the healing ceremonies are shown in a near-by case.

A collection of objects found with the remains of a band of Navajo killed in the Cañon del Muerto, or "Cañon of the Dead," dates from about the end of the eighteenth century. This cañon is a branch of the Cañon de Chelly, and its name is derived from the number of bodies of ancient peoples found interred there. Pottery, weapons, games, spindles, arrows and utensils are comprised in this exhibit.

The collection from the Apache Indians consists of implements for games, dance masks, weapons and basketry. These Indians are skilled in the latter art and trade their products with other tribes.

In addition to the collections already mentioned, the north side of the hall at its eastern end exhibits a model of a triple-walled town near McElino Cañon, Colorado, and small cases at intervals down this side of the hall exhibit pottery from cliff and pueblo dwellers of Colorado and Utah, relics from prehistoric Indians of Arizona and from the Mohave, Papago and Maricopa Indians. 


\section{THE BROOKLYN MUSEUM}

The mural paintings in this hall give a panoramic view of the regions from which the collections came.

The collections from the Indians of the Rio Grande pueblos, exhibited in Room 3, are from the Keres, Tigua, Jemez and Tewa Indians. These collections follow immediately those in Room 4 and complete the series of exhibits from the southwestern tribes.

Laguna is the most recent of the new Mexican pueblos, and its inhabitants are of mixed origin. An impression of its appearance is given by various color sketches.

A collection of prehistoric pottery and other antiquities from Arizona is also included in this hall.

Maps, color sketches and other illustrated material are provided as in Room 4, and the mural paintings are landscapes representing the territory.

In the central floor space at the left or southern end of the room are two models, one of the panther statue and enclosure of the Keres Indians near Cochiti, New Mexico. Two life-size images of panthers lie in a stone enclosure near a ruined pueblo. These are the largest images known to have been executed by pueblo Indians, and nothing similar to them and their enclosure has been discovered anywhere in the Southwest outside of the territory of the Keres. The images are fetiches of the esoteric group of the hunters. The other model represents the pueblo of Taos, New Mexico, the ancient home of the Tigua Indians, located on the Taos River about fifty-two miles northeast of Santa Fé. It was first visited by the Spaniards in 1540. 


\section{THE BROOKLYN MUSEUM}

An exhibit of pottery from the prehistoric Indians of Arizona occupies a case at the left of these models, and at the right objects from the Keres Indians of Laguna include masks, moccasins, stone implements and fetiches.

On the right side of the hall the center floor cases exhibit pottery of the Tewa, Keres and Tigua Indians, to the left of which is a collection of pottery and antiques excavated from prehistoric Indian graves near Fort Defiance, Arizona. This pottery is the ordinary domestic ware, very similar to that found in the Cañon de Chelly. Much of it is decorated, and the cooking pots were made by the coil process. With the skeletons were found bone awls, ornaments, paint and other objects, among which a prehistoric copper bell and a decorated clay pipe are especially interesting.

The case on the east wall at this end of the hall contains prayer sticks, stone implements and other exhibits from the Jemez Indians of New Mexico, and in the same case are games, implements, fetiches and shrine offerings from the Keres. Games of the Tewa Indians are also shown here. Miscellaneous objects from the Keres Indians find a place on the shelves above.

The California Indian Hall (Room 1 on plan) is entered from Room 3 from the west, and contains collections from five different tribal groups. These are the Pomo Indians of Mendocino and Lake Counties, the Maidu of Plumas County, the Hupa Valley and Klamath River Indians of Humboldt County, the Mono of Madeira County and sev- 


\section{THE BROOKLYN MUSEUM}

eral tribes of the Mariposan linguistic stock in Fresno, Tulare, Kern, Mariposa and King Counties, California.

The exhibits from the Maidu occupy three cases at the left or south side of the hall and comprise basketry, games, dance accoutrements, ornaments and other objects.

The most important collection in this hall is that from the Pomo Indians of Clear Lake, which occupies the remaining cases on the south side and some of those on the north side of the hall. Basketry, textiles, tools and materials used in native manufactures, implements, costumes, games and beadwork are shown. An interesting part of this exhibit is a set of doctor's paraphernalia, containing specimens of dried mud puppy, coyotes' feet, medicine stones and other native remedies.

An ancient duck-shaped boat of the Pomo is exhibited, and an immense Pomo acorn storage basket, with scaffold and ladder to reach the top, is at the west end of the hall. Acorns formed the principal article of diet of these Indians, and many of their stone implements arè designed for crushing and cracking them.

The exhibits from the Miwok, Mono, Hupa, Yokut and Klamath Indians on the north side of this hall are of the same general type as those from the Maidu and Pomo. A sweat-house ladder of the Hupa Indians, used for descending into the small underground chambers for the steam bath, is shown in the northwest corner of the room. Baskets for the Indian game of basket-ball are shown in the case devoted to the Miwok Indians. The mural paintings 


\section{THE BROOKLYN MUSEUM}

in this hall represent a view on the shores of Clear Lake, one of the ancient homes of the Pomo Indians, some of whom still reside in the vicinity.

Collections from the Indians of the Northwest Coast contained in Room 2, entered from Room 1 from the south, are derived from the Haida Indians of Queen Charlotte Islands, the Kwakiutl and other tribes of the Wakashan linguistic family of Vancouver Island and the coast of Washington and the Salish Indians of the Fraser River region in British Columbia.

Exhibits from the Kwakiutl include four large carved and unpainted house posts, shown on the east and south walls of this room, from an old Kwakiutl house at Alert Bay, Vancouver Island.

Two other house posts of the Kwakiutl are shown at the west end of the hall, and a carved memorial figure, also from the Kwakiutl, representing the "Speaker" at a ceremonial feast, is exhibited near the entry on the north side. Other exhibits from the Kwakiutl and tribes of the same linguistic family are shown at the east end of the hall and include basketry and weaving materials, games, household utensils, ceremonial food dishes inlaid with opercula, and other objects.

Exhibits from the Haida Indians include a series of models of Haida houses, copies from actual houses in the village of Masset, Queen Charlotte Islands, ranged around the walls on an upper shelf. These houses each have a tall carved totem pole in front of them, and the actual 


\section{THE BROOKLYN MUSEUM}

totem pole which may be seen in the elevator shaft, at the end of Room 3, was taken from the same village.

The mural paintings in this hall represent the village of Masset and show a series of these Haida houses ranged along the banks of a lake.

The case of exhibits from the Haida on the southwest wall contains painted basketry, hats, carved and painted wooden helmets, food dishes, carved spoon, stone, slate and wooden dishes for grease and berries, basketry mats and other objects.

From the Salish Indians, basketry, implements and materials used in its manufacture, beads, utensils, dried roots and fruits, stone and wooden tools and other objects are shown in a case on the north wall. Maps, color sketches, prints and other illustrated material on the walls and in the cases supplement the impression made by the exhibits. 


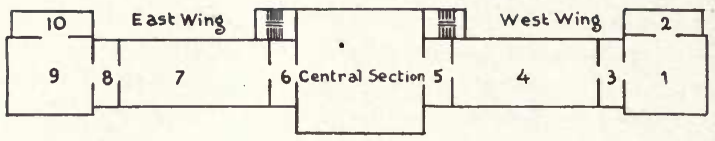

\section{SECOND FLOOR}

Ascending to the second floor, the visitor passes exhibits of fabrics, musical instruments and other objects from East India. The entrance to the Natural History Collections is flanked on either side by the bronzes, by Carl E. Akeley, of an African elephant group and a lion and buffalo.

The room directly at the left from the elevator (Room 5 on plan) forms the best point of departure for a study of these collections. It contains exhibits illustrating the Evolution, Distribution and Preservation of animals, designed to indicate the manner in which new types and species have come into existence; various ways in which animals may become adapted to environment, and how the present distribution of animals has been brought about. The latter point is illustrated by maps on either side of this room, as one enters, and over the doorway inside, showing the extent and relations to one another of the continental areas at different epochs of the world's history, and the zoölogical regions of the world as they are to-day, thus indicating how animals in the past have been able to travel by land between regions now separated by sea. 


\section{THE BROOKLYN MUSEUM}

Portraits of Darwin and Huxley, the men most prominently associated with the theories of evolution and survival of the fittest, are placed in the entry of this room. On the left an exhibit dealing with man's place in nature shows, by comparison of human skulls with those of other members of the Order Primates and by models of brains and casts, how man differs from and approximates other species of his order, and, by comparison of skulls of different races of mankind, how man varies within his own species.

On either side of the entry are exhibits showing on the one hand Protective Coloration in insects, by examples whose color and markings blend with their natural surroundings, and on the other Mimicry of harmful by harmless insects for protection.

What may be termed a refinement of protective coloration is shown in an exhibit immediately opposite the entrance, illustrating obliterative shading. This shows a flock of birds, some of which, though identical with the background in color and markings, stand out from it clearly because of the effects of natural light and shadow, and others, which, though unlike the background, are shaded so as to counteract these effects and are less noticeable.

Above this exhibit is shown a mounted skunk in its environment, to illustrate ruptive coloration, or the way in which contrasted marking of an animal may break up its outline and render it less distinguishable.

Variation Within the Species constituted the starting point for the production of new species, and on the west 


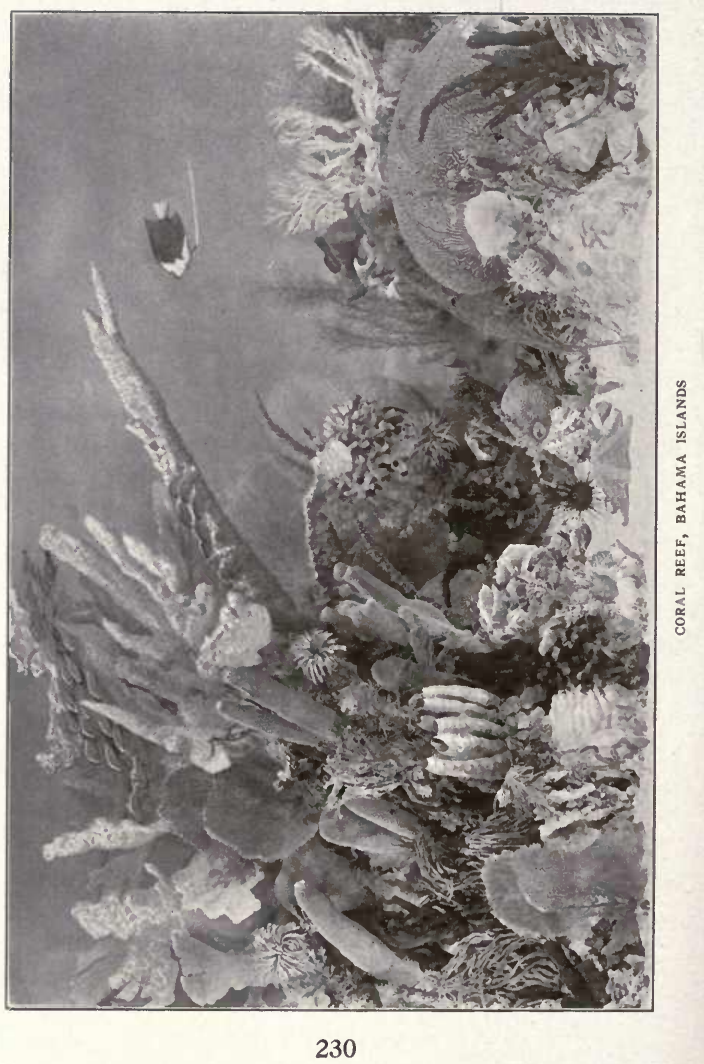




\section{THE BROOKLYN MUSEUM}

wall of this room is an exhibit illustrating the variation in nature which may be brought about by different conditions.

Variation with Sex or Season is shown by a group of ruffs, and a fine series of great horned owls, representing a wide area, illustrates well the varieties that may occur in one species with varied geographic range.

Variation Under Domestication is illustrated by an exhibit on the east wall, showing the domesticated fowl as evolved from the jungle fowl of India, and on the same side of the room the various means by which different animals have been able to survive in the struggle for existence, e.g., by endurance, numbers, armor, concealment and warning or protective coloration, are indicated.

Albinism, Melanism and other color phases of animals are shown in the passage to the east of this room; and, opposite these, Adaptation to Environment is well illustrated by the snowy arctic owl, desert and cave animals and, around the corner in the next hall, by color changes in the demon stinger fish.

The Hall of Vertebrates (Room 4 on plan), leading out of Room 5 toward the west, contains exhibits of all the important groups of backboned animals from fish to man, arranged so that, by passing up the left or south side of the room and down the right or north side, the animals are considered in evolutionary sequence; also each group or series is arranged so that the lower or simpler forms appear at the left, and therefore the exhibits should be studied from left to right. 
The first floor case on the left contains an introductory series of fishes, preceded by the lancelets, the lowest of the backboned animals, having neither skull, jaws nor brain and in which the skeleton is represented only by a slender longitudinal cord. The hagfish, lamprey and other intermediate types are also shown, and, on the right, examples of a typical bony fish, showing skeletal characteristics, and a model of the anatomy.

Various tropical fishes are exhibited on the other side of this case, and, in cases behind and in front of it, going up the hall, examples of the various orders of fishes are shown, together with models of many of their extinct relatives. A diagram, on the right-hand end of the first upright floor case, shows the various deep-sea fishes and the depths at which they live. Models of deep-sea fishes are shown in a near-by case; the phosphorescent organs possessed by some species are their most striking characteristics.

A model of the great white shark, or man-eater, is exhibited on the north wall, and plates from the United States Fish Commission series, representing the important food and game fishes of North America, are also shown.

Following the fishes, the amphibians, intermediate between water and land animals, are exhibited in the next floor case, and here an enlarged model of the frog's anatomy, with skeleton, indicates the main structural differences involved in the change of conditions. Salamanders, toads and other representative amphibians are here exhibited, and, on the other side of the same case, a mounted 


\section{THE BROOKLYN MUSEUM}

American alligator and skull of a crocodile assist in making clear the difference between crocodiles and alligators, emphasized elsewhere.

Facing these, on the north wall, is an exhibit illustrating the characteristics of the Class Reptilia, which, with many descriptive labels, provides the visitor with a comprehensive view of general and special points of structure of this class of animals.

On the wall behind this exhibit are maps showing the distribution of dangerous snakes and of amphibians, and a painting at the side shows the color changes of the common chamæleon.

Proceeding up the hall, exhibits of crocodiles, snakes and lizards, including the more important and interesting types of these animals, among which may be mentioned the rare tuatara from New Zealand, a primitive lizard-like reptile belonging to an order of which every other family is now extinct. Models of the extinct Plesiosaurus, a marine reptile with crocodilian characteristics, of the Stegosaurus, an extinct armored dinosaur of the Jurassic period, and of an Ichthyosaur, a fish-like lizard representing a group of reptiles abundant in Triassic times, help to relate the existing species of reptiles with those of ages of the past. The Ichthyosaurs were adapted to life in the sea, having four paddles and a powerful tail for swimming.

Typical examples of harmless and poisonous snakes are shown and the lizards are especially well represented; a study collection of these is available for students and in- 


\section{THE BROOKLYN MUSEUM}

cludes many species of snakes, lizards, iguana, horned toad, running lizards, blue and green lizards of Europe and the skink of Egypt, as well as the Congo monitor, the Gila monster and others.

A representative collection of land and fresh-water turtles, with skeletons, models and maps of distribution, appears next. The specimens include the rare matamata of South America, giant tortoise of the Galapagos Islands and examples of the leather-back, hawksbill and other important turtles. A pictorial representation shows the extinct giant sea turtle found in the Cretaceous deposits of South Dakota. In all these exhibits the inclusion of skeletons with the mounted specimens makes possible a clearer understanding of the animals under consideration.

Birds, following the reptiles in order of evolution, follow them also in order of exhibition, and on the north wall at this point appears a reproduction of the reptile-like extinct bird Archoeopteryx, whose fossil remains in the Solenhofen slates have proved so important a link between reptilian and avian types.

The synoptic series of birds follows, and the case at the right contains the large ostrich-like birds, including the ostrich, cassowary, rhea and emu, the rare and almost extinct Apteryx of New Zealand and the tinamou of South America, the latter interesting because it seems to provide a connecting link between the ostrich-like birds and birds in general. Hawks, gulls, loons, penguins and other birds shown in this case form an interesting introductory exhibit. 


\section{THE BROOKLYN MUSEUM}

The cranes and curlews, ducks and geese and their related families are next seen, followed by the pelicans, cormorants, bitterns, herons, storks and ibises, and in a floor case is a group of king penguins from Kerguelen Island in the Indian Ocean. There are seventeen living species of these birds, of which the emperor penguin is the largest. They are incapable of flight, awkward on land but at home in the water.

On the north wall at this point, a deer skeleton finds a place, for lack of convenient space elsewhere, following which the birds of prey and those of the pheasant and pigeon families occupy the floor cases. Here the curious nesting habits of the greater hornbill of India are indicated.

To the right of this case are the woodpeckers, kingfishers and parrots, a portion of a tree trunk inset with acorns by the California woodpecker, and the curious wing coloration of the African plantain-eater, which washes out with rain, being especially interesting items.

The floor case opposite this exhibit contains the peacock, a native of India, and the Argus and other pheasants.

The perching birds (Order Passeres) are exhibited in cases to the west and south. This, by far the largest order of existing birds, contains several thousand species, ranging from the small and modest wren to the gorgeous birds of paradise. The lyre-bird of New South Wales, the rare Peruvian cock-of-the-rock and many brilliant and interesting specimens from India, China, South America and elsewhere provide material for a comprehensive purview of the 


\section{THE BROOKLYN MUSEUM}

order; the birds of paradise, twelve species, are placed in a separate case on the west wall. Nests of South American birds, showing colonies and various styles of bird architecture, are exhibited.

(On the other side of the vertebrate hall are the marsupials and other mammals up to man. It is well, however, to visit first the exhibit of birds of Long Island, contained in Room 1 on this floor, and the exhibit of animals of Long Island in Room 3 adjoining.)

The birds of Long Island are arranged in a series of cases and habitat groups around the walls of Room 1, and the aim of this collection and that in the adjoining room is to present eventually a complete series of the vertebrate fauna of this area. The bird collection is well on the way to completion and contains many forms notable because of their rarity. Among the habitat groups, that of the marsh hawk, a small bird feeding mainly on frogs, snakes and small animals, and that of the black-backed gull, a sea-coast breeder of the north but found in the autumn as far south as Virginia, are notably interesting. Pictorial representations of the heath hen, Labrador duck and great auk, birds of Long Island which have become extinct during the last century, are shown on the west wall of this room.

The mural paintings on the walls of this room represent typical shore and inland scenery of Long Island and help materially to relate the bird exhibits with their habitats.

Many of the perching birds of Long Island are exhibited in the corridor between Rooms 1 and 3, and here also a large map of the island, colored to represent contour and 


\section{THE BROOKLYN MUSEUM}

geological formations, may be seen. Over the entry between Rooms 2 and 3 is a model of the common porpoise.

The animals of Long Island, exhibited in Room 3, include mammals, insects and mollusks, fishes and reptiles being as yet unrepresented here.

A series of small mammals, including squirrel, woodchuck, opossum, rabbit, skunk, weasel and other wellknown forms, occupies a case on the west wall. A mounted specimen of the white-tailed Virginia deer is seen in the center floor case, north of which is a small habitat group of chipmunks, which completes the mammal exhibit.

Under the window a meadow-lark is shown with nest and young, on either side of which two cabinet cases contain respectively the butterflies and moths and the beetles of Long Island.

Exhibits illustrating the life histories of North American butterflies and moths, showing the various stages through which a moth or butterfly passes from egg to adult, together with its principal food plants and enemies, are shown at the other end of this room on the east and west walls.

On the west wall an exhibit of the brown-tailed and gypsy moths, showing the destruction caused by them, is intended to enable the public to recognize these pests.

The salt-water, fresh-water and land shells of Long lsland are exhibited in two large cases in the center of this room.

Returning to the Vertebrate Hall, the systematic series of mammals follows the exhibit of perching birds, beginning with the large case on the left (northwest) side of the hall, 


\section{THE BROOKLYN MUSEUM}

containing the monotremes and marsupials. Examples of all living families of each are exhibited.

The Monotremata, the lowest order of mammals, possess both reptilian and bird-like characteristics. Two living representatives are known, both nearly extinct: the Echidna, a spiny, egg-laying mammal, and the duck-billed Platypus, a beaked creature living in burrows. Examples of each are exhibited, as well as an egg of the Echidna, and a skeleton of the same showing the reptilian characters.

The Marsupialia, pouched mammals, are represented by the opossum, the rare mole marsupial of South Australia, and the Tasmanian "wolf," or Thylacine, in reality not a wolf but a distant relative of the opossum. This powerful creature, once abundant in Tasmania, has been hunted, on account of its sheep-killing proclivities, until it is nearly extinct.

Other marsupials shown are the bandicoot, hare wallaby, Bennett's wallaby, Venezuelan woolly opossum, carrying its young on its back, the banded anteater, the flying, common and spotted phalangers and the red and gray kangaroos. The skeleton of a kangaroo (skull and pelvis) and a model of the brain, showing its small size and smoothness, together with detailed labels giving characteristics of the Order Marsupialia, complete this introduction to the mammalian series.

Proceeding along the left side of the hall, the Order Edentata next appears: mammals either toothless or without front teeth. The sloths, anteaters and armadillos are the 


\section{THE BROOKLYN MUSEUM}

principal existing forms of the order, which is a very old one, at one time numerous and comprising many gigantic forms now extinct. The great anteater, or antbear, of Brazil, two mounted specimens and a skeleton of which are exhibited, is one of the largest of existing edentates. The pangolin, or scaly anteater of the Old World, with overlapping, horny scales, the four-toed anteater, the yellow tamandua and the three-toed and two-toed sloths are shown here, as well as the six- and nine-banded armadillos and the aard vark, or antbear, of South Africa.

In the same case are exhibited the Rodents or gnawing animals. These comprise the largest order of existing mammals, and there are many different families and genera. Among the specimens are squirrels and chipmunks, the South American capybara, largest of living rodents, the paca of South America, the pocket gopher, named from the pockets in its cheeks, the spermophile, muskrat, porcupine, the vischacha of South America, and others.

On the north wall at this point, horns of the greater kudu, a rare African antelope, are exhibited, below which are some fine examples of scrimshaw work on the teeth of whales, an art practised by sailors in the days of whale fishing. A walrus tusk in the same case is similarly engraved by Indians of the Northwest Coast. On the same wall just beyond is an exhibit of tusks of the mammoth, with ancient figures of this extinct relative of the elephant, also teeth of the mastodon and of the modern elephant. 


\section{THE BROOKLYN MUSEUM}

The model of a skeleton of Dinoceras, a large extinct mammal of Eocene times, related to the rhinoceros, and a sketch representing the restored animal appear in a case beneath the window, facing a mounted specimen of the sea leopard, a large antarctic seal.

The hoofed animals, farther down on the left, are represented by the Rocky Mountain sheep, the Spanish ibex, a fully grown llama from South America with a heavy coat of hair, a specimen of Grant's zebra, the head of an Alaskan caribou and a small model of the extinct Irish elk, the largest of the deer family. A model of Tinoceras, related to the elephant and rhinoceros, is also shown here. The habitat groups of hoofed animals are exhibited in the Central Hall.

Proceeding down the hall, a complete giraffe skeleton occupies a position on the north wall, facing an exhibit of Pribilof foxes from the islands of St. George and St. Paul in Bering Sea. These animals, usually known as blue foxes, change their coats to white in winter, in the northern parts of their range. Specimens of both colors are exhibited, and a photograph of these animals at home is shown on the north wall near-by.

A series of aquatic mammals, including dolphins, whales, seals and sea elephants, the latter a species of earless seals, is next exhibited, and, related to these exhibits, the skeleton of a manatee or sea cow, which appears above the hoofed animals in the previous case, and the skeleton of the sperm whale, suspended in the center of the hall, should be examined. A map showing the distribution of the sperm whale 


\section{THE BROOKLYN MUSEUM}

is exhibited on the north wall, together with an account of the animal. A small model of the sulphurbottom or blue whale gives a good idea of this creature, the largest animal that ever lived.

The wolves, foxes and members of the dog family occupy the next case, represented by the Alaskan wolf, arctic fox, Eskimo dog, raccoon dog, swift fox and a family of timber wolves. A floor case near-by shows a group of red foxes and young in their natural habitat and south of these another habitat group shows the common eastern skunk with nest and young in typical surroundings. Various small carnivorous animals, including the palm cat of Borneo, civet cat, wolverene, weasel, otter, Himalayan panda and Brazilian coati-mundi, appear in the next large case, and here also raccoons, black bear and a skeleton of the polar bear are shown.

The study of the beasts of prey in the next exhibit is made more interesting by a pictorial representation of the Mesonyx, a typical example of the Creodonts or extinct primitive beasts of prey from which the existing types have been derived. Some rare specimens are exhibited, including the clouded tiger; ocelot, or tiger cat, and the snow leopard, or ounce. The jaguar leopard and wild cat are also exhibited, and a list of books of reference may be consulted on the adjacent wall.

Insect-eating mammals are particularly well represented in the Museum by a group in the next floor case. The common mole, which feeds upon underground insects; the star- 


\section{THE BROOKLYN MUSEUM}

nosed mole, so called because of the curious star-like formation on the end of its snout; the African or golden mole, rare in collections; the common shrew; the water shrew of western Africa, which can swim and feeds upon water beetles and crustaceans; the squirrel shrew of Asia which feeds on insects and fruit; the African jumping shrew; the curious solenodon, a little-known animal confined to the islands of Cuba, Santo Domingo and Haiti; the hedgehog of Europe, whose bristly spines enable it to turn into a prickly ball in the presence of danger, and the tenrec, or Madagascar hedgehog, complete a representative series of the Insectivora.

Members of the bat family occupy other side of case.

The lemurs, in a case to the north, belong to the lowest division of the Order Primates, which contains also the monkeys, apes and man. The specimens shown include the gray lemur, smallest of the true lemurs, the ring-tailed lemur, one of the most beautiful, and the ruffed lemur, black-headed lemur, crown lemur, mongoose lemur and the aye-aye, a rare relative of the lemurs which resembles a squirrel.

In the large Primate case, which now faces the visitor at the end of the hall, may be seen monkeys of the Old and New Worlds, the anthropoid apes and a model of an aboriginal Australian, to represent man.

The monkeys of the New World, shown at the left of the case, differ remarkably from those of the Old World, one important point of difference being the prehensile tails, by 


\section{THE BROOKLYN MUSEUM}

which the New World monkeys can cling and climb. Marmosets, or squirrel monkeys, howlers, the capuchin, or hooded monkey, and others of the New World are shown.

The Old World monkeys include the rare Entellus monkey, one of the sacred monkeys of India, the horse-tailed monkey and the Abyssinian baboon. The anthropoid apes are represented by the orang-utan and the chimpanzee. 'The gorilla is depicted on the wall on the left, accompanied by a map showing the distribution of the Order Primates.

The Central Hall, reached through Room 5, contains the large animal groups, the eggs of North American birds and certain mineralogical exhibits.

Immediately facing the entry from Room 5 is a group of South Atlantic petrels, so planned that the observer appears to look over the side of a ship at sea and watch the sea birds skimming the water and careening in the air around the boat.

Facing this group, on each side of the entrance, are two window groups of South American birds and nests. One of the interesting points about the group on the right, showing a colony of Venezuelan orioles or hang-nests, is the fact that these birds seem always to choose the vicinity of wasps for their colonies, and the group shows the bird and wasp nests pendent from the same branch. The left-hand group shows a cave in the mountains of Trinidad, the home of the curious and rare guacharo, or oil bird, whose nest is plastered against the sides of the cave. The young birds are shown in every stage of growth. This bird belongs to a 


\section{THE BROOKLYN MUSEUM}

family related to the goatsuckers, but it lives exclusively on fruits, instead of on insects as do the true goatsuckers. The name "oil bird" is due to the abundant fat of the young birds, from which the natives prepare a colorless oil used instead of butter.

Continuing to the left, a group of beavers is exhibited next to the petrel group.

Eggs of North American birds are seen in a large case on the west wall, facing the beavers, and other cases of these eggs are ranged at intervals around this hall. Above the egg exhibit at this point, an interesting example of the skin of a fur seal illustrates the various stages in the preparation of the fur for use.

Still keeping to the left, a large window group showing the birds of the Pribilof Islands appears facing the visitor on the south wall. These rocky islands in Bering Sea are the home of myriads of sea birds (murres, auks, puffins, cormorants, gulls and others) which nest on the rocks or in burrows among them. About fifty specimens (representing ten species) are shown against a natural background of rock and sea.

To the right of this group, over the doorway, are the horns of a Spanish bull, South African steer and South American steer.

Continuing to the left around the hall, the first large floor group shows five specimens of Steller's sea lions, adults and young. These creatures of the North Pacific belong to the seal order, but their skins are not valuable for fur. 


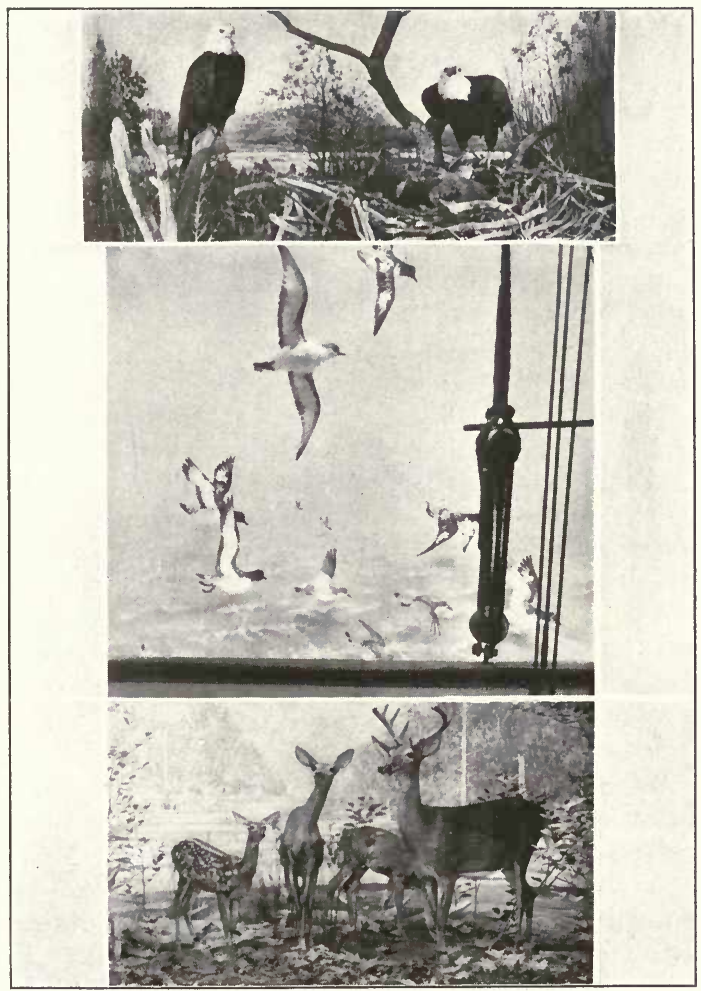

BALD EAGLE

CAPE PIGEONS AND WHAIE BIRDS

ADIRONDACK DEER 


\section{THE BROOKLYN MUSEUM}

The next window group on the right shows adults and young, nests and eggs of the South American bird known as the hoatzin. These birds live in trees near the water, and the young, never the adults, seek the water when pursued and can dive and swim skilfully. In the young birds, the wings are furnished with a pair of claws and are used as legs, so that the hoatzin seems to some extent to fill the gap between existing birds and the reptile-like fossil bird $\mathrm{Ar}$ chacopteryx, which also had clawed wings.

The group of musk-oxen from Ellesmere Land, consisting of an old male, female and a yearling male, in the next large case, shows the animals pawing away the snow to dig for dwarf willows which form their chief winter food. These animals are becoming scarce, owing to their use by arctic explorers as food for dog teams. Facing this group a fine old male polar bear is seen in his natural habitat.

The Atlantic walrus group shows an old female and young lying on the ice, while the head of a male appears above the water. These creatures, largest of the seal family, once lived in immense numbers on the northern coasts, but have been greatly reduced by relentless hunting for their oil and ivory, and in many places exterminated. The flesh, blubber, skin, tusks and other parts of the animal provided the Eskimo with most of the necessities of life.

A large window group, to the right from this point, shows an arid desert, the habitat of the Gila monster of Arizona and New Mexico, with several of these curious lizards basking in the sun. 


\section{THE BROOKLYN MUSEUM}

An exhibit which shows a typical portion of the Wyandotte Cave of Indiana, with the larger cave animals which inhabit it, appears next on the right wall. The comparison of this exhibit with that in Room 5, which shows the extreme modifications in color and eye atrophy, occurring as a result of continuously dark and limited environment, will prove interesting. (Blindness or absence of eyes is not characteristic of cave animals, except in special cases.)

Still keeping to the left around the hall, a large iron meteorite from Arizona is seen on the right, near a small model of the American mastodon in a case on the wall, above which to the right is a mounted hippopotamus head.

The large window case here shows the golden eagle with nest and young, and to the left, flanking the entrance to the eastern galleries, are large sections of fossil trees from the National Forest Reserve in Arizona. Smaller sections of these trees are shown at the extreme left.

The skeleton of a full-grown male American mastodon occupies the central floor space at this point.

A large glacial pot-hole, formed in a piece of rock in Maine during the time when that portion of the continent was in the grip of the Ice Age, appears below the mastodon model on the right, and a mounted African eland is exhibited in an alcove near-by. Around the walls of this alcove, various forms and uses of the mineral asbestos are shown.

At the left of the hall at this point, a striking group of golden howler monkeys from South America shows adults and young in a tree-top habitat. 


\section{THE BROOKLYN MUSEUM}

A special exhibit of birds' eggs in the floor case at this corner of the hall emphasizes the more important facts to be discovered from a study of birds' eggs, such as the variation in size, color, markings, number of eggs in a clutch and relation between size of bird and egg. The egg of the Epyornis, the large extinct bird related to the ostrich, is shown. This exhibit is intended to be studied in connection with the exhibits of eggs of North American birds shown in the series of cases in this hall.

One of the most interesting exhibits in the Museum faces the visitor at the right (northeast) corner of the hall and illustrates the mechanism of flight in animals and the differentiation between gliding and flight proper. Skeletons of fore limbs, showing modifications for flight, deviation from the generalized type and relations to the human arm, include those of monkeys, opossum, bat, ostrich, pterodactyl or flying reptile and the reptile-like bird Archocopteryx.

To the left, some examples of reversion to type, as shown by the domestic fowl, may be properly compared with the exhibit in Room 5, illustrating Variation under Domestication.

Proceeding up the north side of the hall, a large group of Rocky Mountain goats, comprising the old male, two females and two young, is exhibited in the next floor case. This so-called goat is an antelope related to the Asiatic goat-antelope, inhabiting almost inaccessible slopes of high mountains.

Specimens of the eastern moose, the largest existing 


\section{THE BROOKLYN MUSEUM}

member of the deer family, comprise the next group; these animals, taken at New Brunswick, are shown in an autumn scene characteristic of their natural habitat.

To the left is a group of American black bears and young, and just ahead a large group of American bison shows an old bull, an old cow and a young cow and calf.

Under the window are cases exhibiting rocks of the Silurian, Upper Cambrian and Cambrian geological formations with the fossils found in them, and on the wall a vertical section shows the rock strata of New York State.

A temporary installation, showing skeletons of the sea lion, swordfish and other marine animals, occupies the west wall at this end of the hall, and at the left a large group of fur seals from St. Paul's Island in Bering Sea brings the visitor again to the point at which he began a survey of this section of the exhibits.

There yet remain exhibits of minerals, invertebrates and plants in the eastern galleries, and, returning to the entrance to these galleries on the opposite side of the central section, the first corridor (Room 6 on plan) contains the systematic series of minerals.

In the center of the second alcove, an exhibit of ornamental minerals shows polished agates, quartz, azurite and other specimens possessing beauty and value.

The large window group facing the mineral alcove in this corridor shows the Virginia white-tailed deer, the most abundant and most generally distributed of American deer, in a summer woodland scene, and just beyond it a small- 


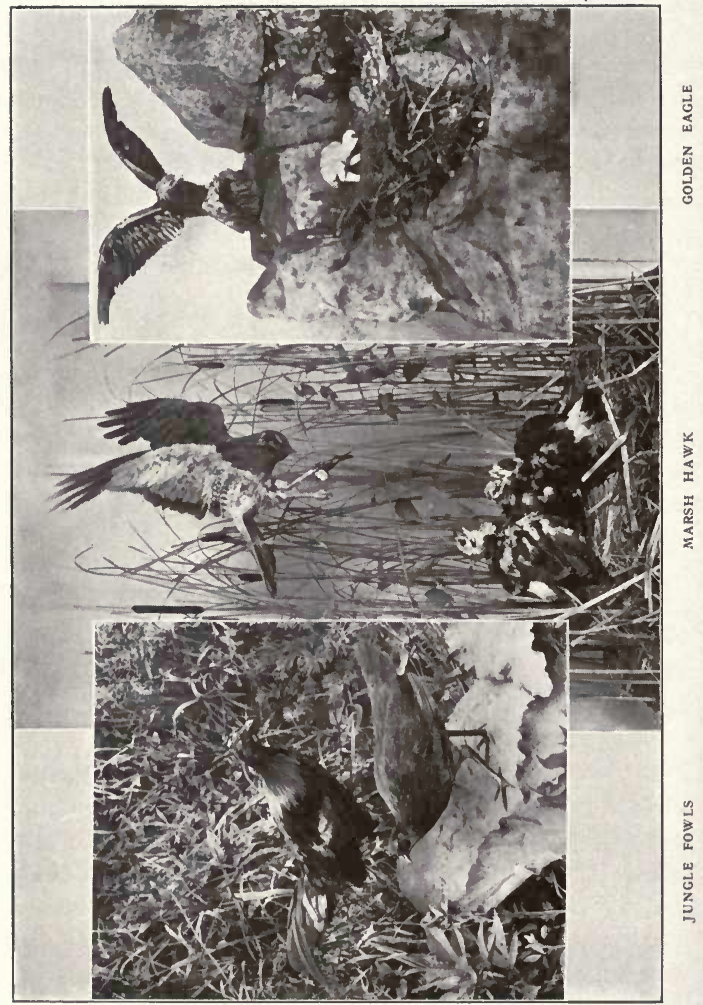




\section{THE BROOKLYN MUSEUM}

scale model, "Woodland Tragedy," represents two deer with inextricably locked antlers, a realistic interpretation of the facts being indicated by the actual pair of skulls with locked antlers shown on the adjacent wall. This fatal ending to an encounter of fighting bucks in the mating season is not uncommon.

Proceeding eastward, the Hall of Invertebrates (Room 7 on plan) is next entered, where the sponges and corals, worms, mollusks, crustaceans and other types of animals lacking a backbone are exhibited.

The sponges and corals, from all parts of the world, are systematically arranged in wall cases on the west, north and south sides of the hall, and in various floor cases special groupings have been made of sponges and corals of particular beauty or interest or of unusual size.

Specimens of the Protozoa, or one-celled animals, the simplest forms of animal life, are shown in the first floor case on the left (north) side of the hall, by the aid of microscopes, and also by enlarged glass models. The sponges are the simplest forms of animals whose bodies consist of more than one cell, for the cells, although arranged in two layers, act each independently. Varieties of lime sponges, glass or silicious sponges and horny sponges are shown, as well as fresh-water, deep-sea and boring sponges, and sponge spicules under the microscope.

Models of coral, showing the anatomy of the polyps and their relation to one another, are seen in the second floor case on the left, which contains also models of the fresh- 


\section{THE BROOKLYN MUSEUM}

water polyp hydra and other related forms. In the adjacent wall cases, specimens of mushroom, staghorn and brain coral and other forms are shown. A very large specimen of brain coral from the Bahamas and a specimen of staghorn coral, one of the largest pieces of branching coral ever collected, are exhibited in floor cases in the center of the hall.

Among the mural paintings in this hall, representing some of the more striking invertebrates as they appear in life, is one depicting a coral reef in a tropical sea, and on the south wall in the center of the hall a large window group shows a coral reef close at hand and the animals that frequent it. Other mural paintings show an octopus at home, the formation of a mangrove swamp and other typical shore scenes of the Atlantic coast. Proceeding down the left side of the hall, the starfish and sea urchin families occupy the next case, and the development and anatomy of starfishes and sea urchins are illustrated by drawings, dissections, models and specimens of various ages. Abnormal specimens and specimens showing regeneration of rays in a starfish also are shown. The various types of sea urchins occupy the eastern side of the case. The worms in the next cases include the serpulid worm of the sea, the horsehair worm and a model enlarged and dissected; the branchiopods, related to both worms and mollusks, are shown here.

Crustaceans, in the next case, are represented by some one hundred species, including the crayfish with an enlarged model of dissection to show the anatomy, and a section of mud from a river bank showing a crayfish group at 


\section{THE BROOKLYN MUSEUM}

home, together with crabs, lobsters, shrimps, barnacles, horseshoe crabs and others. In the wall case at this point, the giant spider crab and the locust lobster of Japan, the largest species of living crustaceans, are shown.

The systematic series of shells, which includes characteristic examples of the principal divisions of mollusks and gives a general impression and synopsis of this group of animals, is arranged in two floor cases on the right (southern) side of the hall at this (western) end. The largest specimens are in the upper part of the case, and the extensive study collections are arranged systematically in drawers below. Fine specimens of the nautilus and argonaut, representing the higher mollusks, may be seen, also the paper nautilus of Japan; a particularly interesting specimen is the naked mollusk from Naples, which appears to have no shell because the shell is internal.

An exhibit of land snails and of shells from Lake Tanganyika occupies a position in the systematic series of shells and shows specimens of the eggs of marine mollusks.

The ship-boring bivalve teredo and its work in destroying ship bottoms are exhibited in the case next on the east; sections of wood show the damage done and method of work, and photographs show the anatomy of the animal. Other boring mollusks are exhibited here also, and in the upper part of the case are habitat groups of the edible snails of southern Europe. The common vineyard snail is extensively used for food and snail farms are operated to produce it in quantity. 


\section{THE BROOKLYN MUSEUM}

An exhibit of pearl shells from the pearl fisheries of Ceylon, showing pearl oysters in various stages and the process of abstracting pearls from the shells, is installed in the eastern side of this case.

The marine animals of the coast of Long Island and New England, from high tide to a depth of 7,200 feet, form an interesting exhibit in the last floor case on this side. Among the specimens may be mentioned the oyster drill, showing the drilled shells, egg cocoons and stages of growth of the animal, and mounted specimens of the pipefish, sand flea and other shore creatures. Models of the octopus and squid occupy the last wall case at this end of the hall and should be compared with the giant octopus and squid suspended from the center ceiling and the marine painting above.

Passing into the Insect Hall (Room 8 on plan), a chart on the left of the entry traces the phylogeny or lines of descent of the arthropods, showing their relationships to the worms. Facing this, another chart shows an introductory series of insects, noting typical examples of the principal families. An exhibit of household insects, such as the flour moth, carpet beetle, leather beetle, ant and other undesirable inmates of the dwelling, is shown on the west wall of this room, below which are six cases containing the systematic collection of beetles. Facing these, the true bugs are exhibited in the six lower cases, and above them is a series illustrating variation in color and form, protective mimicry, vestigial and rudimentary organs in insects, various phases of biological and economic interest and geographical variation. 


\section{THE BROOKLYN MUSEUM}

Two groups, showing the tent caterpillar and army worm and their bird enemies, occupy the central floor space on the north side of this room. The insects which produce these injurious larvæ lay their eggs on trees and vegetation and the caterpillars do immense damage. Two other injurious insects, the cotton-boll weevil and the bark louse, are exhibited in the southern central floor case, their development and effect being also illustrated.

Nests of ants infesting acacia and other trees, and combs of the honey bee in the branches of a tree, the latter representing a return to ancient habits, are exhibited in this same floor case, together with various species of wasps and their nests.

Another striking exhibit of wasps and wasps' nests, including some interesting South American species, is shown in a large case on the north wall. The systematic collection of butterflies is displayed on the east wall, and, facing them, the Neuroptera or nerve-winged insects and the roaches, mantids, grasshoppers, katydids and others.

The Plant Hall (Room 9 on plan) leads out of the Insect Hall on the east. An exhibit of the mushrooms and toadstools which grow in the neighborhood of New York City is shown here. A habitat group of plants and animals of the desert is in course of preparation and will shortly be opened to the public. It represents an Arizona desert scene, in which giant cacti, sage brush and other typical desert plants are shown, together with pronghorned antelope and desert birds and reptiles. 


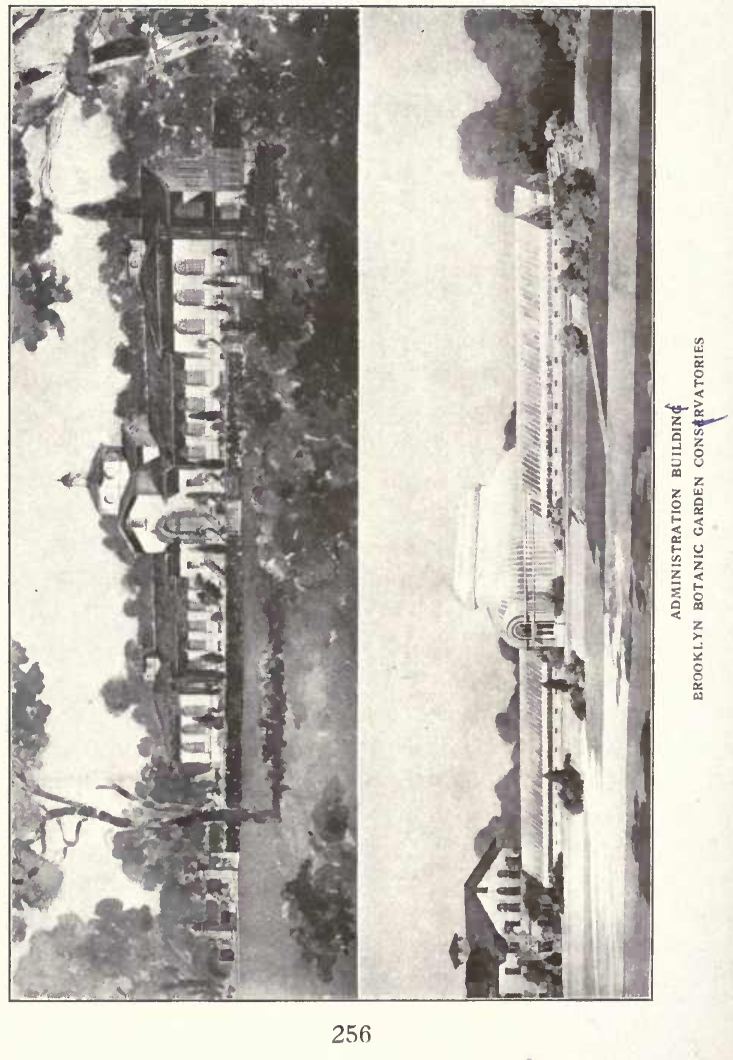




\section{THE BROOKLYN BOTANIC GARDEN}

The Brooklyn Botanic Garden was established in 1910 as a Department of the Brooklyn Institute of Arts and Sciences. Its object is the advancement and diffusion of a knowledge and love of plants.

It is located just east of Prospect Park, south of Eastern Parkway, and comprises approximately forty-eight acres, situated in the very heart of the Borough of Brooklyn.

The Garden is open free to the public daily from 8 A.M. until dark; on Sundays and holidays it opens at 10 A.M.

The entrances are on Flatbush Avenue, near Malbone Street and near Mt. Prospect Reservoir; on Washington Avenue, south of Eastern Parkway and near Malbone Street; on Eastern Parkway, west of the Brooklyn Museum. The Laboratory and Administration Building is on Washington Avenue, with entrances opposite Crown Street, as well as from the Garden, and may be reached by Flatbush Avenue surface cars to Malbone Street; Franklin Avenue and Lorimer Street surface cars to Washington Avenue; St. John's Place surface cars to Sterling Place; Ninth Avenue, Sixteenth Avenue, Union Street, Greenpoint, and Smith Street surface cars to Prospect Park Plaza and Union Street; and Brighton Beach elevated to Consumers' Park 


\section{THE BROOKLYN BOTANIC GARDEN}

station. (The elevated train stops only when the conductor is notified in advance.) The new subway lines will have stations at the Eastern Parkway entrance and at Malbone Street.

A docent will meet parties by appointment and conduct them through the Garden. This service is free to members of the Botanic Garden and to teachers with classes; to others a nominal charge of twenty-five cents an hour for parties of fewer than three, and ten cents a person an hour for parties of three or more.

The Brooklyn Botanic Garden is supported in part by municipal appropriations and in part by private funds, including income from endowment, membership dues and special contributions. Its articulation with the City is through the Department of Parks. The City owns the land devoted to Garden purposes, builds, lights and heats the buildings and keeps them in repair and includes in its annual tax budget an appropriation for maintenance. A portion of the cost of the present buildings was met from private funds.

By the terms of a written agreement, dated August 17, 1914, between the City of New York and the Brooklyn Institute, touching the Botanic Garden, all plants must be purchased by private funds. In addition to this, it is the practice of the Garden to purchase all books for the $\mathrm{Li}$ brary, all specimens for the Herbarium, all lantern slides, and other necessities, and to pay certain salaries, with private funds. 


\section{THE BROOKLYN BOTANIC GARDEN}

Special privileges are granted to teachers and classes from local schools; and members of the Garden, in consideration of their payment of dues, enjoy certain advantages not extended to others.

Membership: The Brooklyn Institute of Arts and Sciences is organized in three main departments: 1. The Department of Education; 2. The Museums; 3. The Botanic Garden. Any of the following seven classes of membership may be taken out through the Botanic Garden: 1 . Annual member, $\$ 10 ; 2$. Sustaining member, $\$ 25 ; 3$. Life member, $\$ 500 ; 4$. Permanent member, $\$ 2,500 ; 5$. Donor, $\$ 10,000 ; 6$. Patron, $\$ 25,000 ; 7$. Benefactor, $\$ 100,000$. Sustaining members are annual members with full privileges in all three departments. Membership in classes 2-7 may be taken out in any department, but carries full privileges in all three departments.

The Garden is organized in eight departments: Administration, Graduate Study and Research, Public Instruction, Plantations and Conservatories, Laboratories, Library, Herbarium and Publications.

\section{PLANTATIONS}

"Flowers of all hue, and without thorn the rose."

1. Systematic Section, in which hardy herbaceous plants, exclusive of local flora, are arranged in beds according to their natural relationships. This section also includes shrubs (Fruticetum) and trees (Arboretum). 


\section{THE BROOKLYN BOTANIC GARDEN}

2. Local Flora Section, which is one of the most interesting parts of the Garden, for here are to be found, fully labeled, nearly 1,000 species of herbaceous and woody plants which grow without cultivation within a radius of 100 miles of New York City.

3. Morphological Section, illustrating external plant anatomy or plant structure and furnishing an opportunity for comparative study of plant organs.

4. Ecological Section, illustrating the adjustment of plants to their surroundings.

5. Evolution Section, illustrating various interesting facts of variation, inheritance, artificial and natural selection, struggle for existence, survival of the fittest and plant breeding.

6. Economic Section, in which are found plants which furnish foods and condiments, those which are medicinal or poisonous, and fiber plants. To the children and many adults living in a large city, this is one of the most instructive parts of the Garden, for an exhibit of this kind affords them their only opportunity of seeing the commonest food, medicinal and fiber plants as they grow.

7. Weed Section, showing the characters of weeds.

8. Formal Garden Section: Japanese Garden, Rock Garden, Esplanade, Laboratory and Conservatory plazas.

Among these sections, the Japanese Garden deserves special attention. Opened in June, 1915, it is becoming more attractive as the flowering cherry, plum and apple 


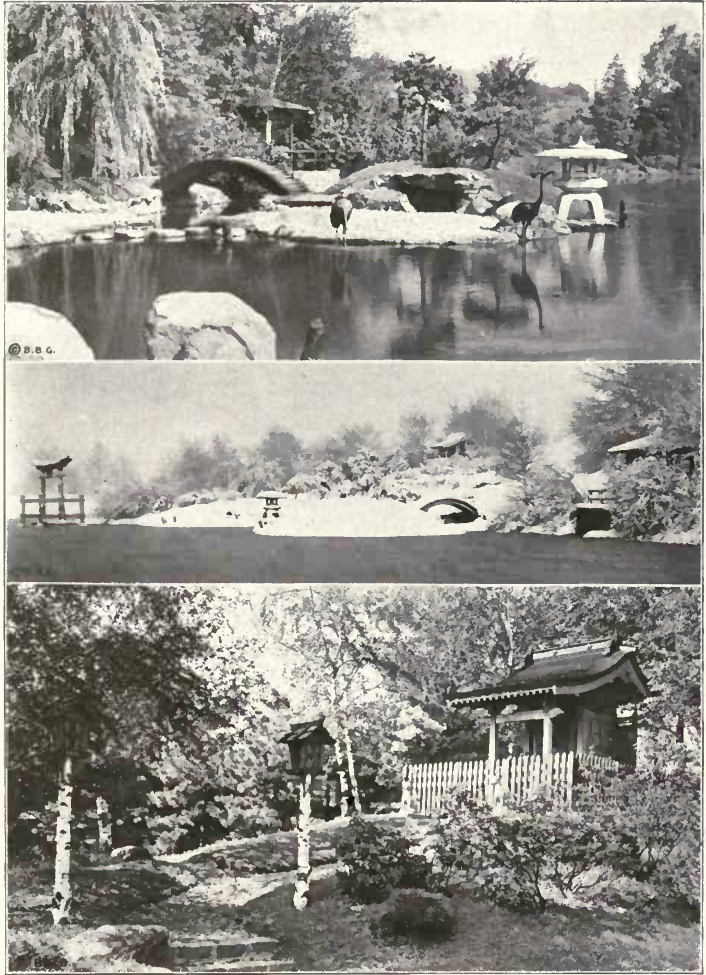

VIEWS IN THE JAPANESE GARDEN 


\section{THE BROOKLYN BOTANIC GARDEN}

trees and the azalea bushes become larger. This garden is most beautiful during the first part of May, when the wonderful Japanese flowers are at their height. It is not a flower garden, however, as is indicated by the following quotation from Mr. T. Shiota, the designer of the garden, in which he defines it as "the natural landscape idealized and pictured forth by real objects on the ground. Just as an artist sketches a scene on canvas, so the garden designer represents a beautiful object on the ground by the aid of pick and shovel, using trees, rocks, water and stones as nature uses them, but employing the principles of three separate arts-painting, sculpture, and architecture-to gain the effects we desire."

It is evident to the visitor that the idea has been well carried out here. On a site, especially favorable, including a portion of the shore of a small lake, are Inari shrines, gates, tea-house, moon-view house, wistaria arbor, bronze storks, picturesque drum bridge and stone lanterns, which combine with the plants and natural scenery to produce the general effect. An unusual and picturesque wooden structure known as a torii is situated in the lake. These structures are always placed before shrines and indicate the gate to a temple. The torii in the garden is modeled after the famous one at Miyajima, which stands in the sea and is the only torii in Japan so placed. 


\section{THE BROOKLYN BOTANIC GARDEN}

\section{THE CONSERVATORIES}

The Conservatories contain a selection of tropical and subtropical plants, with unusual emphasis upon those of economic importance. The Conservatories are open free to the public daily, from April 1 to September 30, 10 A.M. to $4: 30$ P.M., from October 1 to March 31, 10 A.M. to 4 P.M. The Library, open free to the public daily for reference, contains over 4,000 volumes and over 6,000 pamphlets on botany or closely related subjects. More than 250 current botanical periodicals are received. 


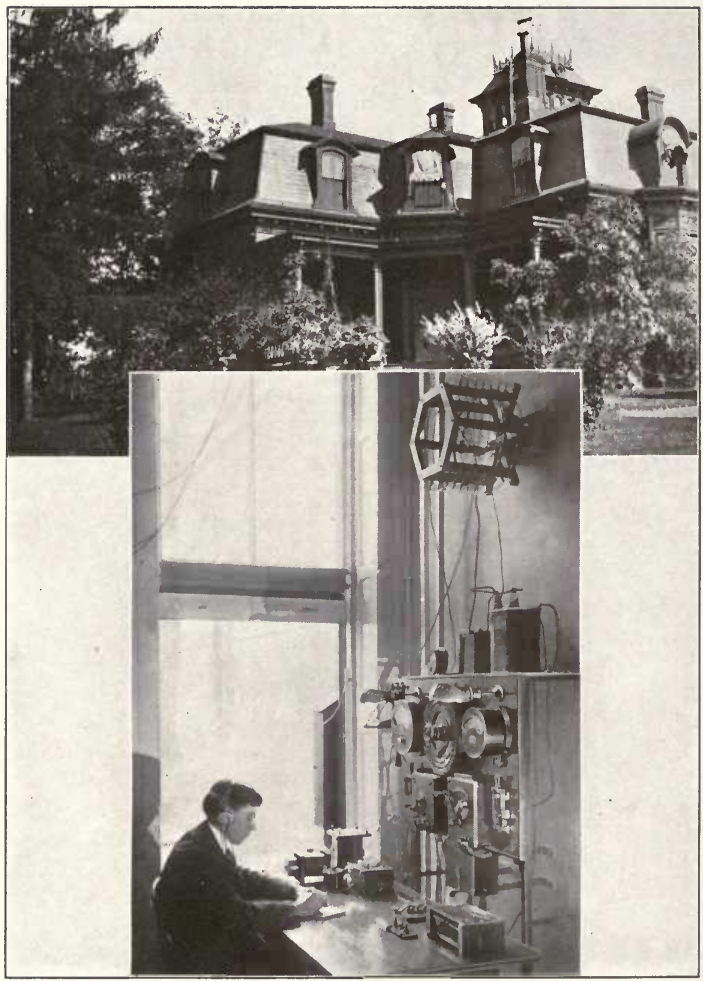

CHILDREN'S MUSEUM

WIRELESS ROOM 


\section{CHILDREN'S MUSEUM}

The Children's Museum was established as a branch museum of the Brooklyn Institute of Arts and Sciences in 1899. Its object is to interest children in nature and to offer encouragement and practical assistance to young people engaged in nature study.

To this end it exhibits a great variety of carefully selected and prepared specimens and models illustrative of the various departments of science; operates a Wireless Telegraph Station; maintains a Nature Reference Library of about 7,500 volumes; conducts free courses of illustrated lectures; lends natural history specimens to schools; supplies continuous docent service, and encourages the activities of children's nature clubs and societies.

The Museum occupies a well preserved mansion, owned by the City and leased by the Brooklyn Institute for an indefinite period. It is located in Bedford Park, near Brooklyn Avenue, between Prospect Place and Park Place, and may be reached from New York by subway to Atlantic Avenue station and thence by St. John's Place cars to Brooklyn Avenue, or from Brooklyn Bridge by Fulton Street or Bergen Street surface cars to Brooklyn Avenue, 


\section{CHILDREN'S MUSEUM}

or by Fulton Street elevated to Tompkins Avenue station, or from Williamsburg Bridge by Nostrand Avenue and Tompkins Avenue cars to Prospect Place.

The Museum is open free every day in the year: on week days from 9 A.M. to 5:30 P.M., on Sundays from 2 to 5:30 P.M.

Although managed and controlled by the Trustees of the Brooklyn Institute, the Museum is supported in part by optional annual grants from the City of New York and in part by the contributions of friends.

The Museum collections illustrate Zoölogy, Botany, Mineralogy and United States History.

\section{FIRST FLOOR}

"Our youth we can have but to-day,

We may always find time to grow old."

Berkeley.

In the north entrance hallway is a Botanical Exhibit consisting of a series of dissectible models, on a highly enlarged scale, showing successive stages in the germination and growth of common plants such as the bean and wheat. In the rooms at the right are the Birds of Prospect Park, grouped according to seasons into regular spring, summer, autumn and winter visitors; the occasional and rare visitors, and the permanent residents. At the south end of the building is the Zoölogical Type Collection, comprising a series of animals in an ascending scale from the lowest orders up 


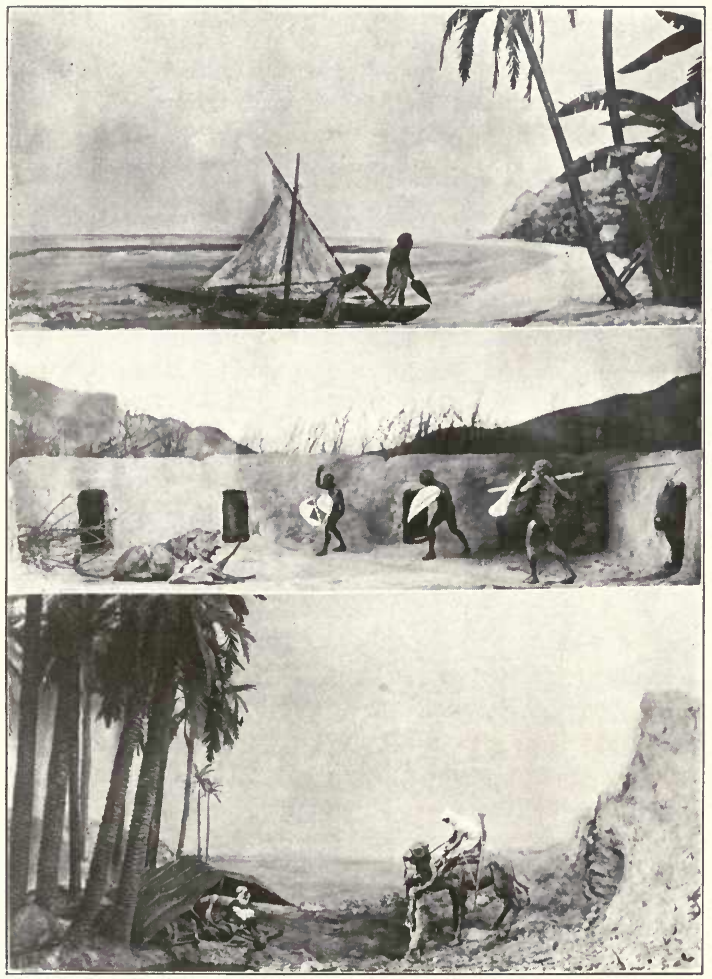

SOUTH PACIFIC ISLANDS

MASAI VILLAGE, BRITISH EAST AFRICA

SAHARA DESERT 
to man. Across the hall in the Insect Room one may see those specimens of insects found in the vicinity of New York City; life histories of insects including the silk worm; brilliant tropical species, and groups of specimens dealing with biological relationships. Adjoining is the Mineral Room with its showy models of gold and platinum nuggets; its models of historical diamonds; its displays of ornamental stones cut and polished; its uncut gems; its birthday stones, and the specimens of crystals, minerals and ores which open up the subject of Mineralogy in its broader aspects.

\section{SECOND FLOOR}

On this floor will be found the Room of Animal Homes, containing adult and young animals in or near their nests, the object of this collection being to emphasize the fact that many animals prepare nests and care for their young; the Shell Collection, containing many brightly colored tropical specimens; the Historical Room, special features of which are the series of miniature model groups depicting scenes in colonial life and illustrating important political, military and naval events in the history of the United States, and the Geography Room, where primitive races from the different zone belts of the world are portrayed, in miniature, occupying their natural habitats and engaged in their customary occupations. In this room a child may, within the space of an hour, make a world tour, beginning with a hunting trip in a Brazilian jungle, continuing with surf rid- 


\section{CHILDREN'S MUSEUM}

ing in the South Sea Islands, pausing among the Bedouin Arabs in an Oasis of the Sahara Desert, and ending with a walrus hunt among the Smith Sound Eskimo on the shores of Greenland by the light of the Aurora Borealis.

A special feature of the Museum is the "Busy Bee Room," where the children study natural history material with the aid of magnifying glasses and microscopes; preserve, classify and mount insects for their private collections; analyze, press and label plants which they have collected for their herbariums, and care for pet animals in which they are interested. In this room are also a hive of living bees and a number of balanced aquaria containing numerous forms of aquatic life. 


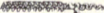

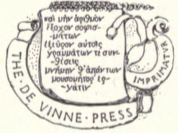





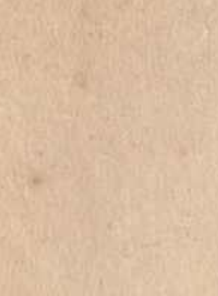
UC SOUTHERN REGIONAL LIBRARY FACILITY

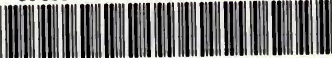
AA $000914080 \quad 7$ 
